University of Tennessee Health Science Center

UTHSC Digital Commons

\title{
Role of Dendritic Cells in Pathology of Respiratory Syncytial Virus Infection in Neonates
}

Bishwas Shrestha

University of Tennessee Health Science Center

Follow this and additional works at: https://dc.uthsc.edu/dissertations

Part of the Biological Phenomena, Cell Phenomena, and Immunity Commons, Medical Biochemistry Commons, Medical Cell Biology Commons, Medical Molecular Biology Commons, and the Virus Diseases Commons

\section{Recommended Citation}

Shrestha, Bishwas (http://orcid.org/0000-0002-6159-7686), "Role of Dendritic Cells in Pathology of Respiratory Syncytial Virus Infection in Neonates" (2017). Theses and Dissertations (ETD). Paper 433. http://dx.doi.org/10.21007/etd.cghs.2017.0575. 


\title{
Role of Dendritic Cells in Pathology of Respiratory Syncytial Virus Infection in Neonates
}

\begin{abstract}
Respiratory syncytial virus (RSV) is one of the leading causes of bronchiolitis in children. We have shown that neonatal mice respond to primary RSV infection with T helper type 2 (Th2) biased immune responses, which are enhanced following reinfection. Dendritic cells (DCs) including myeloid DCs (mDCs) and plasmacytoid DCs (pDCs) play important roles in driving host responses to RSV infection. mDCs present antigens to help Th cells differentiate, and pDCs protect against viral infection through type I interferons (IFNs). Despite data demonstrating importance of mDCs and pDCs in protection against RSV, it has not been studied in an age appropriate model. Using a neonatal mouse model, we have shown that downregulation of IL-4 receptor alpha (IL-4R $\alpha$ ) on pulmonary myeloid dendritic cells (mDCs) via antisense oligonucleotides protected against RSV induced Th2 immunopathology. Thus, we examined the role of IL-4R $\alpha$ on mDCs in RSV infection. Here, we discovered that IL-4R $\alpha$ is developmentally regulated such that neonates have higher levels of IL-4R $\alpha$ on mDCs. To determine if this elevated expression of IL-4R $\alpha$ on mDCs was responsible for RSV pathogenesis in neonatal mice, we specifically deleted it from neonatal mDCs (or overexpressed it on adult mDCs) and studied RSV pathogenesis using our neonatal mouse model of RSV infection. Deletion of IL-4R $\alpha$ from mDCs in our neonatal RSV infection model resulted in reduced disease as evidenced by reduction in Th2 biased inflammation and mucus cell hyperplasia and production. This was accompanied by improved lung function and enhanced $\mathrm{mDC}$ maturation status after infection. Furthermore, overexpression of IL-4R $\alpha$ on adult mDCs was able to induce RSV disease similar to that observed in our neonatal model of RSV infection (i.e., Th2 biased responses including mucus hyperproduction). In vitro CD4+ T cell differentiation assays using mDCs from neonatal littermate control or IL-4R $\alpha-/-$ mice were also performed to determine the specificity of the in vivo response. Low levels of type I IFNs have been reported in the nasal aspirates of RSV-infected infants. Since pDCs are responsible for a significant proportion of type I IFN production, we characterized the role of type I IFNs and pDC responses in the immunopathogenesis during RSV reinfection in our neonatal mouse model. We found that neonatal pDCs, while recruited to the airways, are recruited in low numbers in the response to neonatal RSV infection. Further, those pDCs that are recruited produce insufficient quantities of type I IFNs. Supplying IFN- $\alpha$ or adult pDCs locally to the neonatal mouse prior to RSV infection in neonates abrogated RSV induced immunopathophysiologies and this protection remained even after reinfection. Specifically, it reduced Th2 responses and lung inflammation and improved lung function. This improvement was due to a decrease in viral load and IL-4R $\alpha$ expression on Th2 cells after IFN- $\alpha$ treatment. The severity of RSV pathogenesis in infants stems partly from immature immune responses. Our data demonstrate that developmentally regulated IL-4R $\alpha$ expression on $\mathrm{mDC}$ and inefficient type I IFN production from neonatal pDCs are critical for protection against RSV induced immunopathophysiologies. This study highlights critical differences between neonatal and adult DCs in RSV infection.
\end{abstract}

\section{Document Type}

Dissertation

\section{Degree Name}

Doctor of Philosophy (PhD)

\section{Program}

Biomedical Sciences 


\section{Research Advisor}

Stephania A. Cormier, Ph.D.

\section{Keywords}

Dendritic cells, Neonates, RSV, Th2

\section{Subject Categories}

Biological Phenomena, Cell Phenomena, and Immunity | Diseases | Medical Biochemistry | Medical Cell Biology | Medical Molecular Biology | Medical Sciences | Medicine and Health Sciences | Virus Diseases 


\title{
Role of Dendritic Cells in Pathology of Respiratory Syncytial Virus Infection in
} Neonates

\author{
A Dissertation \\ Presented for \\ The Graduate Studies Council \\ The University of Tennessee \\ Health Science Center
}

\author{
In Partial Fulfillment \\ Of the Requirements for the Degree \\ Doctor of Philosophy \\ From The University of Tennessee
}

By

Bishwas Shrestha

May 2017 
Chapter 2 Copyright (C) 2017 by Society for Leukocyte Biology Chapter 3 (C) 2014 by American Society for Microbiology

All other material (C) 2017 by Bishwas Shrestha All rights reserved. 


\section{DEDICATION}

Dedicated to Bishnu Shrestha, my uncle. 


\section{ACKNOWLEDGEMENTS}

I would like to express my sincere gratitude to Dr. Stephania Ann Cormier for being a terrific mentor. Her enthusiasm towards science has inspired me to be a research scientist. She has supported and guided me with her helpful advice and patience. I would also like to thank my committee members; Drs. Christopher Waters, Kui Li, John De Vincenzo and Elizabeth Fitzpatrick for their support and constructive criticism that have helped me improve my work. I want to thank Dr. Dahui You for her advice and help throughout this program. I thank current and former members of the Cormier Lab who had been such a great team spirit. I also want to acknowledge the UTHSC Department of Microbiology, Immunology, and Biochemistry, and IPBS committee.

Special thanks to my incredible family and friends of Memphis for their support. Without them, I would not be able to accomplish this challenging goal.

This study would have not been successful without funding support from NIAID grant (R01 AI090059) and NIEHS grants (R01 ES015050 and P42 ES013648). 


\begin{abstract}
Respiratory syncytial virus (RSV) is one of the leading causes of bronchiolitis in children. We have shown that neonatal mice respond to primary RSV infection with $\mathrm{T}$ helper type 2 (Th2) biased immune responses, which are enhanced following reinfection. Dendritic cells (DCs) including myeloid DCs (mDCs) and plasmacytoid DCs (pDCs) play important roles in driving host responses to RSV infection. mDCs present antigens to help Th cells differentiate, and pDCs protect against viral infection through type I interferons (IFNs). Despite data demonstrating importance of $\mathrm{mDCs}$ and $\mathrm{pDCs}$ in protection against RSV, it has not been studied in an age appropriate model.

Using a neonatal mouse model, we have shown that downregulation of IL-4 receptor alpha (IL-4R $\alpha$ ) on pulmonary myeloid dendritic cells ( $\mathrm{mDCs}$ ) via antisense oligonucleotides protected against RSV induced Th2 immunopathology. Thus, we examined the role of IL-4R $\alpha$ on mDCs in RSV infection. Here, we discovered that IL$4 \mathrm{R} \alpha$ is developmentally regulated such that neonates have higher levels of IL-4R $\alpha$ on $\mathrm{mDCs}$. To determine if this elevated expression of IL-4R $\alpha$ on mDCs was responsible for RSV pathogenesis in neonatal mice, we specifically deleted it from neonatal mDCs (or overexpressed it on adult $\mathrm{mDCs}$ ) and studied RSV pathogenesis using our neonatal mouse model of RSV infection. Deletion of IL-4R $\alpha$ from mDCs in our neonatal RSV infection model resulted in reduced disease as evidenced by reduction in Th2 biased inflammation and mucus cell hyperplasia and production. This was accompanied by improved lung function and enhanced $\mathrm{mDC}$ maturation status after infection. Furthermore, overexpression of IL-4R $\alpha$ on adult mDCs was able to induce RSV disease similar to that observed in our neonatal model of RSV infection (i.e., Th2 biased responses including mucus hyperproduction). In vitro CD4 $\mathrm{T}$ cell differentiation assays using $\mathrm{mDCs}$ from neonatal littermate control or IL-4R $\alpha-/-$ mice were also performed to determine the specificity of the in vivo response.
\end{abstract}

Low levels of type I IFNs have been reported in the nasal aspirates of RSVinfected infants. Since pDCs are responsible for a significant proportion of type I IFN production, we characterized the role of type I IFNs and $\mathrm{pDC}$ responses in the immunopathogenesis during RSV reinfection in our neonatal mouse model. We found that neonatal pDCs, while recruited to the airways, are recruited in low numbers in the response to neonatal RSV infection. Further, those pDCs that are recruited produce insufficient quantities of type I IFNs. Supplying IFN- $\alpha$ or adult pDCs locally to the neonatal mouse prior to RSV infection in neonates abrogated RSV induced immunopathophysiologies and this protection remained even after reinfection. Specifically, it reduced Th2 responses and lung inflammation and improved lung function. This improvement was due to a decrease in viral load and IL-4R $\alpha$ expression on Th2 cells after IFN- $\alpha$ treatment.

The severity of RSV pathogenesis in infants stems partly from immature immune responses. Our data demonstrate that developmentally regulated IL-4R $\alpha$ expression on $\mathrm{mDCs}$ and inefficient type I IFN production from neonatal pDCs are critical for 
protection against RSV induced immunopathophysiologies. This study highlights critical differences between neonatal and adult DCs in RSV infection. 


\section{TABLE OF CONTENTS}

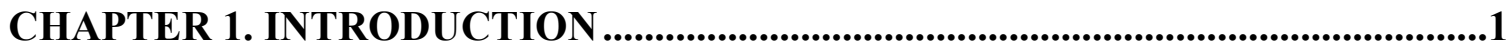

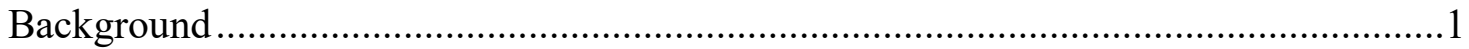

Respiratory Syncytial Virus ......................................................................... 1

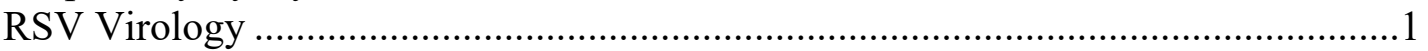

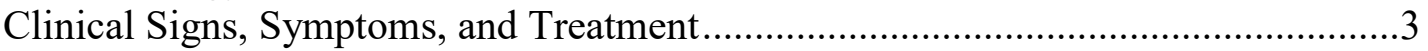

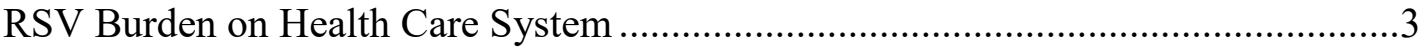

RSV Bronchiolitis Risk Factors .................................................................... 4

RSV and Infant Immunity ............................................................................. 4

Neonatal Mouse Model: An Age Relevant Model for RSV ....................................5

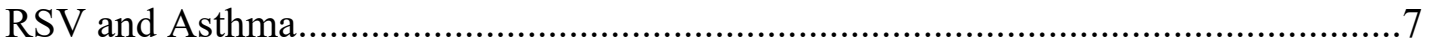

T Helper Type 2 Cells' Role in RSV Pathogenesis and Asthma ...............................

Dendritic Cells - Guide T Cell Differentiation in RSV Infection ..............................8

pDCs and Type I Interferons (IFN) ..............................................................

IL-4 and IL-13-Distinctive Roles in RSV Disease ............................................

Interleukin 4 Receptor Alpha (IL-4R $\alpha$ ) Is Correlated with RSV Pathogenesis..........9

Summary and Hypothesis .............................................................................

\section{CHAPTER 2. IL-4RA ON DENDRITIC CELLS IN NEONATES AND TH2 IMMUNOPATHOLOGY IN RESPIRATORY SYNCYTIAL VIRUS

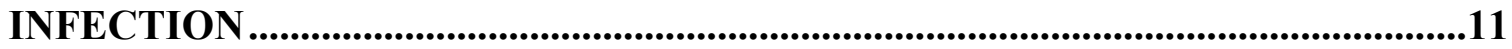

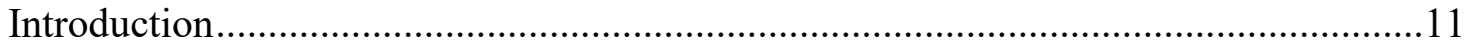

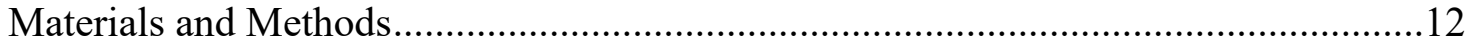

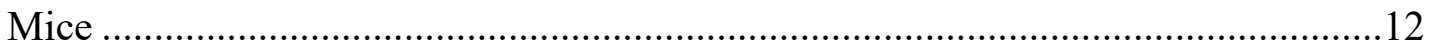

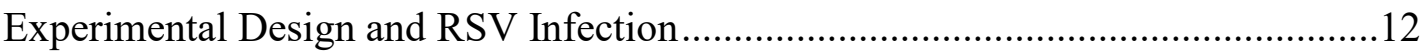

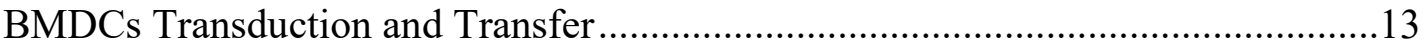

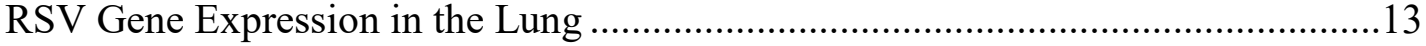

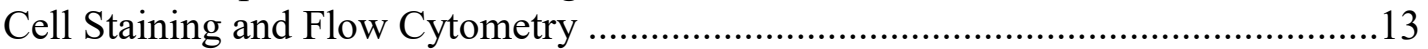

Bronchoalveolar Lavage Fluid (BALF) Cellularity............................................... 14

Pulmonary Function Test .............................................................................. 15

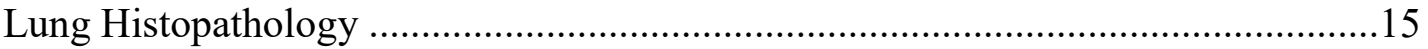

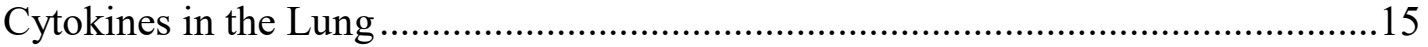

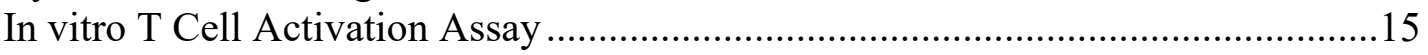

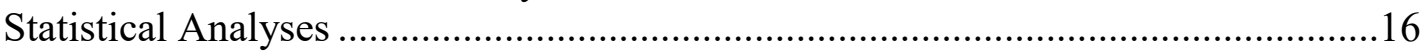

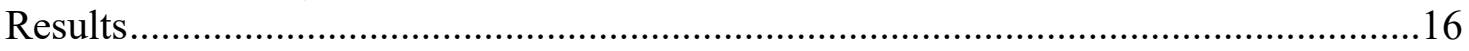

Expression of IL-4R $\alpha$ on Dendritic Cells Was Age Dependent ...............................16

Deletion of IL-4R $\alpha$ on CD11 ${ }^{+}$Cells Attenuated Th2-biased Immune Responses upon RSV Reinfection ............................................................................. 16

Deletion of IL-4R $\alpha$ on CD11 $\mathrm{c}^{+}$Cells Protected Mice from

Immunopathophysiology upon RSV Reinfection ...............................................19

Absence of IL-4R $\alpha$ on CD1 $1 b^{+}$mDCs Dampened Th2 Responses to RSV

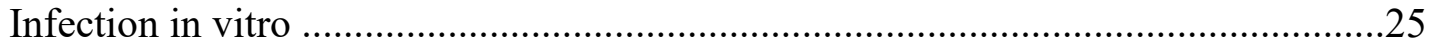

Loss of IL-4R $\alpha$ Expression on $\mathrm{CD}_{1} 1 \mathrm{~b}^{+} \mathrm{mDCs}$ Enhanced Their Maturation.............25 
Overexpression of IL-4R $\alpha$ on Adult mDCs Exacerbated Th2 Responses to RSV

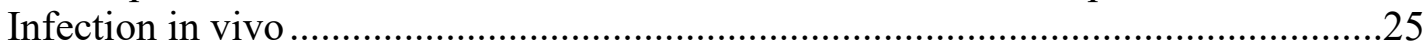

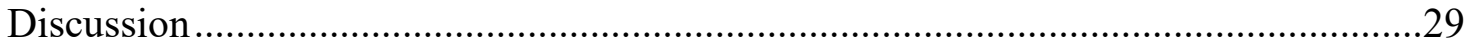

\section{CHAPTER 3. LIMITED TYPE I IFNS AND PLASMACYTOID DENDRITIC CELLS DURING NEONATAL RESPIRATORY SYNCYTIAL VIRUS INFECTION PERMIT IMMUNOPATHOGENESIS UPON REINFECTION........33}

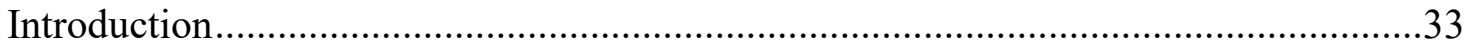

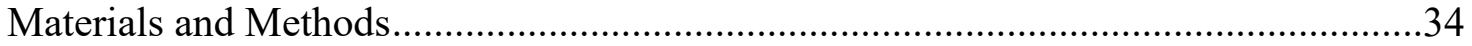

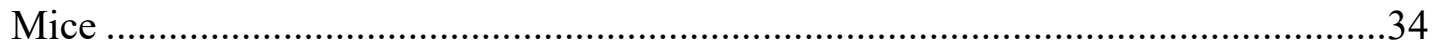

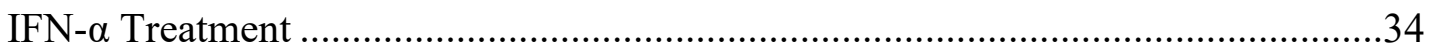

Purification of pDCs or CD1 $1 \mathrm{c}^{+}$Cells and Adoptive Transfer................................34

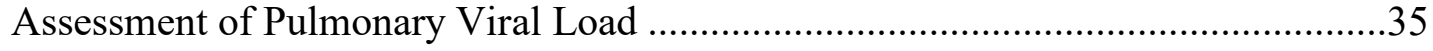

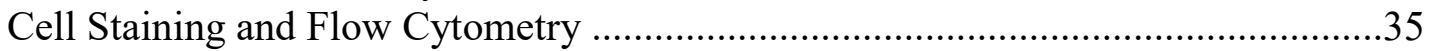

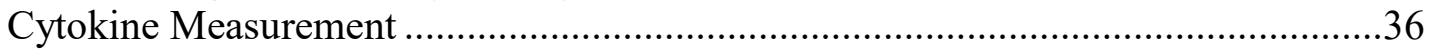

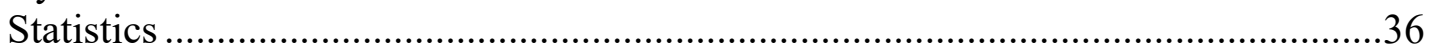

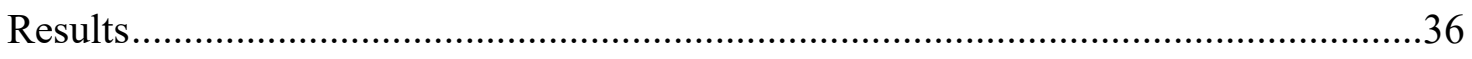

RSV Infection Induced Limited Type I IFNs and pDC Responses in Neonatal

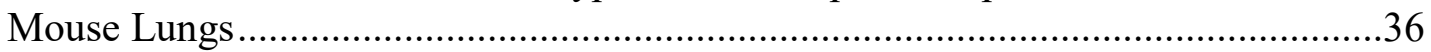

IFN- $\alpha$ Treatment Prior to Neonatal RSV Infection Mitigated Airway

Hyperreactivity and Lung Pathology during Reinfection .......................................37

IFN- $\alpha$ Treatment Prior to Neonatal RSV Infection Mitigated Th2-biased

Responses during Reinfection............................................................................4

Adoptive Transfer of Purified Adult pDCs Prior to Neonatal RSV Infection

Induced Pulmonary IFN- $\alpha$ Expression and Alleviated RSV Reinfection-

Associated Immunopathophysiology.....

IFN- $\alpha$ Treatment or Adoptive Transfer of pDCs Prior to Neonatal RSV Infection

Reduced Pulmonary Viral Load during Primary Infection ....................................45

IFN- $\alpha$ Treatment Prior to Neonatal RSV Infection Reduced IL-4R $\alpha$ Expression on T Helper Cells during Primary Infection ....................................................47

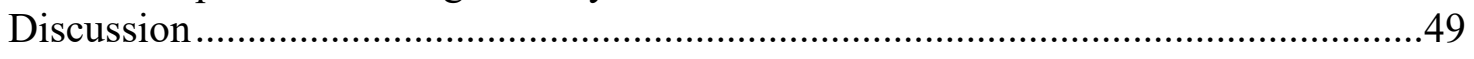

\section{CHAPTER 4. DISCUSSION, CONCLUSION, AND PERSPECTIVE ....................52}

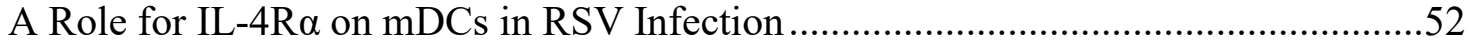

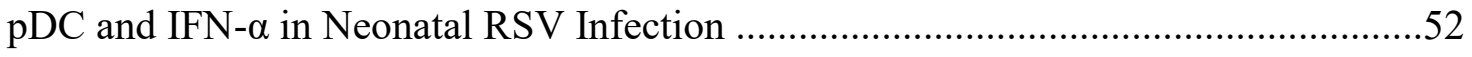

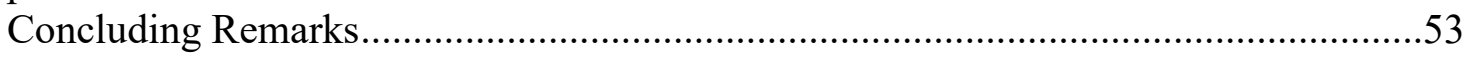

LIST OF REFERENCES ...................................................................................56

VITA 


\section{LIST OF FIGURES}

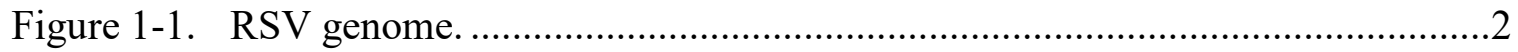

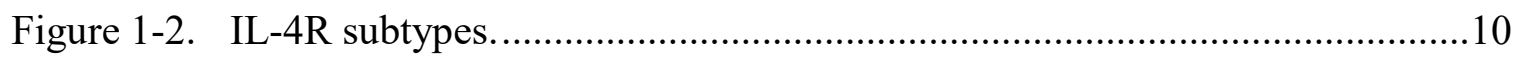

Figure 2-1. Gating strategy for pulmonary DCs.....................................................17

Figure 2-2. Expression of IL-4R $\alpha$ on dendritic cells was age dependent.......................18

Figure 2-3. IL-4R $\alpha$ expression on pulmonary $\mathrm{CD}_{11} 1 \mathrm{~b}^{+} \mathrm{mDCs}, \mathrm{CD}_{103^{+}} \mathrm{mDCs}$, and AMs was decreased in $\mathrm{CD} 11 \mathrm{c}^{+}$specific, IL-4R $\alpha$ deficient mice.................20

Figure 2-4. Deletion of IL-4R $\alpha$ on $\mathrm{CD} 11 \mathrm{c}^{+}$cells attenuated Th2-biased immune responses upon RSV reinfection.

Figure 2-5. The amount of mDCs, $\mathrm{CD} 11 \mathrm{~b}^{+} \mathrm{mDCs}$, and $\mathrm{CD}_{103^{+}} \mathrm{mDCs}$ did not change in $\mathrm{CD} 11 \mathrm{c}^{+}$specific, IL-4R $\alpha$ deficient mice.

Figure 2-6. Deletion of IL-4R $\alpha$ on $\mathrm{CD} 11 \mathrm{~b}^{+} \mathrm{mDCs}$ protected mice from immunopathophysiology upon RSV reinfection.

Figure 2-7. Absence of IL-4R $\alpha$ on $\mathrm{CD} 11 \mathrm{~b}^{+} \mathrm{mDCs}$ dampened $\mathrm{Th} 2$ responses to RSV infection in vitro.

Figure 2-8. Loss of IL-4R $\alpha$ on $\mathrm{CD}_{1} 1 \mathrm{~b}^{+} \mathrm{mDCs}$ enhances their maturation response to RSV.

Figure 2-9. GFP and IL-4R $\alpha$ expression on BMDCs was increased after transduction.

Figure 2-10. Overexpression of IL-4R $\alpha$ on adult $\mathrm{CD} 11 \mathrm{~b}^{+} \mathrm{mDCs}$ exacerbated Th2 responses to RSV infection in adult mice.

Figure 3-1. RSV infection induced limited type I IFNs in neonatal mouse lungs............38

Figure 3-2. RSV infection induced limited recruitment of pDCs to neonatal lungs. ......39

Figure 3-3. IFN- $\alpha$ treatment prior to neonatal RSV infection attenuated AHR, inflammation, and mucus hyperproduction during RSV reinfection.

Figure 3-4. IFN- $\alpha$ treatment prior to neonatal RSV infection mitigated the Th2biased responses during reinfection.

Figure 3-5. Adoptive transfer of adult pDCs prior to neonatal RSV infection induced pulmonary IFN- $\alpha$ expression and attenuated the Th2-biased immunopathologies during RSV reinfection. 
Figure 3-6. IFN- $\alpha$ treatment or adoptive transfer of pDCs decreased pulmonary viral

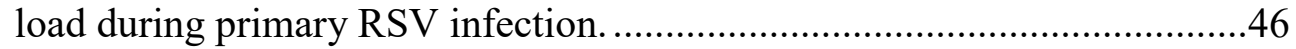

Figure 3-7. IFN- $\alpha$ treatment reduced Th responses to primary RSV infection in

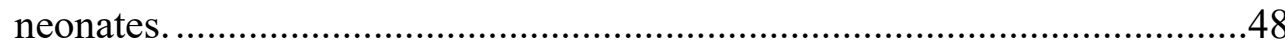

Figure 4-1. Schematic representation of immune response to RSV in neonates.............54 


\section{LIST OF ABBREVIATIONS}

$\begin{array}{ll}\text { AHR } & \text { Airway hyperreactivity } \\ \text { AM } & \text { Alveolar macrophages } \\ \text { AR } & \text { Adult mice infected with RSV } \\ \text { ASO } & \text { Antisense oligonucleotide } \\ \text { BAL } & \text { Bronchoalveolar lavage } \\ \text { BMDCs } & \text { Bone marrow derived dendritic cells } \\ \text { DCs } & \text { Dendritic cells } \\ \text { F protein } & \text { Fusion protein of RSV } \\ \text { FLT3L } & \text { Fms-like tyrosine kinase 3 ligand } \\ \text { G protein } & \text { Glyco protein of RSV } \\ \text { H\&E } & \text { Hematoxylin and eosin } \\ \text { IFN- } \alpha & \text { Interferon alpha } \\ \text { IL-4R } \alpha & \text { Interleukin 4 receptor alpha } \\ \text { IL-4R } \alpha^{-/-D C} & \text { Mice in which IL-4R } \alpha \text { in specifically deleted on dendritic cells } \\ \text { IL-4R } \alpha^{\text {lox/- DC }} & \text { Littermate control mice in which IL-4R } \alpha \text { is present on dendritic } \\ \text { LRT } & \text { Lower respiratory tract } \\ \text { mDCs } & \text { Myeloid dendritic cells } \\ \text { NKT } & \text { Natural killer cells } \\ \text { NR } & \text { Neonatal mice infected with RSV } \\ \text { PAS } & \text { Periodic acid-Schiff } \\ \text { pDCs } & \text { Plasmacytoid dendritic cells } \\ \text { RR } & \text { RSV infected mice during neonates and reinfected 4 weeks later } \\ \text { RSV } & \text { Respiratory syncytial virus } \\ \text { SFM } & \text { Serum free media } \\ \text { Sham } & \text { Mice treated with media } \\ \text { SNP } & \text { Single nucleotide polymorphism } \\ \text { URT } & \text { Upper respiratory tract } \\ \text { pLV-eGFP } & \text { Lentiviral vector with eGFP } \\ \text { pLV-IL-4R } \alpha-e G F P ~ & \text { Lentiviral vector with IL-4R } \alpha \text { and eGFP } \\ & \end{array}$




\section{CHAPTER 1. INTRODUCTION}

\section{Background}

\section{Respiratory Syncytial Virus}

In 1956, a virus infection in chimpanzees at the Walter Reed Army Institute of Research induced cold like symptoms and was named coryza agent (1). In 1957, Chanock found a similar virus in two human infants with severe respiratory illness, and a few years later, many children with respiratory symptoms were diagnosed with the same virus (2). This coryza agent induced the formation of multinucleated giant cell syncytia in tissue cultures, so it was named respiratory syncytial virus (RSV). RSV is one of the leading causes of respiratory infection in infants. It is ubiquitous and infects almost every child by age 2 , with recurrence and reinfection being quite common (3). Generally, RSV causes common cold like symptoms and mild illness. However, in some infants RSV infection causes severe bronchiolitis requiring hospitalization. Mortality due to RSV infection is also considerably high accounting for as much as 66,000 -199,000 deaths with $99 \%$ occurring in developing countries (4). Although RSV was discovered over a half a century ago (1), we still have not been able to develop a vaccine to protect against RSV infection.

\section{RSV Virology}

RSV is a negative-sense, single-stranded RNA virus; it is enveloped, nonsegmented and belongs to the family paramyxoviridae and subfamily of pneumovirinae. The RSV genome is about $15.2 \mathrm{~kb}$ long and consists of 10 genes (Figure -1-1). Genes named N, P, M, L, and M2 help in the assembly of the virus. The two genes, NS1 and NS2, play a role in evading immune responses by interfering with the production of type I interferons (IFNs) (5). G and F surface proteins are implicated in viral entry by allowing attachment and fusion respectively to the cell's plasma membrane. These surface proteins are of interest because neutralizing antibodies can be raised against them. G protein is heavily glycosylated and has variable regions. Based on the variability of $\mathrm{G}$ protein and reaction against monoclonal antibodies, RSV has been divided into two types RSV A and RSV B (6). RSV A is further subdivided into 12 genotypes and RSV B into 20 genotypes (7). $\mathrm{G}$ and $\mathrm{F}$ protein are known to modulate immune responses. A CX3C motif in the $\mathrm{G}$ protein binds to CX3CR1 receptor on epithelial cells and competes with the CX3CL1 chemokine for binding. Since CX3CL1 chemokines are chemoattractants for inflammatory immune cells, G protein competition with CX3CL1 affects immune cell trafficking (8). Unlike $\mathrm{G}$ protein, $\mathrm{F}$ is highly conserved, so some drugs are targeted against this protein (9). 


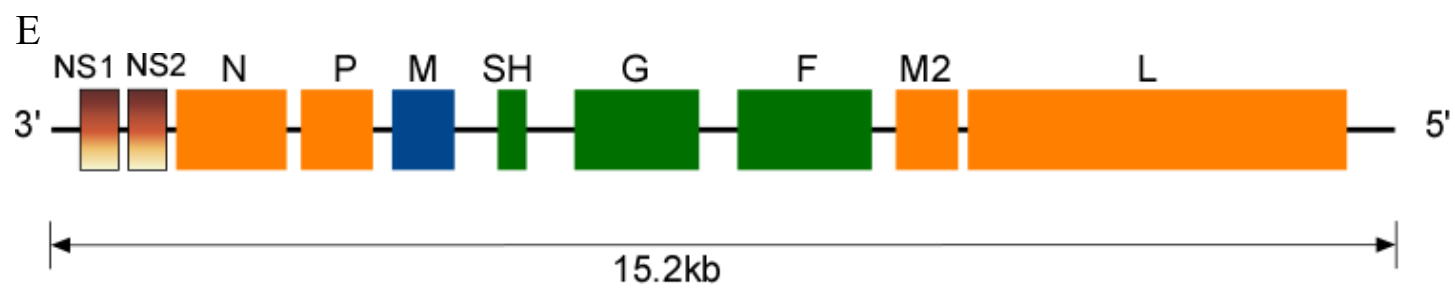

NS-Non-Structural proteins

N-Nucleocapsid, P-Phosphoprotein, M2-M2 Matrix protein, L-Large polymerase

SH-Small hydrophobic protein, G-Glycoprotein, F-Fusion protein

M-Matrix protein

Figure 1-1. RSV genome.

The human RSV genome is approximately $15.2 \mathrm{~kb}$ in length and consists of 10 mRNAs and 11 proteins. NS1 and NS2 are nonstructural genes that encode NS1 and NS2 proteins. N, P, M2, L encode structural proteins. SH, G, and F encode envelope proteins for attachment and fusion. $M$ encodes for matrix protein $(10,11)$. 


\section{Clinical Signs, Symptoms, and Treatment}

RSV is highly contagious and generally infects the upper respiratory tract (URT) and causes cold like symptoms such as coughing, sneezing, wheezing, fever, and otitis media (4). Unfortunately, it sometimes infects the lower respiratory tract (LRT) and causes bronchiolitis and pneumonia (4). Usually, the symptoms last for about 4-8 days; and if hospitalized, the length of hospital stay ranges from 3-7 days (10). However, preterm babies and immunocompromised patients, who are at the highest risk of developing severe bronchiolitis during RSV infection, can be hospitalized for several months (11).

Treatments available for infants are supportive care such as hydration and saline nasal drops to clear the nasal passage for breathing. Oxygen and mechanical ventilation are given to patients with higher risks of respiratory failure, which are often those with congenital birth and heart defects $(3,12)$. Bronchodilators, corticosteroids, and ribavirin (antiviral) are expensive and do not provide much benefit in these patients (13). Palivizumab, a monoclonal antibody against the F protein of RSV, is used as a prophylactic and has been shown to neutralize the virus and abrogate pathogenesis (14, 15). However, it is expensive (about $\$ 1000$ for $100 \mathrm{mg}$ ) and only given to children at high risk like preterm babies and children with congenital heart or lung disease. Several antivirals and small molecules such as fusion inhibitors and polymerase inhibitors have been developed but are still in clinical trials $(16,17)$. Due to the failure of the formalin inactivated RSV vaccine trial of the 1960s, the progress of vaccine development has been slow. No approved vaccines are available for RSV.

\section{RSV Burden on Health Care System}

Every year, RSV infection results in hospitalization for over 3 million children and almost 66,000 deaths worldwide $(3,4)$. In the US alone, 85,000 to 144,000 children are hospitalized due to RSV every year (3). Although the mortality rate is higher in developing countries, the burden of health care in developed countries is also significantly high. An estimated $\$ 2.6$ billion dollars is spent on medical treatment for RSV in the US exerting an enormous burden on the pediatric heath care system. (18). RSV accounted for $15 \%$ of pediatric office visits and $18 \%$ of emergency department visits out of 5067 children less than 5 years of age in the 2004 winter season according to a study conducted in Nashville, Rochester, and Cincinnati (3). It remains the number one etiological agent for hospitalization of infants compared to any other respiratory pathogens including influenza (19).

RSV is not only a risk for children but also a problem for adults. $10-20 \%$ of pneumonia and respiratory problems in nursing homes stems from RSV infection (20). Cough, fever, wheezing, and nasal congestion are some common symptoms in elderly patients. About 10,000 adults die every year due to RSV infection in the US, and 100,000 admitted to the hospital for respiratory symptoms (20). RSV can also be life threatening for patients who are immune compromised such as HIV patients, transplant recipients, 
cancer patients receiving chemotherapy, and patients with heart or lung defects such as COPD patients (21).

\section{RSV Bronchiolitis Risk Factors}

Some RSV infected children experience mild illness, while others develop severe bronchiolitis. Several factors confer risk for developing bronchiolitis including age, prematurity, low birth weight, sex, economic status, the number of siblings, genetic factors, etc. (3). Infants less than 6 months of age are more prone to developing bronchiolitis upon RSV infection $(22,23)$. Single nucleotide polymorphisms (SNPs) in various genes such as IL-8, IL-4R $\alpha$, IL-4, IL-13, TLR-4, IFNA5, surfactant, vitamin D receptor have also been determined as risk factors for severe RSV disease $(24,25)$. Males are more susceptible to RSV LRTI and have a higher mortality rate due to RSV infection than females (26). Maternal factors such as smoking, unhealthy diet, low vitamin D levels, and breast-feeding have all been associated with increased risk to develop RSV bronchiolitis $(25,27,28)$.

\section{RSV and Infant Immunity}

Susceptibility of infants and neonates to RSV infection can be attributed to their immature lung development as well as immune responses which are different from that of adults. Both quantitative and qualitative differences have been discovered in the immune response of infants compared to adults (29). Monocyte progenitor cells, granulocytes and natural killer T cells (NKT) are significantly lower in number in cord blood from human newborns compared to those in adult peripheral blood (29). Phenotypically, human leukocyte antigen (MHCII) and CD40 expression are lower on fetal monocytes and dendritic cells compared to adult when stimulated with LPS (30). TLR signaling is also compromised in the infant with reduced overall TLR expression (31). However, some inflammatory cytokines such as IL-6, IL-10, IL-23, and phosphate molecules such as cAMP are produced in copious amounts in human cord blood mononuclear cells (32-34) suggesting unruly control of inflammation such that the infant immune system is considered to be distinct from that of an adult.

Besides innate immune responses, the factors that affect adaptive immune responses such as soluble blood plasma concentrations of adenosine and complement components are also lower in neonatal cord blood compared to adults (29). Further, mounting evidence suggests that the infant immune system is T helper type 2 cells (Th2) biased compared to that of adults $(35,36)$. Naïve $\mathrm{CD}^{+} \mathrm{T}$ cells of neonates and infants from cord blood and PBMCs preferentially develop into IL-4 producing CD ${ }^{+} \mathrm{Th} 2$ cells compared to adult naïve $\mathrm{CD} 4^{+} \mathrm{T}$ cells (37). Similar findings of $\mathrm{Th} 2$ bias in neonatal animals have been reported as well $(38,39)$. The reasons for this $\mathrm{Th} 2 \mathrm{biased}$ responses in human infants are due to various factors such as low production of T helper 1(Th1) promoting cytokine, IL-12 by dendritic cells (40) and increased levels of IL-10 (34). 
Hypomethylation of the Th2 locus in murine neonatal $\mathrm{T}$ cells is another factor that makes Th2 genes readily available to transcription factors (41).

Furthermore, RSV infection in infants has been shown to further exacerbate this Th2 biased response $(42,43)$. IL-4 cytokine occurs at higher concentrations than interferon $\gamma$ (IFN $\gamma$, a Th1 cytokine) in bronchoalveolar lavage fluid (BAL) of infants diagnosed with RSV (42). Moreover, a study comparing Th2 cytokines in serum of RSV infected versus influenza infected infants showed higher amounts of Th2 cytokines (IL-4 and IL-5) in RSV patients (44), suggesting the Th2 biased response is virus specific. In fact, researchers studying the immune response after RSV bronchiolitis followed a cohort during the first 6 years of life and found that Th2 cytokines in patients with RSV bronchiolitis increased over time, and Th1 cytokines decreased after RSV infection (45). Further, autopsy results from children that died from severe RSV infection after receiving a formalin-inactivated RSV vaccine and being infected with RSV showed increased eosinophils (indicative of a Th2 response) (46). Thus, this Th2 bias is thought to contribute to RSV pathogenesis.

\section{Neonatal Mouse Model: An Age Relevant Model for RSV}

Several models for RSV infection have been proposed and studied. RSV infection has been studied in primates, sheep, rats and mice. Nonhuman primates like chimpanzees, rhesus monkey, bonnet monkey, and baboon are better models to study human RSV but cost restrictive, and the use of chimpanzees are restricted by NIH. Cotton rats are more permissive to RSV infection compared to ferrets (47) and have also been used in vaccine and therapeutic studies for RSV. Cotton rats also show pulmonary histopathology similar to humans including peribronchiolitis, perivasculitis, and interstitial pneumonitis (48). However, unlike humans, the cotton rat model does not generate pulmonary eosinophilia (a characteristic Th2 effector cell). Mouse models are used to study RSV due to their short gestation period and availability of reagents. BALB/c mice have been used by a number of laboratories to understand RSV pathogenesis, due to the availability of transgenic and knockout lines to address mechanistic questions and most importantly because they are susceptible to RSV infection and are predisposed to mount Th2 responses.

Since age at initial infection inversely correlates with RSV severity $(49,50)$, the use of an adult mouse model seemed unjustifiable. Our group $(51,52)$ and others have established a neonatal mouse model of RSV infection (53-56). Neonatal mice are defined as 5-7 days of age and are immunologically similar to human infants of 0 to 6 months ofof age as reviewed in (57). In this model, neonatal mice are infected as neonates with RSV. This single infection induced lung dysfunction, mucus hyper-production, and airway remodeling compared to the mice infected as weanlings or adults (53). Further, reinfection of these mice as adults enhances RSV immunopathophysiology (e.g., exaggerated pulmonary Th2 cells/cytokines, eosinophilia, and airway hyperreactivity) (Table 1-1) (52, 53). 
Table 1-1. A comparison of neonatal and adult mouse RSV infection models with severe RSV disease in human infants.

\begin{tabular}{lccc}
\hline Characteristics & $\begin{array}{l}\text { Severe Human RSV } \\
\text { Infection }(<1 \text { year old })\end{array}$ & $\begin{array}{c}\text { Neonatal Mouse Model } \\
(<7 \text { days old })\end{array}$ & $\begin{array}{c}\text { Adult Mice } \\
\text { Wheeze }\end{array}$ \\
$\begin{array}{l}\text { Mucus } \\
\text { Pulmonary }\end{array}$ & $\checkmark$ & $\checkmark$ & $\checkmark *$ \\
eosinophilia & $\checkmark$ & $\checkmark$ & $\checkmark$ \\
Th2-biased immune & & $\checkmark$ & \\
$\begin{array}{l}\text { response } \\
\text { Epithelial sloughing }\end{array}$ & $\checkmark$ & & \\
$\begin{array}{l}\text { Epithelial } \\
\text { hypertrophy }\end{array}$ & $\checkmark$ & $\checkmark$ & \\
$\begin{array}{l}\text { Hyperplasia of } \\
\text { goblet cells }\end{array}$ & $\checkmark$ & $\checkmark$ & \\
$\begin{array}{l}\text { Increased } \\
\text { extracellular matrix } \\
\text { deposition }\end{array}$ & $\checkmark$ & $\checkmark$ & \\
$\begin{array}{l}\text { Long-term Airway } \\
\text { hyperresponsiveness }\end{array}$ & $\checkmark$ & $\checkmark$ & \\
\hline
\end{tabular}

Notes: $\checkmark *$ : means RSV strain dependent 
Different clinically relevant strains of RSV other than A2 have been used in adult mice to elicit disease similar to that observed in severe RSV-infected infants $(58,59)$. However, these are still adult mice with fully matured immune and pulmonary systems and it is not clear how relevant this data is to infant airway disease resulting from RSV infection. To study the appropriate immunopathologies resulting from priming of neonatal immune responses by RSV, our group used a chimeric virus (rA2-19F) in a neonatal mouse model (60). This model elicited more severe disease including interstitial pneumonitis and alveolitis as observed in some human infants.

\section{RSV and Asthma}

Numerous studies suggest that there is a link between RSV infection and asthma that is not due to atopy or parental asthma $(49,50,61,62)$. While all studies note a longterm association between RSV bronchiolitis and asthma, the duration of lung dysfunction following RSV infection is disputed. For example, while the Tucson study noted an association between RSV infection and wheeze, it also noted that this association was lost when the children reached 13 years of age (61). Other studies including those of Sigurs et al (50) and Piippo-Savolainen et al (62) demonstrated associations between RSV and asthma that lasted until adulthood (18-22 years of age). It is interesting to note the differences between these studies, in the Tucson study children were 1-3 years old (median age $>$ than 1 year old) years old and had mild disease. Whereas, in the later studies, children were under 1 year of age (median age $<6$ months) and were hospitalized (i.e. had severe disease). The Tennessee Asthma Bronchiolitis Study (TABS) demonstrates that age during RSV season is an important risk factor for later wheeze (49). In total, these studies suggest that age (infants less than a year old) and severity (hospitalization) are independent predictors of development of asthma following RSV infection.

\section{T Helper Type 2 Cells' Role in RSV Pathogenesis and Asthma}

Th2 cells are needed for immunity to extracellular infections such as helminths and parasites. RSV infection also activates Th2 cells leading to the production of IL-4, IL-5, and IL-13 cytokines. These cytokines promote IgE and IgG1 antibody production by B cells against RSV (63). Granulocytes (i.e. eosinophils, basophils, and mast cells) have receptors for IgE, and they are attracted to the inflamed tissues by chemokines produced from the RSV infected cells (64). Cross-linking of the surface bound antibody $\operatorname{IgE}$ and $\operatorname{IgG} 1$ to its antigen causes these cells to degranulate and release inflammatory mediators such as leukotrienes, prostaglandins, and histamines (64). These inflammatory factors cause vascular permeability, swelling, and smooth muscle cell contraction. Chronic inflammation also leads to remodeling like wall thickening, sub-epithelial fibrosis, and smooth muscle hyperplasia $(65,66)$. Thus, RSV infection in infants promotes Th2 cells and Th2 cytokine IL-13 which causes airway remodeling, mucus hyperproduction and airway hyper-reactivity similar to allergic asthma. 


\section{Dendritic Cells - Guide T Cell Differentiation in RSV Infection}

Dendritic cells constantly patrol the mucosal surfaces and act to initiate the adaptive arm of the immune response in the course of RSV infection. As the viral burden increases, different types of dendritic cells are recruited into the lungs at the time of infection, conventional dendritic cells or myeloid dendritic cells (mDCs) and plasmacytoid dendritic cells ( $\mathrm{pDCs}$ ). mDCs present antigen to T cells, and are divided into two subtypes which interact with different $\mathrm{T}$ cells. $\mathrm{CD} 11 \mathrm{~b}^{+} \mathrm{mDC}$ mainly present antigens to $\mathrm{CD}^{+} \mathrm{T}$ cells and thus guide Th cell differentiation (67), while $\mathrm{CD} 103^{+} \mathrm{mDCs}$ mainly cross-present antigens to $\mathrm{CD}^{+} \mathrm{T}$ cells (68). Besides interaction with $\mathrm{T}$ cells, DCs also produces other pro-inflammatory cytokines such as IL-1 $\beta$, IL-6, IL-12, IFN- $\gamma$, and TNF- $\alpha,(69)$ and chemokines such as CCL2, CCL3, CCL4, CXCL8 (70) to orchestrate the immune response. The type of immune response elicited depends on the interaction between the mDCs and the naïve T cells, and the cytokine milieu present at the time. Mouse studies have shown that neonatal mDCs produce low levels of IL-12 and suboptimally stimulate Th cells and cytotoxic Tc cells compared to adult mDCs (71). So we believe that low IL-12 levels and sub-optimal stimulation of Th cells lead to their differentiation into Th2 cells resulting in a Th2 dominant response in the lungs after RSV infection $(72,73)$.

\section{pDCs and Type I Interferons (IFN)}

pDCs are a small subset of DCs which initiate an antiviral response by producing type I IFNs (74). Several studies have shown a protective role for $\mathrm{pDCs}$ and type I IFNs in RSV infection in the adult mice (75). However, the role of pDCs and type I IFNs in the neonates are unclear. Despite the presence of pDCs in nasal washes from children infected with RSV, there are low levels of type I IFNs suggesting a limited response from neonatal pDCs (76). Further, type I IFNs have been shown to promote Th1 differentiation, so we hypothesize that low levels of type I IFNs in infants and neonates during RSV infection pushes T helper cell away towards Th2 response (77).

\section{IL-4 and IL-13-Distinctive Roles in RSV Disease}

Polymorphisms in IL-4 and IL-13 have been linked to severe RSV infection [41]. However, these two Th2 cytokines have distinctive roles in Th2 mediated disease. IL-4 is mostly responsible for Th cell differentiation and basophil activation, while IL-13 is required for mucus hyperproduction and airway hyperreactivity. IL-13 is thought to be a primary cytokine that induces lung dysfunction after RSV infection. Patients with severe RSV disease during infancy produced higher levels of IL-13 when their sera were tested with RSV F and G antigen later at 5 years of age (73). Further antibodies targeting IL-13 post RSV infection decreased airway hyperreactivity (AHR) and mucus hyperproduction after RSV infection in mice (78). 


\section{Interleukin 4 Receptor Alpha (IL-4Ra) Is Correlated with RSV Pathogenesis}

Both IL-4 and IL-13 use a common receptor subunit called IL-4R $\alpha$. Polymorphisms in IL-4R $\alpha$ in humans have been associated with RSV hospitalizations and disease severity (79). The interleukin 4 receptor (IL-4R) is a heteromeric receptor found on a variety of immune cells such as dendritic cells, T cells, and B cells. There are two types of IL-4R. Type I consist of the IL-4R $\alpha$ subunit and the common gamma chain, and primarily bind IL-4. The type II receptor consists of the IL-4R $\alpha$ subunit and the IL$13 R \alpha 1$ and binds both IL-4 and IL-13. Signaling for both of these receptors occurs through JAK-STAT pathways (Figure 1-2). STAT 6 drives the transcription of GATA 3, which promotes Th2 differentiation from the type I IL-4R (80). Downregulation of IL$4 \mathrm{R} \alpha$ using antisense oligonucleotides (ASO) during RSV infection in neonatal mice has been shown to mitigate the Th2 biased response and prevent pulmonary pathophysiology (51). A prominent decrease was seen in levels of IL-4R $\alpha$ on mDCs with the use of ASO in mice prior to RSV infection. Thus, we hypothesize that IL-4R $\alpha$ on mDCs can play a significant role in inducing Th2 biased responses in RSV infection of neonates.

\section{Summary and Hypothesis}

$\mathrm{RSV}$ is a respiratory pathogen that infects infants worldwide and is capable of eliciting significant airway disease, which can result in long-term lung dysfunction in some individuals, and even mortality. RSV severity and the predisposition to develop asthma correlates with the initial age of RSV infection. Thus, we have been investigating the differences in infant and adult immune responses to RSV infection using neonatal (to mimic human infant) and adult mice. Since DCs guide Th2 differentiation which has been implicated in RSV pathogenesis, this dissertation sought to study the role of neonatal $\mathrm{mDCs}$ and $\mathrm{pDCs}$ in $\mathrm{Th} 2$ differentiation.

- We previously observed that downregulation of IL-4R $\alpha$, which binds Th2 cytokines IL-4 and IL-13, abrogates RSV induced Th2 pathogenesis. This was associated with downregulation of IL-4R $\alpha$ on pulmonary mDCs. Thus, we hypothesized that IL-4R $\alpha$ on mDCs plays a role in the development of the Th2 biased response to RSV. (Chapter 2)

- Further, several studies have suggested a role for pDCs and type I IFNs in protection from severe RSV disease. We hypothesized that neonatal pDCs elicit a limited type I IFN response allowing for Th2 immunopathophysiology in RSV infection. (Chapter 3) 


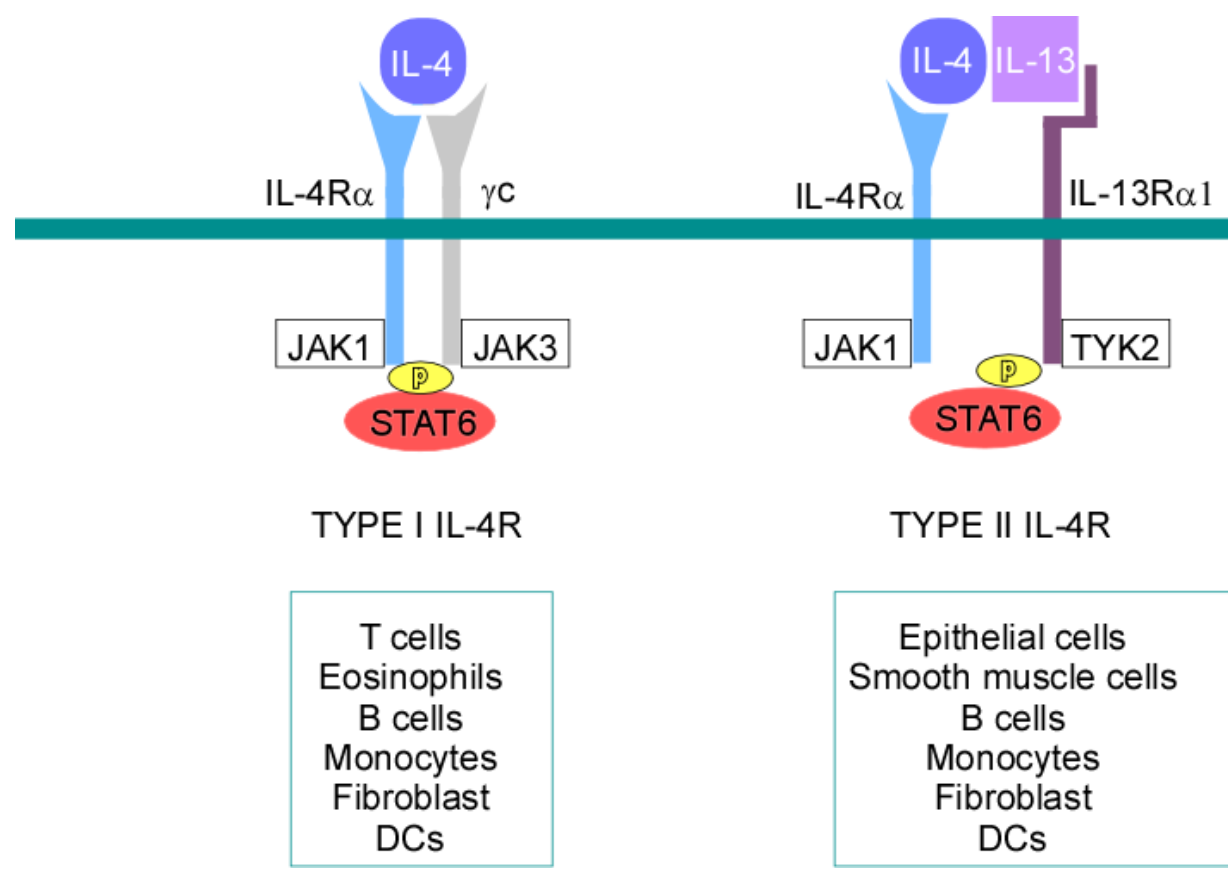

Figure 1-2. IL-4R subtypes.

The type I IL-4R consists of IL-4R $\alpha$ subunit and common gamma chain $(\gamma \mathrm{c})$ and binds IL4. The type II IL-4R consists of IL-4R $\alpha$ subunit and IL-13R $\alpha 1$ and binds both IL-4 and IL-13. These receptors act through the JAK-STAT pathway to activate STAT 6. Type I IL-4R is present on T cells, eosinophils, B cells, monocytes, fibroblast, and DCs. Type II IL-4R is present on smooth muscle cells, B cells, monocytes, fibroblast, and DCs. (83). 


\section{CHAPTER 2. IL-4R $\alpha$ ON DENDRITIC CELLS IN NEONATES AND TH2 IMMUNOPATHOLOGY IN RESPIRATORY SYNCYTIAL VIRUS INFECTION*}

\section{Introduction}

Respiratory syncytial virus (RSV) causes acute lower respiratory tract infections in infants, and it is the leading cause of bronchiolitis in children under one year of age (3, 81). RSV infection severe enough to require hospitalization during infancy is associated with increased risk for wheezing and development of asthma $(50,82)$. Currently, no effective vaccines or therapeutics for RSV exist. The development of such products is partially hindered by our lack of the knowledge of the infant immune system and its response to RSV infection.

RSV infection in infants induces a Th2-biased immune response, which is partly responsible for RSV pathogenesis $(43,83)$. A study comparing cytokine levels in the serum of RSV vs. influenza infected infants found higher concentrations of Th2 cytokines (IL-4 and IL-5) in RSV infected children (44), suggesting that the Th2-biased response is not simply an age-specific response but also a virus-specific response. Animal studies have reported similar findings $(38,52)$. Age at initial RSV infection is important in determining the Th2 bias (53); infection of neonatal mice and reinfection upon adulthood induces a Th2-biased immune response $(51,53,54)$. Further, polymorphisms in IL-4 receptor alpha (IL-4R $\alpha$ ) have been associated with RSV disease severity (79). We have previously shown that downregulation of IL-4R $\alpha$ with antisense oligonucleotide (ASO) during primary RSV infection in neonatal mice mitigated the Th2-biased immunopathophysiologies upon reinfection (51) which raises the intriguing possibility that IL-4R $\alpha$ plays a role in the immunopathogenesis of neonatal RSV infection.

Dendritic cells are antigen presenting cells that initiate and dictate the ensuing adaptive immune response following exposure to a pathogen. Dendritic cells are functionally divided into two main classes, myeloid dendritic cells $(\mathrm{mDCs})$ and plasmacytoid dendritic cells ( $\mathrm{pDCs}$ ). mDCs present antigens to T cells and help T cell differentiation, (84) whereas pDCs produce type I IFNs to combat viral infection (74). mDCs are further classified into $\mathrm{CD} 11 \mathrm{~b}^{+} \mathrm{mDCs}$ that mainly present antigens to $\mathrm{CD} 4^{+} \mathrm{T}$ cells $(67,68)$ and $\mathrm{CD} 103^{+} \mathrm{mDCs}$ that mainly cross-present antigens to $\mathrm{CD} 8^{+} \mathrm{T}$ cells $(68)$. Several functional and phenotypical differences have been shown between neonatal and adult DCs $(29,71,85)$. Additionally, RSV infection induces significantly less recruitment of pDCs and thus type I IFNs in the lung of neonatal vs. adult mice, (86) and pDCs from cord blood express lower levels of type I IFNs compared to pDCs from adult peripheral blood in response to RSV stimulation ex vivo (87).

*Adapted with permission. Shrestha B, You D, Saravia J, Siefker DT, Jaligama S, Lee GI, Sallam A, Harding JN, Cormier SA. IL -4R $\alpha$ on dendritic cells in neonates and Th2 immunopathology in respiratory syncytial virus infection. JLB. 2017. In Press. 
Neonatal mDCs express lower levels of costimulatory molecules (CD80 and CD86) and produce less IL-12 (a Th1 cytokine) in response to LPS compared to their adult counterparts $(29,71)$.

In the present study, we demonstrated an age-dependent expression of IL-4R $\alpha$ on pulmonary DCs. Neonatal CD $11 \mathrm{~b}^{+} \mathrm{mDCs}\left(\mathrm{CD} 11 \mathrm{c}^{+} \mathrm{MHCII}^{+} \mathrm{CD} 11 \mathrm{~b}^{+}\right)$and $\mathrm{pDCs}\left(\mathrm{CD} 11 \mathrm{c}^{+}\right.$ PDCA $-1^{+}$) expressed higher levels of IL-4R $\alpha$ compared to their adult counterparts, whereas neonatal $\mathrm{CD} 103^{+} \mathrm{mDCs}\left(\mathrm{CD} 11 \mathrm{c}^{+} \mathrm{MHCII}^{+} \mathrm{CD} 103^{+}\right)$expressed less IL-4R $\alpha$ than in adults. Since the age at initial infection is important in determining the Th2-biased immune response to RSV infection $(52,54,88)$ and $\mathrm{CD}_{11} \mathrm{~b}^{+}$mDCs are mainly responsible for antigen presentation and activation of $\mathrm{CD}^{+} \mathrm{T}$ cells, $(67,68)$ we hypothesized that the elevated expression of IL-4R $\alpha$ on neonatal $\mathrm{mDCs}$ is responsible for the Th2-biased immunopathogenesis of neonatal RSV infection. To test this hypothesis, we infected mice deficient in IL-4R $\alpha$ CD $11 b^{+}$mDCs (89) and evaluated the Th2-biased immune response to RSV in vitro and in vivo. Furthermore, we adoptively transferred $\mathrm{mDCs}$ that overexpressed IL-4R $\alpha$ into adult mice to confirm the importance of IL-4R $\alpha$ in the induction of Th2-biased immune responses to RSV. Our data demonstrate that high levels of IL-4R $\alpha$, as occurs in infancy, inhibits the maturation of CD11 $\mathrm{b}^{+} \mathrm{mDCs}$; and, for the first time, establish a critical role for IL-4R $\alpha$ on $\mathrm{CD}_{11} \mathrm{~b}^{+} \mathrm{mDCs}$ in initiating the Th2biased immunopathogenesis of neonatal RSV infection.

\section{Materials and Methods}

\section{Mice}

BALB/c mice were purchased from Harlan laboratories and housed in a specificpathogen-free animal facility at the University of Tennessee Health Science Center (UTHSC), Memphis, Tennessee, USA. CD11c-specific IL-4R $\alpha^{-/-}$mice (IL-4R $\alpha^{-/-D C}$ ) or their littermates (IL-4R $\left.\alpha^{-/ l o x ~ D C}\right)$ were generated by crossing IL-4R $\alpha^{\text {lox/lox }}$ mice with CD11c-cre IL-4R $\alpha^{-/-}$mice (gifts from Frank Brombacher, University of Cape Town, South Africa and generously donated by Debroski Herbert, University of California, San Francisco) (89). All mice were on BALB/c background. Breeders were time mated, and age-matched pups were used for all experiments. Neonatal mice were not identified for sex and both male and female were used for experiments. All animal experiments were performed according to Guidelines of Care and Use of Laboratory Animals and approved by UTHSC Animal Care and Use Committee.

\section{Experimental Design and RSV Infection}

Neonatal ( 5 days old) or adult mice (6 weeks old) were anesthetized using isoflurane and infected intranasally with human RSV strain A-2 (Advanced Biotechnologies; Columbia, MD, USA) $\left(2 \times 10^{5}\right.$ TCID $_{50}$ per gram body weight $)$ in $10 \mu 1$ (neonates) or $50 \mu 1$ (adults) of serum-free media (SFM; HyClone; Logan, UT, USA) or 
SFM alone (Sham). A subset of the cohort was allowed to mature and was reinfected at 4 weeks post primary infection. At 6 days post-reinfection, various endpoints were measured including lung function and histopathology, BALF cytokines or cellularity, and $\mathrm{T}$ cell profile.

\section{BMDCs Transduction and Transfer}

Bone marrow cells were isolated from tibia and femur of adult mice from 5-7 week old mice as previously described (90)and then cultured in DC media (RPMI 1640 (HyClone) supplemented with 10\% heat-inactivated fetal bovine serum (FBS; Life Technologies, Carlsband, CA, USA), $100 \mathrm{U} / \mathrm{ml}$ penicillin (HyClone), $100 \mathrm{mg} / \mathrm{ml}$ streptomycin (HyClone), human FLT3 200 ng/mL (Tonbo biosciences, San Diego, CA, USA) for 6 days at a density of $1 \times 10^{6}$ per $\mathrm{mL}$ in a 6 well plate. BMDCs were then harvested and infected with 3rd generation lentiviral vectors (pLV-IL-4R $\alpha$-eGFP or control pLV-eGFP) ( Cyagen biosciences Inc, CA, USA) at a multiplicity of infection (MOI) 20 in Opti-MEM media (Life Technologies) and $5 \mu \mathrm{g} / \mathrm{ml}$ of polybrene (Cyagen biosciences Inc) for 3 hours. These cells were then cultured in DC media for 4 days. Transduced cells were then infected with RSV at MOI 50 overnight, and CD11 $\mathrm{b}^{+} \mathrm{mDCs}$ $\left(\mathrm{CD} 11 \mathrm{c}^{+} \mathrm{MHCII}^{\mathrm{hi}} \mathrm{CD} 11 \mathrm{~b}^{+}\right.$) were sorted using SH800 cell sorter (Sony Biotechnology Inc., San Jose, CA, USA). These cells were adoptively transferred intranasally into the lungs of mice ( $1 \times 10^{5}$ cells in $50 \mu 1$ of SFM media). Control mice received $50 \mu 1$ of SFM media.

\section{RSV Gene Expression in the Lung}

RSV gene expression in the lungs was quantified using real-time RT-PCR that correlates well with plaque assay or TCID50 assay $(52,86,91)$. Lungs were isolated and total RNA was extracted using the Total RNA extraction kit (Qiagen; Valencia, CA, USA) according to the manufacturer's instructions. cDNA was synthesized using Oligo (dT) and SuperScript III first-strand synthesis system (Life Technologies; Carlsbad, CA, USA). Real-time PCR was performed using Platinum ${ }^{\circledR}$ SYBR ${ }^{\circledR}$ Green qPCR Supermix (Life Technologies) with the following primers:

NS1 forward primer (5'-CACAACAATGCCAGTGCTACAA-3')

NS1 reverse primer (5'-TTAGACCATTAGGTTGAGAGCAATGT-3')

\section{Cell Staining and Flow Cytometry}

To measure the expression of surface markers on pulmonary DCs, single cell suspensions were prepared from mouse lungs using gentleMACS ${ }^{\mathrm{TM}}$ Octo dissociator (Miltenyi Biotec Inc., San Diego, CA, USA) using standard protocol (86). Briefly, lungs were perfused and dissociated using gnetleMACS then digested using $1 \mathrm{mg} / \mathrm{ml}$ collagenase I (Invitrogen; Thermo Fisher Scientific; Logan, UT, USA), and $150 \mu \mathrm{g} / \mathrm{ml}$ 
DNase I (Sigma-Aldrich; St. Louis, MO, USA) by incubating at the $37^{\circ} \mathrm{c}$ incubator. Cell clumps and debris was removed by filtering through a $40 \mu \mathrm{m}$ cell strainer (BD Biosciences, San Jose, CA, USA). Red blood cells were lysed using 1X RBC lysis buffer (eBioscience, San Diego, CA, USA) and then filtered again through $35 \mu \mathrm{m}$ cell strainer to get single cell suspension. Single cell suspensions were kept on RPMI-1640 (HyClone) containing 10\% heat-inactivated fetal bovine serum (FBS; Life Technologies), $100 \mathrm{U} / \mathrm{ml}$ penicillin (HyClone), $100 \mathrm{mg} / \mathrm{ml}$ streptomycin (HyClone).A million cells were used for staining per animal, cells were counted using Acridine Orange/Propidium Iodide (AO/PI) stain and Cellometer (Nexcelom Bioscience LLC, Lawrence, MA, USA) Single cells were then stained with fixable viability dyes, antibodies to CD11c (N418), CD11b (M1/70; Biolegend, San Diego, CA,USA), CD103 (2E7), PDCA-1 (eBio 927), IL-4R $\alpha$ (mIL-4R-M1; BD Biosciences), MHCII (M5/114.15.2), CD80 (16-10A1), and CD86 (GL-1). All antibodies and dyes were from eBiosciences unless otherwise stated. The staining data were acquired on a FACS Canto II (BD Biosciences) flow cytometer and analyzed with FlowJo software (version 10; Tree Star; Ashland, OR, USA.). Since the mean fluorescence intensity (MFI )of IL-4R $\alpha$ fluorescence minus one (FMO) controls were different among the mice at different ages (i.e., 1 day, 5 days, and 6 weeks old), the IL-4R $\alpha$ MFI was normalized by subtracting MFI of the age-matched FMO controls from the actual values.

To measure the T cell profile in the lung, single cells from lungs were isolated as aforementioned and stimulated for 5 hours at $37^{\circ} \mathrm{C}$ in RPMI-1640 (HyClone) containing $10 \%$ heat-inactivated fetal bovine serum (FBS; Life Technologies), $100 \mathrm{U} / \mathrm{ml}$ penicillin (HyClone), $100 \mathrm{mg} / \mathrm{ml}$ streptomycin (HyClone), $5 \mathrm{ng} / \mathrm{ml}$ phorbol-12-myristate-13-acetate (PMA; Sigma-Aldrich), $500 \mathrm{ng} / \mathrm{ml}$ ionomycin (Sigma-Aldrich), and protein transport inhibitor $\left(1 \mu 1 / 10^{6}\right.$ cells; GolgiPlug, BD Biosciences). Cells were then stained with fixable viability dye, fixed with fixation buffer, permeabilized with permeabilization buffer, and labeled with antibodies to CD3 (17A2), CD4 (RM4-5; Biolegend), IFN $\gamma$ (XMG1.2), and IL-4 (BVD6-24G2). All antibodies, dyes, and buffers were from eBiosciences unless otherwise stated. Flow data were then acquired and analyzed as aforementioned. Cells were gated on lymphocytes based on FSC/SSC properties, singlets, live cells, and then on the CD3 and CD4 double positive population.

\section{Bronchoalveolar Lavage Fluid (BALF) Cellularity}

BALF was isolated using $1 \mathrm{ml}$ of PBS with $0.5 \%$ BSA. Cells were then counted using cellometer as mentioned previously. 20,000 cells from BALF were centrifuged onto slides using a cytospin. Cells were allowed to air -dry and stained with Hema-3 staining kit (Thermo Fisher Scientific). Cells were then differentiated and 200 cells were counted for each animal by an unbiased observer using an EVOS microscope (Life Technologies; Thermo Fisher Scientific). 


\section{Pulmonary Function Test}

Airway resistance was assessed using the FlexiVent FX system (Scireq, Montreal, Canada) to increasing doses $(0,12.5,25,50 \mathrm{mg} / \mathrm{ml})$ of methacholine (Sigma-Aldrich). Mice were anesthetized with ketamine/xylazine $(180 / 10 \mathrm{mg} / \mathrm{kg})$ and mechanically ventilated at a tidal volume of $10 \mathrm{ml} / \mathrm{kg}$ and a frequency of $2.5 \mathrm{~Hz}$ using a computercontrolled piston ventilator. Resistance was calculated by recording pressure and volume of the airways using the single compartment model. All data were normalized to their individual baseline resistance values ((value-baseline)/baseline) and plotted as normalized resistance.

\section{Lung Histopathology}

Following euthanasia, hearts of mice were perfused with PBS and lungs were removed and gravity inflated with zinc formalin (Thermo Fisher Scientific) and then fixed for 24 hours. Lung tissues were then embedded in paraffin, sectioned, and stained with hematoxylin and eosin (H\&E) or periodic acid-Schiff (PAS). Stained lung sections were visualized and images acquired using an EVOS microscope. Inflammation was semiquantitatively scored based on the following scale: 1-very mild, 2-mild, 3-moderate, 4 -severe in a blinded fashion. PAS staining was scored by a quantitative method (92).

\section{Cytokines in the Lung}

Cytokine levels, including IL-4, IL-12(p40), and IFN- $\gamma$, were measured in the BALF using a Milliplex kit (Millipore, Billerica, MA, USA) and Luminex system (Luminex; Austin, TX, USA) as per the manufacturer's instruction. Each sample was analyzed in duplicate. Raw data were plotted against a standard curve to interpolate unknowns via logistic regression. Values below the sensitivity of the assay were excluded from the graph.

For IL-13 cytokine; lungs were isolated and quick froze using liquid nitrogen for later analysis. Frozen lungs were then homogenized using homogenizer and Tissue protein extraction solution (Thermo Fisher Scientific) with protease inhibitor(Thermo Fisher Scientific).The solution was spun down to collect supernatant, and protein concentration was measured using Pierce ${ }^{\mathrm{TM}}$ BCA Assay Kit (Thermo Fisher Scientific). IL-13 in the lung homogenates was then quantified using a Mouse IL-13 Platinum ELISA kit (eBioscience). The detection limits for IL-4, IL-12(p40), IFN- $\gamma$, and IL-13 were 0.4, $4.9,0.9$, and $2.8 \mathrm{pg} / \mathrm{ml}$ respectively.

\section{In vitro T Cell Activation Assay}

Pulmonary $\mathrm{CD} 11 \mathrm{~b}^{+} \mathrm{mDCs}\left(\mathrm{CD} 11 \mathrm{c}^{+} \mathrm{MHCII}^{+} \mathrm{CD} 11 \mathrm{~b}^{+}\right)$were isolated first using CD11c Positive Selection Kit (Stemcell Technologies, Vancouver, Canada) and then 
SH800 cell sorter (Sony Biotechnology Inc., San Jose, CA, USA) from lungs of neonatal mice 6 days post infection with RSV. CD4 ${ }^{+} \mathrm{T}$ cells were isolated from the spleen of naïve adult BALB/c mice with CD4 positive selection kit (Stemcell Technologies) and stained with $0.5 \mu \mathrm{M}$ CFSE (Life Technologies). CFSE stained CD4 $4^{+}$cells $\left(1 \times 10^{5}\right)$ were then cocultured with $\mathrm{CD} 11 \mathrm{~b}^{+} \mathrm{mDCs}\left(2 \times 10^{4}\right)$ in the presence of $1 \mu \mathrm{g} / \mathrm{ml} \mathrm{CD} 3$ antibody (17A2; eBiosciences) for 72 hours. Cells were stimulated, stained, and analyzed by flow cytometry to determine the Th subpopulations. The purity of isolated $\mathrm{CD} 11 \mathrm{~b}^{+} \mathrm{mDCs}$ or $\mathrm{CD} 4^{+}$cells was greater than 90 percentage.

\section{Statistical Analyses}

Data were plotted as means \pm SEM and analyzed using GraphPad Prism 6 (GraphPad; La Jolla, CA, USA). Student's t-test or Two-way ANOVA with Bonferroni posthoc tests were used to compare the means among groups, where appropriate. Differences were considered statistically significant if $\mathrm{p}<0.05$.

\section{Results}

\section{Expression of IL-4Ra on Dendritic Cells Was Age Dependent}

In our previous study, we observed that the most significant downregulation of IL-4R $\alpha$ following ASO treatment occurred in pulmonary DCs, and this downregulation correlated with decreased Th2-biased immunopathologies during RSV reinfection (51). To explore the role of IL-4R $\alpha$ on $\mathrm{mDCs}$, we first quantified its expression on various types of pulmonary DCs from mice at different ages using gating strategy: in (Figure 2-1). Specifically, we measured expression of IL-4R $\alpha$ on pulmonary CD $11 \mathrm{~b}^{+} \mathrm{mDCs}$ $\left(\mathrm{CD} 11 \mathrm{c}^{+} \mathrm{MHCII}^{+} \mathrm{CD} 11 \mathrm{~b}^{+}\right), \mathrm{CD} 103^{+} \mathrm{mDCs}\left(\mathrm{CD} 11 \mathrm{c}^{+} \mathrm{MHCII}^{+} \mathrm{CD} 103^{+}\right)$, and $\mathrm{pDCs}$ $\left(\mathrm{CD} 11 \mathrm{c}^{+} \mathrm{PDCA}-1^{+}\right)$from neonatal ( 1 or 5 days old) or adult mice (6 weeks old) via flow cytometry (Figure 2-2A). The expression of IL-4R $\alpha$ on $\mathrm{CD}_{11} \mathrm{~b}^{+} \mathrm{mDCs}$ declined as age increased, with 1 day old pups expressing the highest level (Figure 2-2B). Interestingly, IL-4R $\alpha$ expression on $\mathrm{CD}_{103^{+}} \mathrm{mDC}$ increased with age, with adults expressing the highest level (Figure 2-2C). Similar to CD1 $1 b^{+}$mDCs, pDCs downregulated IL-4R $\alpha$

expression while age increased (Figure 2-2D). These data suggest that the expression of IL-4R $\alpha$ on pulmonary DCs is developmentally regulated and cell-specific.

\section{Deletion of IL-4R $\alpha$ on CD11 ${ }^{+}$Cells Attenuated Th2-biased Immune Responses upon RSV Reinfection}

Having confirmed that neonatal CD $11 \mathrm{~b}^{+} \mathrm{mDCs}$ express elevated levels of IL-4R $\alpha$, we further examined the role of IL-4R $\alpha$ on $\mathrm{CD}_{11} \mathrm{~b}^{+} \mathrm{mDCs}$ in polarizing the Th2-biased immune response to RSV. We used a mouse model in which IL-4R $\alpha$ is specifically 

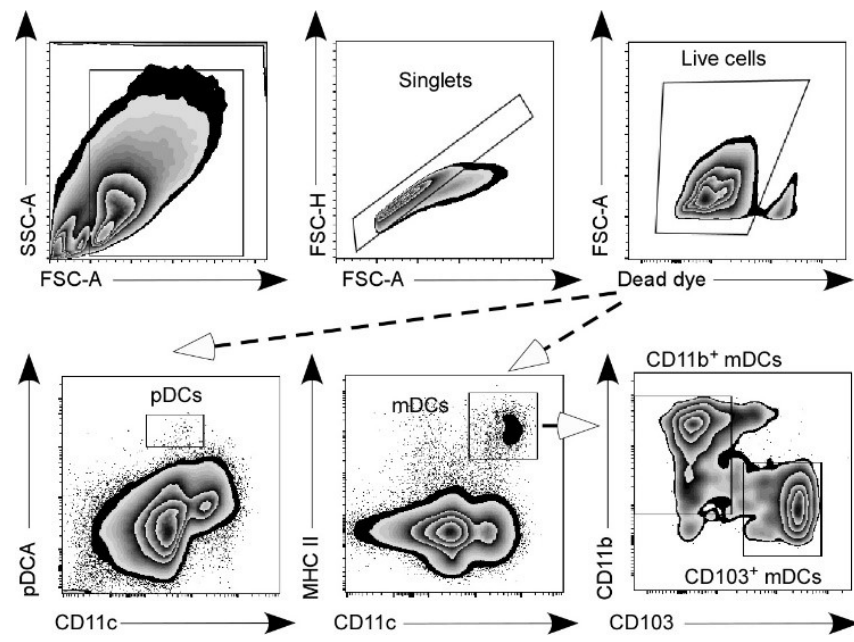

Figure 2-1. Gating strategy for pulmonary DCs.

Single, live cells were first gated. $\mathrm{mDCs}$ were defined as $\mathrm{CD}_{11} \mathrm{c}^{+} \mathrm{MHCII}^{+}$cells and further categorized into $\mathrm{CD} 11 \mathrm{~b}^{+}$and $\mathrm{CD} 103^{+} \mathrm{mDCs}$. pDCs were identified as

CD $11 \mathrm{c}^{+}$PDCA- $1^{+}$cells. The figure shown was a representative of lung cells from 1 day old pups. All gates were consistent among mice of different ages (i.e., 1 day, 5 days, or 6 weeks old). 


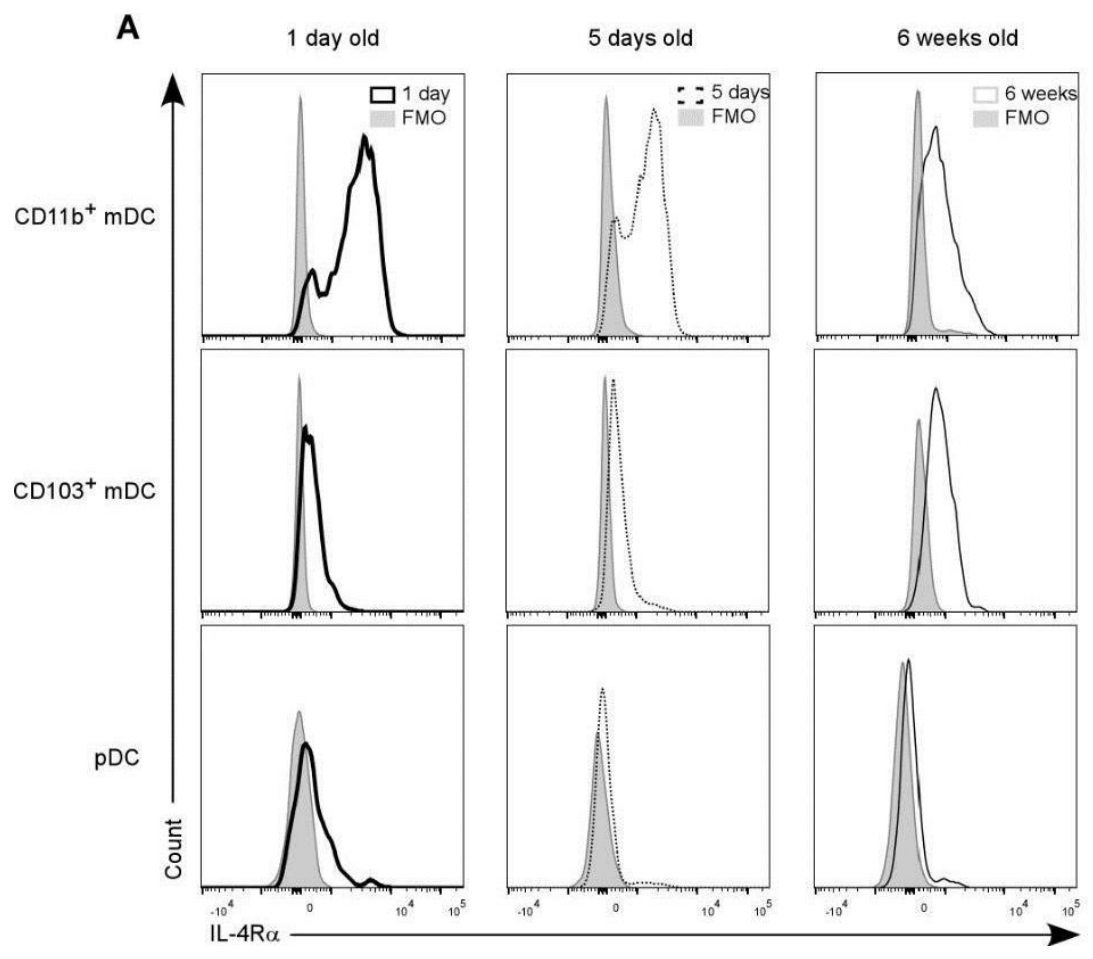

B
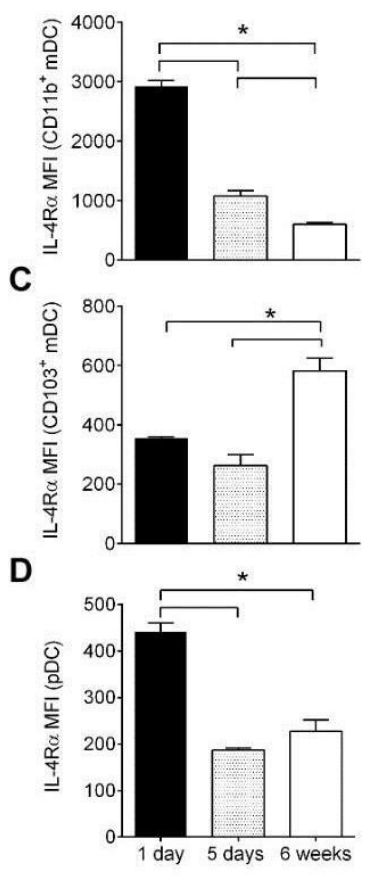

Figure 2-2. Expression of IL-4R $\alpha$ on dendritic cells was age dependent.

Lung DCs from neonatal ( 1 or 5 days old) or adult mice (6 weeks old) were analyzed by flow cytometry for the surface expression of IL-4R $\alpha$. (A)Flow cytometric histogram graphs showing a representative example of IL-4R $\alpha$ expression on DC subsets.(B) IL4R $\alpha$ MFI on CD $11 b^{+}$mDCs. (C) IL-4R $\alpha$ MFI on CD $103^{+}$mDCs. (D) IL-4R $\alpha$ MFI on pDCs. $\mathrm{MFI}=$ mean fluorescence intensity. Shaded histograms represent FMO controls. Data are representative of 3 independent experiments with four to five mice per group; $* \mathrm{p}<0.05$. 
deleted on CD11 $\mathrm{c}^{+}$cells (IL-4R ${ }^{-/ \text {DC }}$ ) by crossing IL-4R $\alpha^{\text {lox/lox }}$ mice with CD $11 \mathrm{cCre}$ IL$4 \mathrm{R} \alpha^{-/}$mice. In these mice, the expression of IL-4R $\alpha$ is decreased on mDCs and alveolar macrophages, but not on T cells (Figure 2-3). The littermate controls (IL-4R $\alpha^{-/ 10 x} \mathrm{DC}$ ) have one copy of intact IL-4R $\alpha$. IL-4R $\alpha^{-/-D C}$ and IL-4R $\alpha^{-1 / 0 x}$ DC neonatal mice were infected with RSV (IL-4R $\alpha^{-/-D C}$ RR and IL-4R $\alpha^{-/ 10 x}$ DC RR) or media (IL-4R $\alpha^{-/-D C}$ Sham or IL-4Ro ${ }^{-/ 10 x \mathrm{DC}}$ Sham) at 5 days of age and reinfected at 4 weeks post primary infection. At 6 days post reinfection, we analyzed the $\mathrm{CD}^{+} \mathrm{T}$ cell responses from the lungs of these mice. As expected, the IL-4R $\alpha^{-1 / \text { Dx DC }} \mathrm{RR}$ mice that had one copy of intact Il-4R $\alpha$ mounted a Th2-biased immune response upon RSV reinfection, although the magnitude of this Th2-bias was smaller than BALB/c mice as previously published (51). More importantly, we observed a significant decrease in the percentage of CD4 $4^{+}$IL- $4^{+} \mathrm{T}$ cells in the IL-4R $\alpha$ ${ }^{1-D C} \mathrm{RR}$ mice compared to IL-4R $\alpha^{-/ 10 x} \mathrm{DC}$ RR mice (Figure 2-4A). There was also a reduction in $\mathrm{CD} 4^{+} \mathrm{IFN}-\gamma^{+} \mathrm{IL}-4^{+} \mathrm{T}$ cells in IL-4R $\alpha^{-/-\mathrm{DC}} \mathrm{RR}$ mice vs. IL-4R $\alpha^{-/ 10 x \mathrm{DC}} \mathrm{RR}$ mice (Figure 2-4A).

This reduction in Th2 cells was accompanied with a decrease in the IL-13 (Table 2-1) in lung homogenates. IL-4 was very low in both groups. While no difference was observed in the percentage of $\mathrm{CD} 4^{+} \mathrm{IFN}-\gamma^{+} \mathrm{T}$ cells between the RSV infected groups, we did observe an elevation in IL-12p40 levels in the BALF of IL-4R $\alpha^{-/-D C} \mathrm{RR}$ mice vs. IL$4 \mathrm{R} \alpha^{-/ 10 x} \mathrm{DC}$ RR (Table 2-1). These results were not due to a difference in relative viral gene expression of RSV (Figure 2-4B) or baseline numbers of DCs during initial infection (Figure 2-5). These data indicate that IL-4R $\alpha$ on $\mathrm{CD}_{1} 1 \mathrm{~b}^{+} \mathrm{mDCs}$ plays a role in the Th2-biased immune response to neonatal RSV infection in vivo.

\section{Deletion of IL-4R $\alpha$ on CD11 $\mathrm{c}^{+}$Cells Protected Mice from Immunopathophysiology upon RSV Reinfection}

In addition to the pulmonary $\mathrm{CD} 4^{+} \mathrm{T}$ cell responses, we also examined pathophysiological endpoints including BALF cellularity and pulmonary function and pathology in IL-4R $\alpha^{-/ \text {DC }} \mathrm{RR}$ and IL-4R $\alpha^{-/ / o x} \mathrm{DC} \mathrm{RR}$ mice. We observed substantially reduced inflammatory responses in the airways of IL-4R $\alpha^{-/-D C} \mathrm{RR}$ mice as evidenced by reduced total cells, macrophages, and eosinophils in the BALF compared to IL- $4 \mathrm{R}^{-/ \mathrm{lox} \text { DC }}$ RR mice (Figure 2-6A). As shown in (Figure 2-6B), RSV induced airway hyperreactivity (AHR) in IL-4R $\alpha^{-/ 10 x}$ DC $R R$ mice, whereas airway resistance in IL-4R $\alpha^{-/ 2}$ ${ }^{D C}$ RR mice was no different than sham controls. No significant differences in resistance were detected between groups of sham infected mice. Peribronchiolar and perivascular inflammation were significantly reduced in IL-4R $\alpha^{-/-D C} \mathrm{RR}$ vs. IL-4R $\alpha^{-1 / 0 x} \mathrm{DC} R \mathrm{RR}$ mice (Figure 2-6C). Strikingly, there was little-to-no mucus production in the airways of IL$4 \mathrm{R} \alpha^{-/-D C} \mathrm{RR}$, while significant amounts of airway mucus were obvious in IL-4R $\alpha^{-/ 10 x} \mathrm{DC}$ RR mice (Figure 2-6D). This observation is consistent with the fact that airway resistance in IL-4R $\alpha^{-/-D C} \mathrm{RR}$ mice was no different from sham-infected mice. The decrease in airway inflammation, AHR, and mucus hyperproduction in IL-4R $\alpha^{-/ \text {DC }} \mathrm{RR}$ mice suggests that elevated IL-4R $\alpha$ expression on $\mathrm{CD} 11 \mathrm{~b}^{+} \mathrm{mDCs}$ is partially responsible for the immunopathophysiology upon RSV reinfection. 


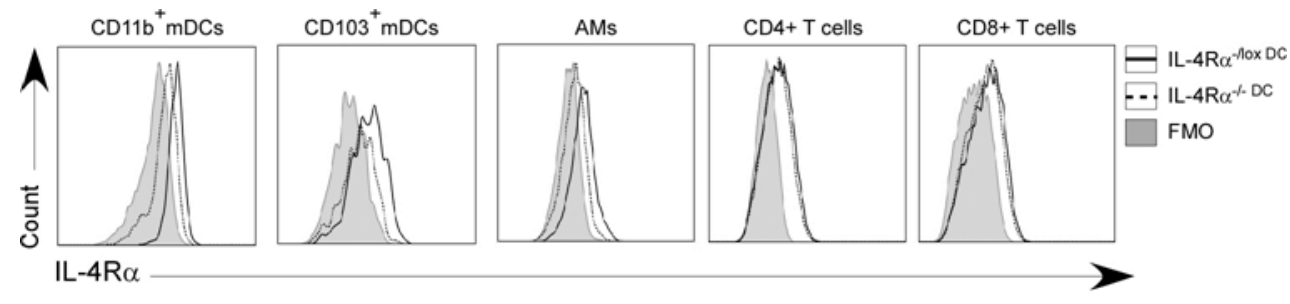

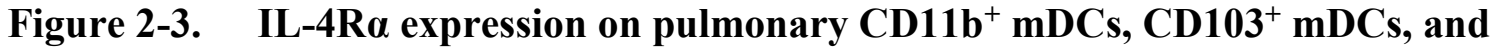
AMs was decreased in CD11 ${ }^{+}$specific, IL-4R $\alpha$ deficient mice.

IL-4R $\alpha^{-/-D C}$ and IL-4R $\alpha^{-/ 10 x ~ D C}$ mice at 5 days of age were infected with RSV; and IL-4R $\alpha$ expression at 4 dpi was measured via flow cytometry on pulmonary $\mathrm{CD} 11 \mathrm{~b}^{+} \mathrm{mDCs}$ $\left(\mathrm{CD} 11 \mathrm{c}^{+} \mathrm{MHCII}^{+} \mathrm{F} 4 / 80^{-} \mathrm{CD} 11 \mathrm{~b}^{+}\right), \mathrm{CD} 103^{+} \mathrm{mDCs}\left(\mathrm{CD} 11 \mathrm{c}^{+} \mathrm{MHCII}^{+} \mathrm{F} 4 / 80^{-} \mathrm{CD}^{-03}{ }^{+}\right)$, alveolar macrophages (AMs, $\left.\mathrm{CD} 11 \mathrm{c}^{+} \mathrm{F} 4 / 80^{+}\right), \mathrm{CD}^{+} \mathrm{T}$ cell, and $\mathrm{CD} 8^{+} \mathrm{T}$ cells. $\mathrm{n}=3$ mice per group. 
A
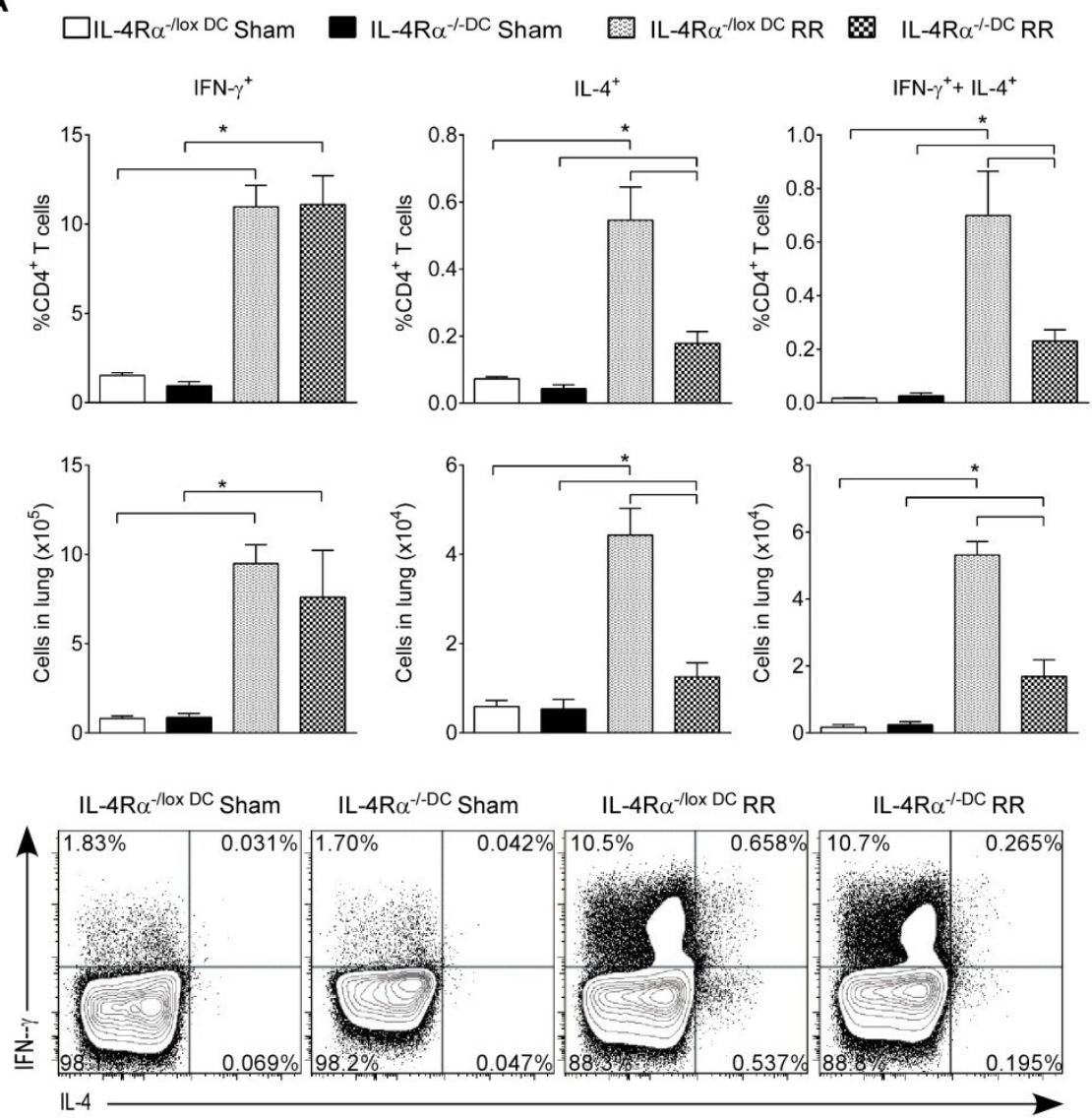

B

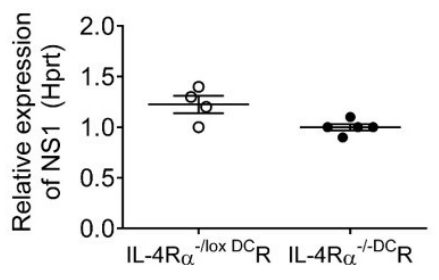

Figure 2-4. Deletion of IL-4R $\alpha$ on CD11 ${ }^{+}$cells attenuated Th2-biased immune responses upon $\mathrm{RSV}$ reinfection.

IL-4R $\alpha^{-/-D C}$ or IL-4R $\alpha^{-/ l o x ~ D C}$ mice were infected at 5 days of age and reinfected with RSV 4 weeks later (IL-4R $\alpha^{-/-D C} \mathrm{RR}$ and IL-4R $\alpha^{-/ 10 x \mathrm{DC}} \mathrm{RR}$, respectively). Control mice were sham infected (IL-4R $\alpha^{-/-D C}$ Sham and IL-4R $\alpha^{-/ l o x}$ DC Sham). Pulmonary Th profile was measured via flow cytometry at 6 days post-reinfection and viral gene expression via real-time RT-PCR at 4 days post primary infection was calculated. (A) Percentage (upper panel) and numbers (middle panel) of pulmonary $\mathrm{CD}^{+} \mathrm{T}$ cells expressing IFN- $\gamma$, IL-4, or both IFN- $\gamma$ and IL-4. The bottom panel displays representative flow plots. (B) Relative expression of RSV NS1 gene in the lung at 4 days post primary infection. Data are representative of 3 independent experiments with four to five mice per group; ${ }^{*} \mathrm{p}<0.05$. 
Table 2-1. Deletion of IL-4R $\alpha$ on CD11 ${ }^{+}$cells attenuated Th2-biased cytokine responses in the lung upon RSV reinfection.

\begin{tabular}{|c|c|c|c|c|}
\hline $\begin{array}{l}\text { Cytokines } \\
(\mathrm{pg} / \mathrm{ml})\end{array}$ & $\begin{array}{c}\text { IL-4R } \alpha^{-/ 10 x ~ D C} \\
\text { Sham }\end{array}$ & $\begin{array}{c}\text { IL-4R } \alpha^{-/-D C} \\
\text { Sham }\end{array}$ & $\begin{array}{c}\mathrm{IL}-4 \mathrm{R} \alpha^{-/ 10 x \mathrm{DC}} \\
\mathrm{RR}\end{array}$ & $\begin{array}{c}\mathrm{IL}-4 \mathrm{R} \alpha^{-/-\mathrm{DC}} \\
\mathrm{RR} \\
\end{array}$ \\
\hline IFN- $\gamma$ & B.D. & B.D. & $51.9 \pm 15.9$ & $88.9 \pm 14.4$ \\
\hline IL-4 & B.D. & B.D. & $1.1 \pm 0.2$ & $1.2 \pm 0.2$ \\
\hline IL-12p40 & B.D. & B.D. & $9.2 \pm 3.4$ & $21.0 \pm 4.3^{*}$ \\
\hline IL-13 & $21.0 \pm 2.1$ & $19.3 \pm 4.5$ & $27.7 \pm 1.6^{\#}$ & $18.9 \pm 2.1^{*}$ \\
\hline
\end{tabular}

Notes: IL-4R $\alpha^{-/ 10 x ~ D C}$ or IL-4R $\alpha^{-/-D C}$ mice were infected at 5 days of age and reinfected with RSV 4 week later (IL-4R $\alpha^{-/ 10 x ~ D C} \mathrm{RR}$ or IL-4R $\alpha^{-/-D C} \mathrm{RR}$, respectively). Control mice received serum-free viral growth media (IL-4R $\alpha^{-/ l o x ~ D C}$ Sham or IL-4R $\alpha^{-/-D C}$ Sham). Cytokines were measured in BALF (IFN- $\gamma$, IL-4, and IL-12p40) or lung homogenates (IL-13) at 6 days post reinfection and are reported in $\mathrm{pg} / \mathrm{ml} . \mathrm{n}=4-5$ mice per group, ${ }^{*} \mathrm{p}<0.05$ vs. IL-4R $\alpha^{-/ / \mathrm{lox} D C} \mathrm{RR}$. ${ }^{*} \mathrm{p}<0.05$ vs. IL-4R $\alpha^{-/ \mathrm{lox} \text { DC }}$ Sham or IL-4R $\alpha^{-/- \text {DC }}$ Sham. B.D.: below the detection limit. 


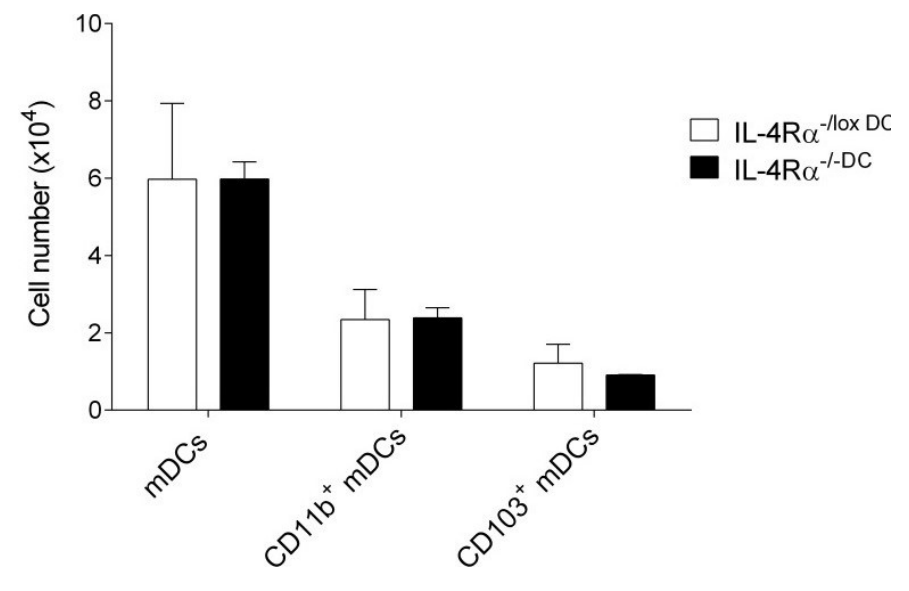

Figure 2-5. The amount of $\mathrm{mDCs}, \mathrm{CD}_{11 \mathrm{~b}^{+}} \mathrm{mDCs}$, and $\mathrm{CD} 103^{+} \mathrm{mDCs}$ did not change in $\mathrm{CD}_{11 \mathrm{c}^{+}}$specific, IL-4R $\alpha$ deficient mice. The amount of mDCs $\left(\mathrm{CD} 11 \mathrm{c}^{+} \mathrm{MHCII}{ }^{+}\right), \mathrm{CD} 11 \mathrm{~b}^{+} \mathrm{mDCs}\left(\mathrm{CD} 11 \mathrm{c}^{+} \mathrm{MHCII} \mathrm{C}^{+} \mathrm{CD} 11 \mathrm{~b}^{+}\right)$, $\mathrm{CD} 103^{+} \mathrm{mDCs}\left(\mathrm{CD} 11 \mathrm{c}^{+} \mathrm{MHCII}{ }^{+} \mathrm{CD} 103^{+}\right)$was quantified in 5 days old, $\mathrm{CD} 11 \mathrm{c}^{+}$specific, IL-4R $\alpha$ deficient mice (IL-4R $\alpha^{-/-\mathrm{DC}}$ ) and their littermates (IL-4R $\left.\alpha^{-/ 10 x} \mathrm{DC}\right)$ via flow cytometry. $\mathrm{n}=3-4$ mice per group. 
A

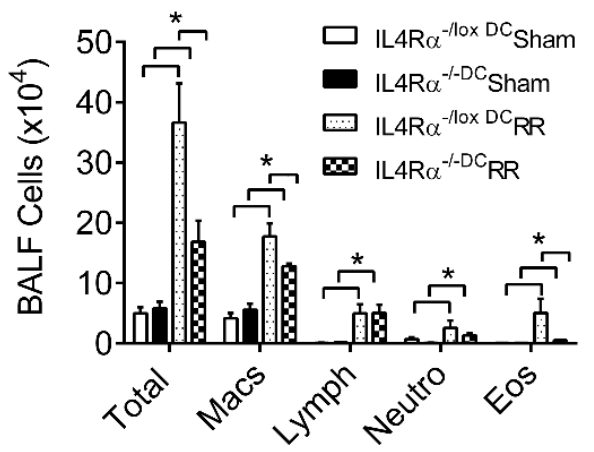

C

$\mathrm{IL}-4 \mathrm{R} \alpha^{-1 / 10 x} \mathrm{DC} R \mathrm{RR}$

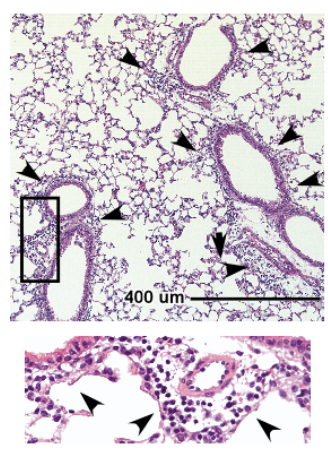

$\mathrm{IL}-4 \mathrm{R} \alpha^{-1-\mathrm{DC}} \mathrm{RR}$

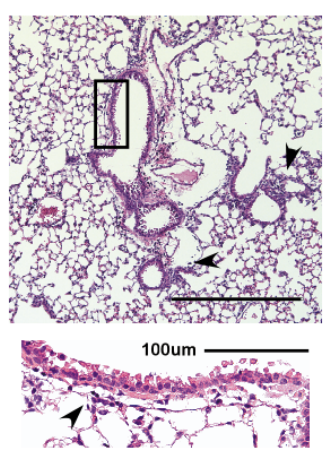

B

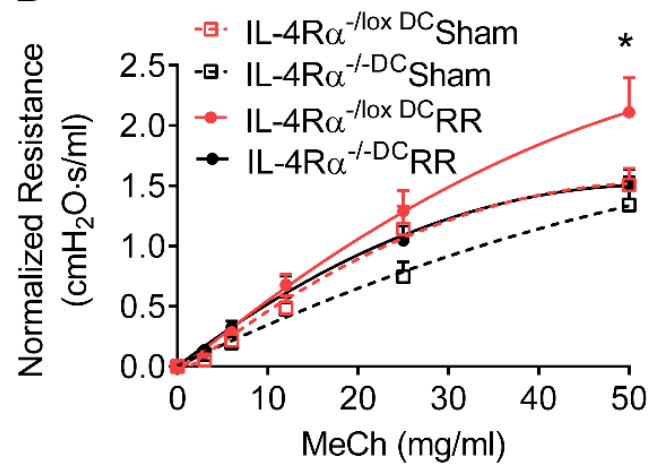

D
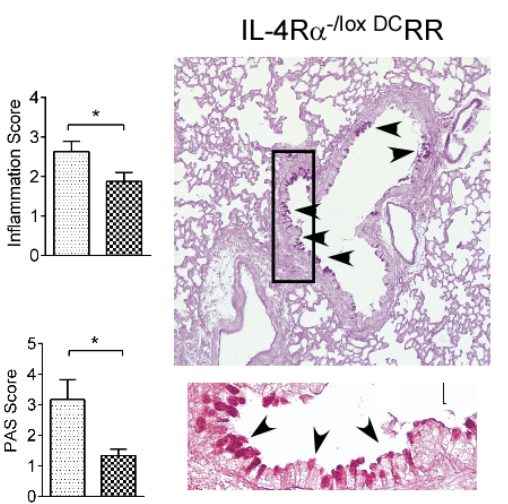

Figure 2-6. Deletion of IL-4Ra on $\mathrm{CD}_{11 b^{+}} \mathrm{mDCs}$ protected mice from immunopathophysiology upon RSV reinfection.

IL-4R $\alpha^{-/-D C}$ or IL-4R $\alpha^{-/ l o x ~ D C}$ mice were infected and reinfected with RSV as previously described. BALF cellularity, airways resistance in response to methacholine challenge, and histology were performed at 6 days post-reinfection. (A) BALF cellularity. Macs: macrophages, Lymph: lymphocytes, Neutro: neutrophils, Eos: eosinophils. (B) Airway resistance. (C) H\&E stained lung sections and inflammation score. Arrowheads point to cellular infiltrates. (D) PAS stained lung sections and PAS score. Arrowheads point to mucus. Scale bar $=400 \mu \mathrm{m}$ in the upper panels. The bottom panels are images taken under higher magnification of the selected area in the upper panel (inset box). Scale bar $=$ $100 \mu \mathrm{m}$ in the bottom panels. Data are representative of 2 independent experiments with four to five mice per group; ${ }^{*} p<0.05$. 


\section{Absence of IL-4R $\alpha$ on CD11 ${ }^{+}$mDCs Dampened Th2 Responses to RSV Infection in vitro}

While the expression of IL-4R $\alpha$ was decreased on neonatal CD $11 b^{+}$mDCs in the IL-4R $\alpha^{-/-D C}$ mice, it was also decreased on $\mathrm{CD} 103^{+} \mathrm{mDCs}$ and alveolar macrophages (Figure 2-3). To examine the role of IL-4R $\alpha$ specifically on $\mathrm{CD}_{11} \mathrm{~b}^{+} \mathrm{mDCs}$ to induce Th2biased immune response to RSV, we performed in vitro T cell activation assays. Pulmonary $\mathrm{CD}_{11} \mathrm{~b}^{+} \mathrm{mDC}$ s were isolated from RSV-infected neonatal IL-4R $\alpha^{-/ \text {DC }}$ or IL$4 \mathrm{R} \alpha^{-/ l o x} \mathrm{DC}$ mice. These cells were subsequently co-cultured for 3 days with splenic $\mathrm{CD} 4^{+}$ $\mathrm{T}$ cells isolated from naïve adult BALB/c mice, and T cell phenotypes were then measured by flow cytometry. As expected, neonatal CD $11 \mathrm{~b}^{+} \mathrm{mDC}$ from IL-4R $\alpha^{-/ \mathrm{lox} \mathrm{DC}}$ mice induced a substantial amount of Th2 cells $\left(\mathrm{CD} 4^{+} \mathrm{IL}-4^{+}\right)$; and mimicking our in vivo data, CD $11 \mathrm{~b}^{+} \mathrm{mDC}$ from IL-4R $\alpha^{-/-\mathrm{DC}}$ mice induced significantly less amount of Th2 cells (Figure 2-7B) and decreased ratio of Th2/Th1 $\left(\mathrm{CD} 4^{+} \mathrm{IL}-4^{+} / \mathrm{CD} 4^{+} \mathrm{IFN}-\gamma^{+}\right)$cells (Figure 2-7C). These data suggest that IL-4R $\alpha$ expression on $\mathrm{CD} 11 \mathrm{~b}^{+} \mathrm{mDC}$ promotes Th2-biased immune responses to RSV.

\section{Loss of IL-4R $\alpha$ Expression on CD11b ${ }^{+}$mDCs Enhanced Their Maturation}

To delineate the mechanism by which IL-4R $\alpha$ on $\mathrm{CD}_{11} \mathrm{~b}^{+} \mathrm{mDCs}$ induced Th2biased responses to RSV in neonates, we measured the expression of maturation markers (CD80 and CD86) on CD11 b ${ }^{+}$mDCs. Wild-type neonates (NR) and adults (AR) or IL-

$4 \mathrm{R} \alpha^{-/-D C}$ neonates (IL-4R $\alpha^{-/-D C} \mathrm{NR}$ ) were infected with RSV, and the expression of CD80 and CD86 was measured on pulmonary CD11 $\mathrm{b}^{+} \mathrm{mDCs}$ by flow cytometry. Consistent with previous studies $(29,71)$, neonatal $\mathrm{CD} 11 \mathrm{~b}^{+} \mathrm{mDCs}$ were less mature (i.e. reduced expression of CD80 and CD86) compared to their adult counterparts during RSV infection (Figure 2-8A\& B). In the absence of IL-4R $\alpha$, the expression of CD80 and CD86 was significantly enhanced on $\mathrm{CD} 11 \mathrm{~b}^{+} \mathrm{mDCs}$ (IL-4R $\alpha^{-/ \text {DC }} \mathrm{NR}$ compared to NR mice; Figure 2-8A\&B). These data suggest that elevated expression of IL-4R $\alpha$ on neonatal

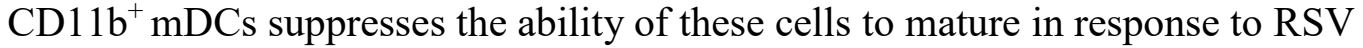
infection, resulting in Th2-biased adaptive immune response.

\section{Overexpression of IL-4Ra on Adult mDCs Exacerbated Th2 Responses to RSV Infection in vivo}

Expression of IL-4R $\alpha$ on $\mathrm{CD}_{1} 1 \mathrm{~b}^{+} \mathrm{mDC}$ declines significantly with age. To further confirm the pathogenic role of IL-4R $\alpha$, we overexpressed IL-4R $\alpha$ on adult mDCs. Specifically, we transduced adult bone marrow-derived dendritic cells (BMDCs) with IL4R $\alpha$ (pLV-IL-4R $\alpha$-eGFP) or eGFP (pLV-eGFP) expressing lentivirus. Successful transduction was verified using flow cytometry (Figure 2-9). CD11 $\mathrm{b}^{+} \mathrm{mDC}$ s that were positive for eGFP were then sorted and adoptively transferred to the lungs of naïve adult mice. One week later, these mice were infected with RSV. Six days post-infection, we analyzed pulmonary $\mathrm{CD}^{+} \mathrm{T}$ cell responses. Overexpression of IL-4R $\alpha$ on adult CD $11 \mathrm{~b}^{+}$ 

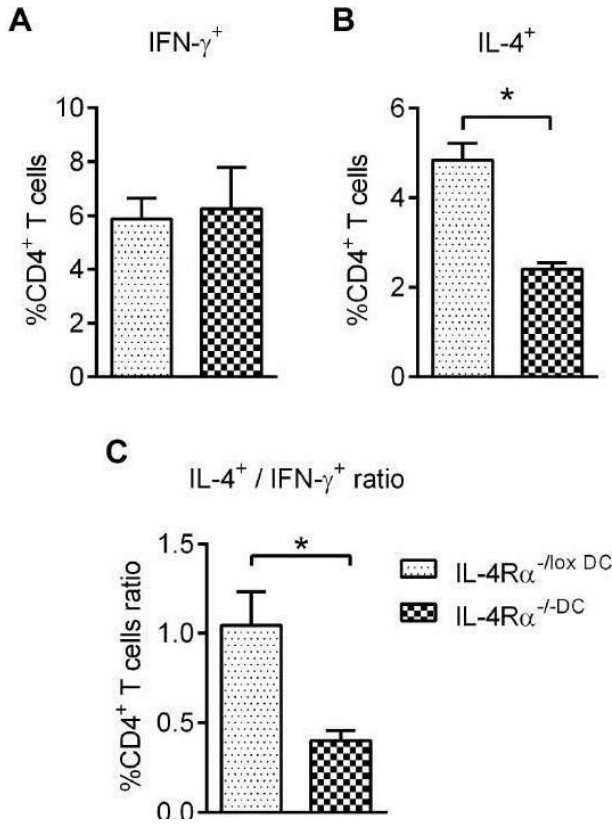

Figure 2-7. Absence of IL-4R $\alpha$ on $\mathrm{CD}_{11} \mathrm{~b}^{+}$mDCs dampened Th2 responses to RSV infection in vitro.

Neonatal IL-4R $\alpha^{-/-D C}$ and IL-4R $\alpha^{-/ 10 x ~ D C}$ were infected with RSV. CD11 b $\mathrm{b}^{+} \mathrm{mDC}$ were isolated from these mice at 6 days post infection and cultured with $\mathrm{CD}^{+}{ }^{+} \mathrm{T}$ cells purified from spleens of naïve, adult BALB/c mice. Th profile was measured after $72 \mathrm{hr}$ coculture using flow cytometry. (A) Percentage of pulmonary $\mathrm{CD}^{+} \mathrm{T}$ cells expressing IFN$\gamma$. (B) Percentage of pulmonary CD4 ${ }^{+} \mathrm{T}$ cells expressing IL-4. (C) Ratio of pulmonary $\mathrm{CD}^{+}{ }^{+} \mathrm{T}$ cells expressing IL-4 and IFN- $\gamma$. Data are representative of 2 independent experiments with three samples per group; ${ }^{*} \mathrm{p}<0.05$. 
A

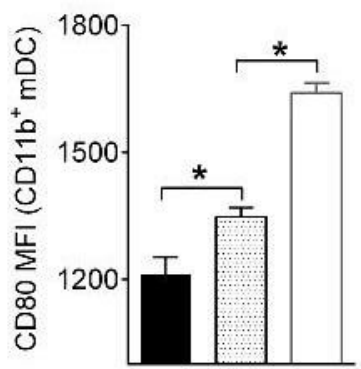

B

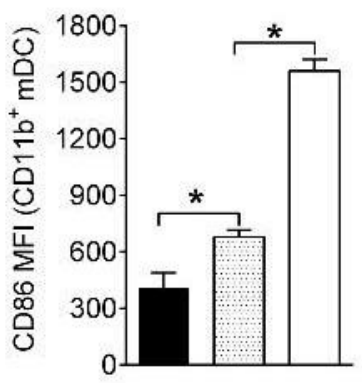

C

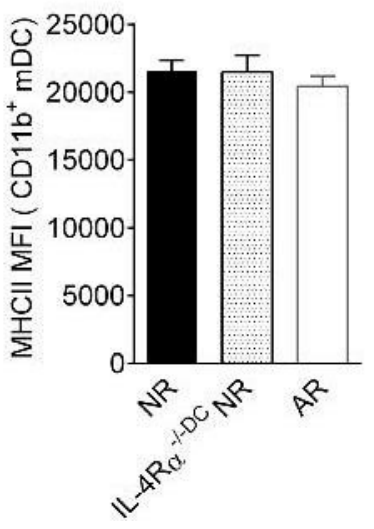

D

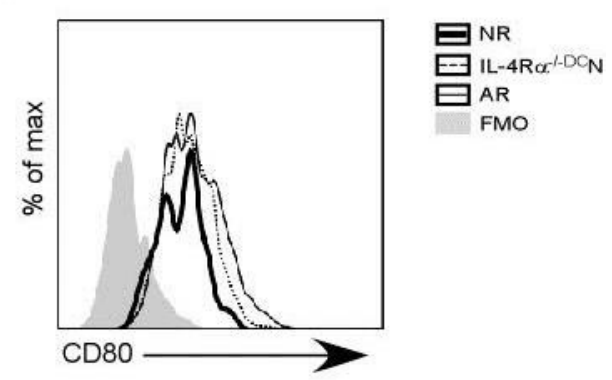

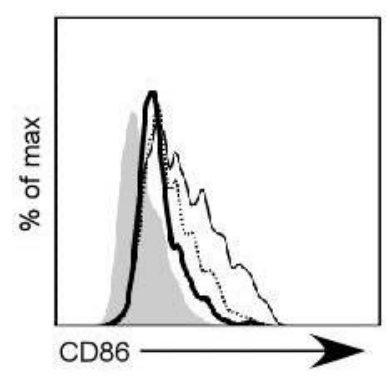

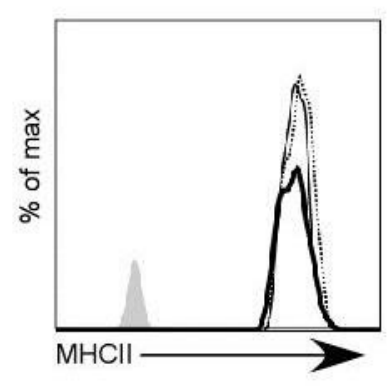

Figure 2-8. Loss of IL-4R $\alpha$ on $\mathrm{CD}_{11 \mathrm{~b}^{+}} \mathrm{mDCs}$ enhances their maturation response to RSV.

Neonatal or adult WT mice and neonatal IL-4R $\alpha^{-/-D C}$ mice were infected with RSV. Maturation markers (CD80 and CD86) and MHCII were measured on lung CD11b ${ }^{+}$ mDCs via flow cytometry. (A) MFI of CD80 on CD1 1 b ${ }^{+}$mDCs. (B) MFI of CD86 on CD1 $1 b^{+}$mDCs. (C) MFI of MHCII on CD11 $b^{+}$mDCs.(D) Flow cytometric histogram showing representative expression of CD80, CD86, and MHCII on CD11 b ${ }^{+} \mathrm{mDCs}$. Data are representative of 3 independent experiments with four to five mice per group; $* \mathrm{p}<0.05$. 

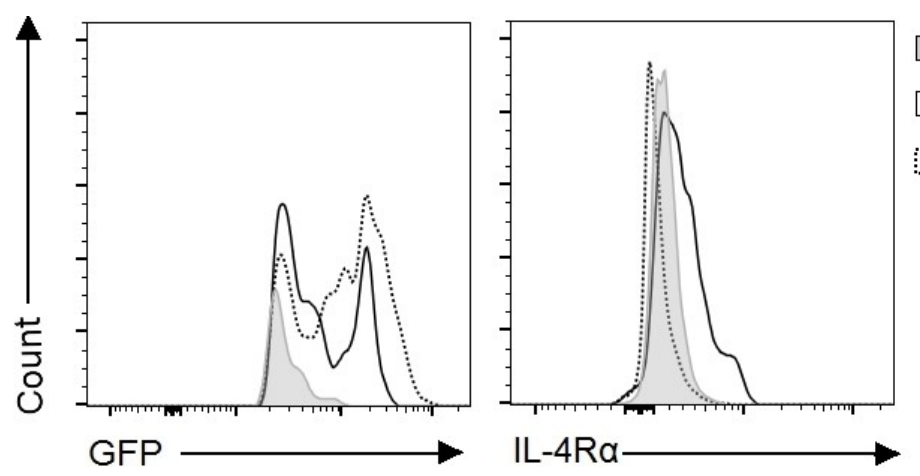

Untransfected

pLV-IL-4Ra-eGFP

pLV-eGFP

Figure 2-9. GFP and IL-4R $\alpha$ expression on BMDCs was increased after transduction.

BMDCs purified from adult mice were transduced with lentiviral vectors (either pLV-IL$4 \mathrm{R} \alpha$-eGFP or control pLV-eGFP), and GFP and IL-4R $\alpha$ expression was measured via flow cytometry 5 days post transduction. 
mDCs (pLV-IL-4R $\alpha$-eGFP) resulted in a lower percentage but no significant change in the number of $\mathrm{CD} 4^{+} \mathrm{IFN}-\gamma^{+} \mathrm{T}$ cells (Figure 2-10A\&B). A higher percentage and number of CD $4^{+} \mathrm{IL}_{-} 4^{+} \mathrm{T}$ cells were observed when IL-4R $\alpha$ was overexpressed on adult $\mathrm{CD} 11 \mathrm{~b}^{+}$ mDCs compared to the control groups (Figure 2-10A\&B). There was no change in the percentage of CD $4^{+} \mathrm{IFN}-\gamma^{+} \mathrm{IL}-4^{+}$cells with overexpression of IL-4R $\alpha$ on adult CD $11 \mathrm{~b}^{+}$ $\mathrm{mDCs}$, but there was an increase in the number of these cells (Figure 2-8B).

\section{Discussion}

Infants are particularly vulnerable to severe RSV infection; both human and animal studies implicate a Th2-biased immune response in the pathogenesis of RSV in infants $(42,43)$. In particular, single nucleotide polymorphisms in the IL-4R $\alpha$ gene that increase the receptor response to its cytokines (IL-4 or IL-13) are associated with increased IgE production, hospitalization rates due to RSV infection, and susceptibility to asthma $(79,93)$. Pharmacological downregulation of IL-4R $\alpha$ in the lung is protective against RSV disease in neonatal mice and effective in preventing Th2-biased immunopathogenesis (51). In the current study, we observed increased expression of IL$4 \mathrm{R} \alpha$ on pulmonary $\mathrm{CD}_{11} \mathrm{~b}^{+} \mathrm{mDC}$ in neonatal compared to adult mice. Deletion of IL$4 \mathrm{R} \alpha$ on neonatal CD11 $\mathrm{c}^{+}$cells (including $\mathrm{CD} 11 \mathrm{~b}^{+} \mathrm{mDCs}$ and other cells) resulted in a significant reduction in Th2 polarization, RSV-associated airway hyperreactivity, inflammation and eosinophilia following RSV reinfection in vivo. This was accompanied by an increase in IL-12 production. In vitro $\mathrm{T}$ cell activation assays demonstrated the specificity of IL-4R $\alpha$ on neonatal $\mathrm{CD} 11 \mathrm{~b}^{+} \mathrm{mDCs}$ in the induction of Th2 responses to RSV. Since adult CD $11 b^{+} \mathrm{mDCs}$ express significantly less IL-4R $\alpha$, complimentary experiments in which adult $\mathrm{CD}_{11 \mathrm{~b}^{+}} \mathrm{mDC}$ were made to overexpress IL-4R $\alpha$ were also performed. Overexpression of IL-4R $\alpha$ on adult $\mathrm{CD}_{11} \mathrm{~b}^{+}$mDCs and the transfer of these cells into the lungs of adult mice prior to RSV infection were able to recapitulate the Th2biased immunopathogenesis observed in neonatal mice. More mechanistically, we demonstrated that pulmonary $\mathrm{CD} 11 \mathrm{~b}^{+} \mathrm{mDCs}$ were less mature in neonates compared to adults in response to RSV infection and that deletion of IL-4R $\alpha$ on CD11 $\mathrm{b}^{+} \mathrm{mDCs}$ enhanced their maturation altering Th2/Th1 immune responses to RSV.

The maturation status of DCs is important for their function; and the costimulatory molecules, CD80 and CD86, are thought to be essential as the second signal for $\mathrm{T}$ cell activation. Here, we demonstrated that the level of CD80 and CD86 on $\mathrm{CD} 11 \mathrm{~b}^{+} \mathrm{mDC}$ s was associated with the axis of $\mathrm{CD}^{+} \mathrm{T}$ cell differentiation (i.e. Th1 vs. Th2). Neonatal CD11b ${ }^{+}$mDCs expressed less CD80 and CD86 than their adult counterparts (Figure 2-8A\&B) and induced fewer Th1 cells in response to RSV infection (52). Interestingly, $\mathrm{CD} 103^{+} \mathrm{mDCs}$, which mainly activate $\mathrm{CD} 8^{+} \mathrm{T}$ cells, have also been shown to be immature in neonates compared to adults; and the maturation status of $\mathrm{CD} 103^{+} \mathrm{mDCs}$ influences the epitope hierarchy of $\mathrm{CD} 8^{+} \mathrm{T}$ cells in response to RSV infection (94). Thus, it is exciting to speculate that maturation status of CD11 $\mathrm{b}^{+} \mathrm{mDCs}$ may also dictate epitope hierarchy of $\mathrm{CD}^{+}{ }^{+} \mathrm{T}$ cells in response to RSV infection - a concept that we are currently exploring. We further demonstrated that the expression of 
A
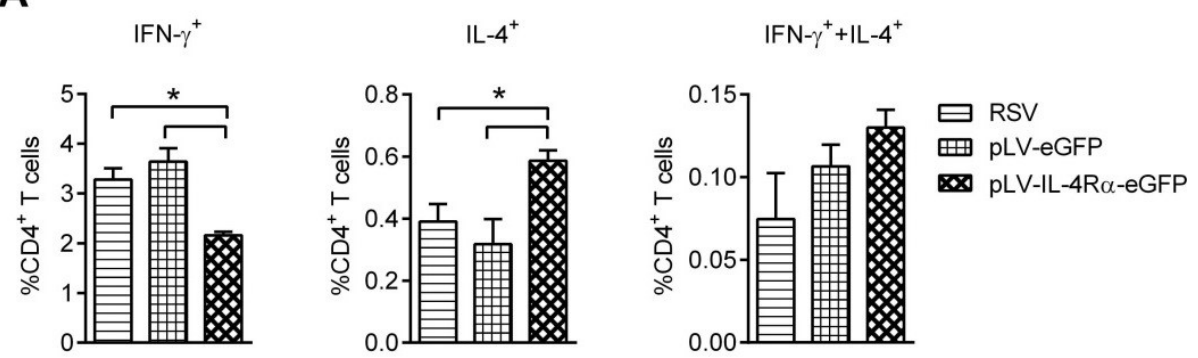

\section{B}
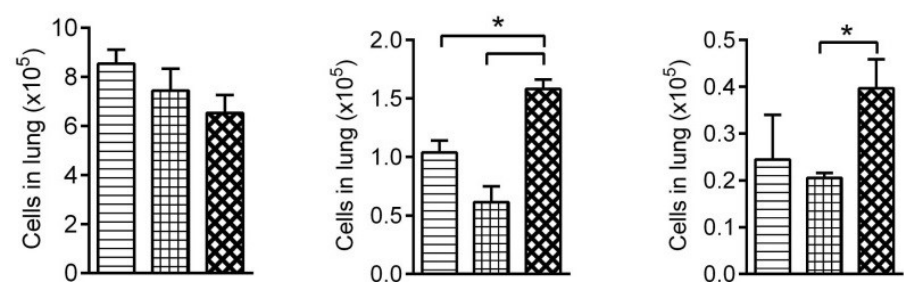

Figure 2-10. Overexpression of IL-4R $\alpha$ on adult $C D 11 b^{+}$mDCs exacerbated $T h 2$ responses to $R S V$ infection in adult mice.

BMDCs were isolated from adult mice, transduced with pLV-IL-4R $\alpha$-eGFP or $\mathrm{pLV-}$ eGFP control, and infected with RSV. CD1 $1 b^{+} \mathrm{mDCs}$ that were positive for eGFP were sorted and adoptively transferred into the lungs of adult mice. These mice were then infected with RSV, and six days later pulmonary Th subsets were quantified. (A) Percentage of CD4 ${ }^{+} T$ cells expressing IFN- $\gamma$, or IL-4, or both IFN- $\gamma$ and IL-4. (B) Number of $\mathrm{CD}^{+} \mathrm{T}$ cells expressing IFN- $\gamma$, or IL-4, or both IFN- $\gamma$ and IL-4. Data are representative of 2 independent experiments with three to four mice per group; ${ }^{*} \mathrm{p}<0.05$. 
$\mathrm{CD} 80$ and $\mathrm{CD} 86$ on $\mathrm{CD} 11 \mathrm{~b}^{+} \mathrm{mDCs}$ was partially regulated by the expression of IL-4R $\alpha$,

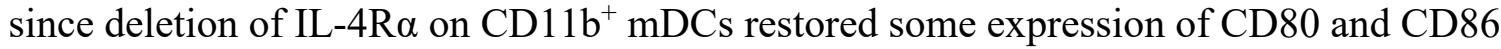
following RSV infection. The mechanism(s) via which IL-4R $\alpha$ is developmentally regulated and how IL-4R $\alpha$ regulates the expression of CD80 and CD86 are currently unclear and warrant further investigation.

The ratio of Th2/Th1 cells decreased by $50 \%$ in the IL-4R $\alpha^{-/-D C}$ mice compared to IL-4R ${ }^{-/ 10 x}$ DC mice both in vivo and in vitro (Figure 2-4\&2-7). While the reduction is not massive, it is significant. The reduction in Th2/Th1 ratio was accompanied by improved lung function and significantly decreased lung pathologies. We have observed this phenomenon in our previous publications $(51,52)$. A subtle reduction in IL-4R $\alpha$ on $\mathrm{Th}$ cells and DCs completely abolished lung dysfunction following RSV reinfection. We think the pathology is determined by the balance of Th1/Th2 immune responses and that a small shift from the Th2 biased immune response is all that is necessary to change the lung pathology.

As with our previous studies $(51,52)$, we observed a $\mathrm{CD} 4^{+} \mathrm{T}$ cell population expressing IFN $-\gamma^{+}$and IL- $4^{+}$following RSV reinfection. Initially, these cells were thought to be pre-Th1/Th2 cells that are in the intermediate stage during the commitment process of Th1/Th2 cells $(95,96)$. However, recent data demonstrate that this phenotype is acquired after full differentiation and that these cells support both type 1 and type 2 inflammatory responses (97). IL-4R $\alpha$ deletion on $\mathrm{CD}_{11} \mathrm{~b}^{+} \mathrm{mDCs}$ decreased the percentage of these cells in the lungs of mice following RSV reinfection. The exact role of these cells in RSV pathogenesis remains elusive, but the reduction of these cells has consistently coincided with reduced pulmonary immunopathophysiology upon RSV reinfection here and in our previously published work $(51,52)$.

Although deletion of IL-4R $\alpha$ on $\mathrm{CD}_{11 \mathrm{~b}^{+}} \mathrm{mDCs}$ did not alter the percentage of pulmonary Th1 $\left(\mathrm{CD}^{+} \mathrm{IFN}^{-} \gamma^{+}\right)$cells following RSV reinfection, there was an increase in the level of IL-12p40 (a Th1 cytokine) in the BALF (Table 2-1). The elevated IL-12p40 level may result from the decreased IL-13, as IL-13 has been previously shown to inhibit IL-12 production via IL-4R $\alpha$ signaling (98).

A limitation of our in vivo studies was that IL-4R $\alpha$ was not specifically deleted on $\mathrm{CD} 11 \mathrm{~b}^{+} \mathrm{mDCs}$. In fact, IL-4R $\alpha$ was deleted on CD11 $\mathrm{c}^{+/ \mathrm{hi}}$ cells including alveolar macrophages (AMs), $\mathrm{CD} 11 \mathrm{~b}^{+} \mathrm{mDCs}$, and $\mathrm{CD}_{103^{+}} \mathrm{mDCs}$; and on $\mathrm{CD} 11 \mathrm{c}^{+/ \mathrm{lo}}$ cells including pDCs, NK cells, B cells, and $\mathrm{CD} 8^{+} \mathrm{T}$ cells (99). However, we believe that our in vitro data ( $\mathrm{T}$ cell activation assays with neonatal $\mathrm{CD} 11 \mathrm{~b}^{+} \mathrm{mDCs}$ ) and in vivo data (adoptive transfer of adult CD11 $\mathrm{b}^{+} \mathrm{mDCs}$ that overexpress IL-4R $\alpha$ ) and data from the literature (summarized below) argue for the specific role of IL-4R $\alpha$ on CD $11 \mathrm{~b}^{+} \mathrm{mDCs}$ in RSV immunopathogenesis. IL-4R $\alpha$ is deleted on $\mathrm{CD}_{103^{+}} \mathrm{mDCs}$ in our model; however, we speculated that the deletion of IL-4R $\alpha$ on $\mathrm{CD}_{103^{+}} \mathrm{mDCs}$ most likely has minimal effect on the Th2-biased response to RSV infection due to the following reasons. $\mathrm{CD}_{103}{ }^{+}$ mDCs mainly activate $\mathrm{CD} 8^{+}$, not $\mathrm{CD} 4^{+}$, $\mathrm{T}$ cells $(67,68)$. Additionally, neonatal $\mathrm{CD} 103^{+}$ mDCs express significantly less IL-4R $\alpha$ compared to their adult counterparts, whereas the Th2-bias is only observed in neonates. In the Cryptococcus infection model, deletion 
of IL-4R $\alpha$ specifically on AMs (LysM ${ }^{\text {Cre }}$ IL-4R $\alpha^{-/ l o x}$ ) was unable to alter the Th2 responses (100), suggesting that IL-4R $\alpha$ expression on AMs has no effect on Th2 polarization. As to the cells expressing low levels of CD11c, we and others (89) have observed inefficient Cre function and thus inefficient deletion of IL-4R $\alpha$ in these cells, including B (89) and T cells (Figure 2-3).

In summary, we have demonstrated a novel age-dependent mechanism (IL-4R $\alpha$ on $\mathrm{CD} 11 \mathrm{~b}^{+} \mathrm{mDCs}$ ) responsible for the Th2-biased immunopathogenesis during neonatal RSV infection. We have shown that IL-4R $\alpha$ expression on CD $11 \mathrm{~b}^{+} \mathrm{mDCs}$ is developmentally regulated, and higher expression of IL-4R $\alpha$ is associated with a less mature phenotype of the $\mathrm{CD}_{11 \mathrm{~b}^{+}} \mathrm{mDCs}$ in response to RSV infection, resulting in Th2biased immune responses. The deletion of IL-4R $\alpha$ on CD11 $\mathrm{b}^{+} \mathrm{mDCs}$ significantly decreased the Th2-biased immunopathogenesis during RSV infection by allowing enhanced maturation of CD $11 \mathrm{~b}^{+} \mathrm{mDCs}$. Our data suggest that modulating IL-4R $\alpha$ signaling on $\mathrm{CD} 1 \mathrm{~b}^{+} \mathrm{mDC}$ may be a strategy for developing RSV therapeutics and that vaccine strategies should investigate such signaling in determining efficacy. 


\section{CHAPTER 3. LIMITED TYPE I IFNS AND PLASMACYTOID DENDRITIC CELLS DURING NEONATAL RESPIRATORY SYNCYTIAL VIRUS INFECTION PERMIT IMMUNOPATHOGENESIS UPON REINFECTION*}

\section{Introduction}

Though it is clear that the adaptive arm of the immune system and its key molecules play vital roles in the immunopathogenesis of RSV disease, adaptive immune responses are first instructed by the innate response. Data generated from human primary cells and adult animal models shed light on the innate immune responses to RSV. In particular, several laboratories have demonstrated that type I IFNs; mainly IFN- $\alpha$ and IFN- $\beta$, and their major producers pDCs are important in protection from RSV disease. It has been reported that RSV stimulates pDCs isolated from human peripheral blood mononuclear cells $(101,102)$ or murine bone marrow-derived pDCs $(103,104)$ to produce type I IFNs ex vivo. Furthermore, several publications have demonstrated that RSV infection of adult mice induces pulmonary type I IFNs in vivo $(75,105)$ and that intranasal administration of recombinant IFN- $\alpha$ significantly reduced lung viral load, inflammation, weight loss, and clinical illness scores of RSV-infected adult mice (106). It has also been demonstrated that RSV infection induces recruitment of pDCs to the lungs of adult mice, and the depletion of pDCs results in increased pulmonary viral load and immunopathology (75).

Despite the apparent roles of type I IFNs and pDCs in determining RSV morbidity, there are few studies investigating pDCs in infants. Data demonstrate that pDCs are recruited to the mucosal compartment of the airways and are readily detectable in nasal washes from children infected with RSV (107); however, there are very low levels of type I IFNs in nasal washes from RSV-infected infants (76). Recent data from Stuart Turvey's group support these findings and demonstrate that pDCs isolated from cord blood of healthy term infants are unable to mount robust type I IFN responses upon RSV infection ex vivo when compared to pDCs from healthy adults, suggesting that human infant $\mathrm{pDCs}$ are immature and/or less responsive at birth (87).

The present study is the first attempt, to our knowledge, to characterize the role of type I IFNs and pDC responses in the immunopathogenesis during RSV reinfection using a neonatal mouse model. Our data demonstrate that neonatal mice mounted limited type I IFNs and pDC responses during primary RSV infection. Treatment of neonatal mice with IFN- $\alpha$ or adoptive transfer of adult pDCs prior to RSV infection significantly reduced Th2-biased immunopathophysiology, strongly suggesting that limited type I IFN and

\footnotetext{
*Adapted with permission. Cormier, SA, Shrestha B, Saravia J, Lee GI, Shen L, DeVincenzo JP, Kim YI, and You D. Limited type I interferons and plasmacytoid immunopathogenesis upon reinfection. 2014. J. Virol. 88: 9350-9360

immunopathophysiology in response to RSV infection.
} 
pDC responses during infancy permit the development of a Th2-biased-dendritic cells during neonatal respiratory syncytial virus infection permit

\section{Materials and Methods}

Mice

BALB/c mice were purchased from Harlan Laboratories (Indianapolis, IN, USA) and maintained in specific-pathogen-free facilities at Louisiana State University Health Sciences Center (LSUHSC, New Orleans, LA, USA) and University of Tennessee Health Science Center (UTHSC, Memphis, TN, USA). Breeders were time-mated and pups born on the same date were used for experiments. A set of pups were allowed to mature to 6-8 weeks of age and were then used as adult controls or the cell source of pDCs for adoptive transfer studies.

All animal protocols were prepared in accordance with the Guide for the Care and Use of Laboratory Animals and approved by the Institutional Animal Care and Use Committee at LSUHSC or UTHSC.

\section{IFN- $\alpha$ Treatment}

Mouse recombinant IFN- $\alpha$ was purchased from PBL Interferon Source (Piscataway, NJ, USA). Sixteen hours prior to RSV infection, $2 \times 10^{3}$ units of IFN- $\alpha$ was instilled intranasally into pups in $10 \mu \mathrm{l}$ of PBS containing $0.1 \%$ BSA. Control pups (NS) received $10 \mu \mathrm{l}$ of PBS containing $0.1 \% \mathrm{BSA}$.

\section{Purification of pDCs or CD11 ${ }^{+}$Cells and Adoptive Transfer}

pDCs were purified from adult spleens using OptiPrep gradient medium (SigmaAldrich, St. Louis, MO, USA) and a negative selection kit from Miltenyi Biotec Inc. (Auburn, CA, USA). Briefly, a single cell suspension of spleens was prepared using gentleMACS ${ }^{\text {TM }}$ Octo Dissociator and the spleen dissociation kit. Spleen cells were then suspended in HBSS containing 15\% OptiPrep and overlaid onto 11.5\% OptiPrep and centrifuged. Low density cells consisting of mostly dendritic cells were collected and subjected to further purification for pDCs using the negative selection kit as per manufacturer's instructions. The purity of the pDCs isolated was verified by flow cytometry and was above $85 \%$. For adoptive transfer studies, pDCs were purified as above and suspended in $10 \mu 1$ serum-free medium (SFM; SFM4MegaVir ${ }^{\text {TM}}$; HyClone, Logan, UT, USA); and $3 \times 10^{4} \mathrm{pDCs}$ were intranasally instilled into pups $16 \mathrm{~h}$ prior to RSV infection. Control pups received $10 \mu \mathrm{SFM}$. 
CD1 $1 \mathrm{c}^{+}$cells were purified from adult spleens for adoptive transfer. Adult splenocytes were isolated as above and CD11 $\mathrm{c}^{+}$cells selected using a positive selection kit from Stemcell Technologies (Vancouver, British Columbia, Canada). The purity of isolation was above $90 \%$. CD11 $\mathrm{c}^{+}$cells were suspended in $10 \mu 1 \mathrm{SFM}$; and $3 \times 10^{4}$ cells were instilled intranasally into pups $16 \mathrm{~h}$ prior to RSV infection. Control pups received $10 \mu \mathrm{l}$ SFM.

\section{Assessment of Pulmonary Viral Load}

At four days post-initial RSV infection, lungs were isolated, weighed, and frozen until analysis by either plaque assay (108) or real time RT-PCR methods (91). For plaque assays, supernatants from centrifuged lung homogenates were added onto Vero cells and overlaid with $0.3 \%$ agarose (MP Biochemicals, Santa Ana, CA, USA). Cells were incubated for three days, fixed with $1 \%$ formaldehyde, and stained with $0.5 \%$ neutral red (Sigma-Aldrich). The plaques were counted and viral load were expressed as plaqueforming units (PFU)/g lung tissue.

For real time PCR, RNA was isolated from frozen lungs using Qiagen (Valencia, CA) RNeasy plus mini kit as per the manufacturer's instructions. Real time RT-PCR was then performed using SuperScript ${ }^{\circledR}$ III Platinum ${ }^{\circledR}$ One-Step qRT-PCR Kit from Life Technologies (Carlsbad, CA, USA). The primers (91) used for the reaction were:

NS1, forward primer: 5'-CACAACAATGCCAGTGCTACAA-3'

NS1, reverse primer: 5'-TTAGACCATTAGGTTGAGAGCAATGT-3'

\section{Cell Staining and Flow Cytometry}

To measure pDC levels in the lung, single cells were isolated and labeled with fixable viability dye and antibodies to CD11c (N418) and PDCA-1 (eBio129c). Stained cells were then assayed on a Canto II flow cytometer (BD Biosciences, Franklin Lakes, NJ, USA), and flow data were analyzed and plotted with FlowJo software (version 7.6.5 for Windows; Tree Star; Ashland, OR, USA). Singlet live cells were gated before any further analysis. All buffers, viability dyes, and antibodies were purchased from eBiosciences unless otherwise stated.

To determine the $\mathrm{CD}^{+} \mathrm{T}$ cell populations in the lung, single cells were isolated as above and stimulated for $5 \mathrm{~h}$ in RPMI-1640 (HyClone) containing 10\% heat inactivated fetal bovine serum (FBS; Life Technologies), $100 \mathrm{U} / \mathrm{ml}$ penicillin (HyClone), $100 \mathrm{mg} / \mathrm{ml}$ streptomycin (HyClone), $5 \mathrm{ng} / \mathrm{ml}$ phorbol-12-myristate-13-acetate (PMA; SigmaAldrich), and $500 \mathrm{ng} / \mathrm{ml}$ ionomycin (Sigma-Aldrich) in the presence of a protein transport inhibitor $\left(1 \mu 1 / 10^{6}\right.$ cells; GolgiPlug, BD Biosciences, Franklin Lakes, NJ). After stimulation, the cells were stained with fixable viability dye, fixed and permeabilized, and labeled with antibodies to CD3 (17A2), CD4 (RM4-4; Biolegend), IFN- $\gamma$ (XMG1.2), and IL-4 (BVD6-24G2). Flow data were then acquired, analyzed, and plotted as above. 


\section{Cytokine Measurement}

Real-time PCR was performed to measure the kinetics of IFN- $\alpha$ expression in the lung. Total lung RNA was isolated using Quick-RNA MiniPrep from Zymo Research (Irvine, CA, USA) and then real time RT-PCR was performed using SuperScript ${ }^{\circledR}$ III Platinum ${ }^{\circledR}$ One-Step qRT-PCR Kit (Life Technologies). The primers used for the reaction were:

IFN- $\alpha$, forward primer: 5'-TGATGAGCTACTACTGGTCAGC-3'

IFN- $\alpha 4$, reverse primer: 5'-GATCTCTTAGCACAAGGATGGC-3'

To measure protein levels of type I IFNs in the lung, total lung proteins were isolated using T-PER Tissue Protein Extraction Reagent and quantified using BCA Protein Assay Reagent (Thermo Fisher Scientific). Levels of IFN- $\alpha$ and IFN- $\beta$ were then measured using ELISA kits as per the manufacturer's instruction (PBL Interferon Source). The limit of detection was $12.5 \mathrm{pg} / \mathrm{ml}$ for IFN- $\alpha$ and $15.6 \mathrm{pg} / \mathrm{ml}$ for IFN- $\beta$. All data presented are above the limit of detection.

The level of other cytokines in the BALF including IFN- $\gamma$, IL-12 (p40), IL-4, and IL-13 were measured using Milliplex mouse cytokine/chemokine assay kit (Millipore Corporation; Billerica, MA, USA) on the Bio-plex system (Bio-Rad Laboratories; Hercules, CA, USA). Data outside of the sensitivity level of detection were excluded.

\section{Statistics}

Data were plotted as means \pm standard errors (SEM) and analyzed using Prism 6 (GraphPad Software; La Jolla, CA, USA). Student's $t$-test was used for all mouse studies except for the pulmonary function test, which was analyzed by two-way analysis of variance (ANOVA) and Bonferroni posthoc tests. Each figure represents one experiment. In the legend, $\mathrm{n}$ represents the number of animals and every experiment was repeated at least twice. Differences were considered significant if $p<0.05$.

\section{Results}

\section{RSV Infection Induced Limited Type I IFNs and pDC Responses in Neonatal Mouse Lungs}

Type I IFNs are important anti-viral cytokines induced during viral infections. We measured the amount of type I IFNs in the lung at various time points post-RSV infection. Neonates were infected with RSV and lungs were isolated at $5 \mathrm{~h}, 1 \mathrm{~d}, 2 \mathrm{~d}, 4 \mathrm{~d}$ and $6 \mathrm{~d}$ post-infection (dpi). The expression of IFN- $\alpha$ was measured at these time points 
using real-time RT-PCR. Although it has been reported that RSV A2 and clinical strains are capable of inhibiting type I IFNs expression in human cells ex vivo (109), we observed induction of IFN- $\alpha$ in the lungs of RSV-infected mice as early as $5 \mathrm{~h}$ postinfection and a peak in IFN- $\alpha$ at 1 and 2 dpi (Figure 3-1A). We further measured protein levels of type I IFNs, including both IFN- $\alpha$ and IFN- $\beta$, in the lung homogenates of RSVinfected neonatal vs. adult mice. IFN- $\beta$ was slightly, but significantly, increased at $1 \mathrm{dpi}$ in neonates (Figure 3-1C); neonate RSV vs. neonate Sham: $11.84 \pm 1.22$ vs. $5.57 \pm 0.57$ $\mathrm{ng} / \mathrm{g}$ lung protein); whereas IFN- $\alpha$ was not significantly different from sham-infected neonates (Figure 3-1B); neonate RSV vs. neonate Sham: $5.51 \pm 0.51$ vs. $4.35 \pm 0.39 \mathrm{ng} / \mathrm{g}$ lung protein). More importantly, adults infected with RSV induced significantly greater amounts of IFN- $\alpha$ (Figure 3-1B); adult RSV vs. adult Sham: $76.16 \pm 5.59$ vs. $3.77 \pm 0.45$ ng/g lung protein) and IFN- $\beta$ (Figure 3-1B); adult RSV vs. adult Sham: $42.25 \pm 2.92$ vs. $8.14 \pm 1.15 \mathrm{ng} / \mathrm{g}$ lung protein) compared to sham-infected adults at $1 \mathrm{dpi}$. Both IFN- $\alpha$ and IFN- $\beta$ from RSV-infected adults were significantly higher than in RSV-infected neonates.

Numerous reports have shown that pDCs are a major source of type I IFNs during viral infections $(110,111)$; we, therefore, compared the kinetics of pDCs during RSV infection in neonatal vs. adult mice. Neonates or adults were infected with RSV and the number of pDCs in the lung was measured at $5 \mathrm{~h}, 7 \mathrm{~d}, 14 \mathrm{~d}$, and $21 \mathrm{dpi}$ using flow cytometry (Figure 3-2). RSV infection induced recruitment of pDCs to the lung, with levels peaking at $7 \mathrm{dpi}$ and declining to baseline levels by $21 \mathrm{dpi}$ in both adults and neonates (Figure 3-2A\&B). The frequency of pDCs was substantially greater at 7 dpi in RSV-infected adults compared to sham-infected adults (Figure 3-2D; $6.16 \pm 0.68$ vs. $0.33 \pm 0.06 \%$ ); whereas there was only a slight, but significant, increase in the frequency of pDCs from RSV-infected neonates compared to sham-infected neonates (Figure 3-2C; $0.38 \pm 0.05$ vs. $0.26 \pm 0.01 \%)$. Additionally, the frequency of pDCs was significantly greater at 7 dpi in adults infected with RSV $(6.16 \pm 0.68 \%)$ compared to neonates infected with RSV $(0.38 \pm 0.05 \%)$ (Figure 3-2A). These results indicated that RSV infection in neonates induced limited type I IFNs and pDC responses in the lung.

\section{IFN-a Treatment Prior to Neonatal RSV Infection Mitigated Airway Hyperreactivity and Lung Pathology during Reinfection}

Both our laboratory and other groups have shown that mice initially infected as neonates, compared to mice initially infected as adults, exhibit exacerbated airway hyperreactivity (AHR) and lung pathology during RSV reinfection (52-54); we therefore monitored lung function and pathology following reinfection in mice that were treated with IFN- $\alpha$ prior to neonatal RSV infection. Four-day-old pups were treated intranasally with $2 \times 10^{3} \mathrm{U}$ [dose extrapolated from dosage used in adult mice (75)] of IFN- $\alpha$ or vehicle and then infected with RSV or serum-free media at $16 \mathrm{~h}$ post-treatment. These mice were then reinfected with RSV at 4 wks post-primary infection and AHR and lung pathology were assessed at $6 \mathrm{~d}$ post-reinfection (Figure 3-3). Pulmonary viral load data from other groups have shown that RSV infects and replicates in the lung following reinfection (53). 
A

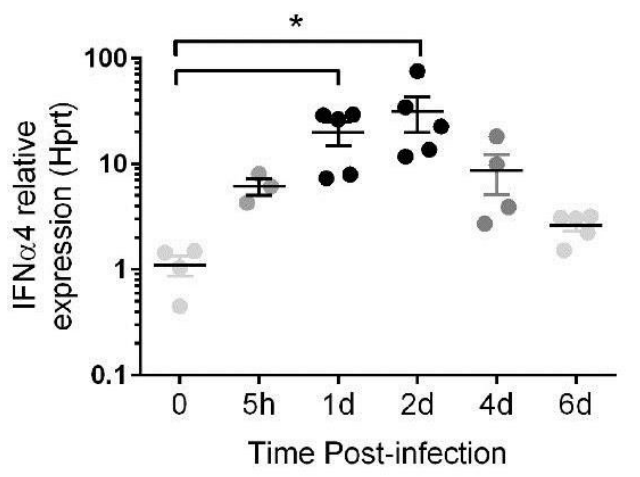

B

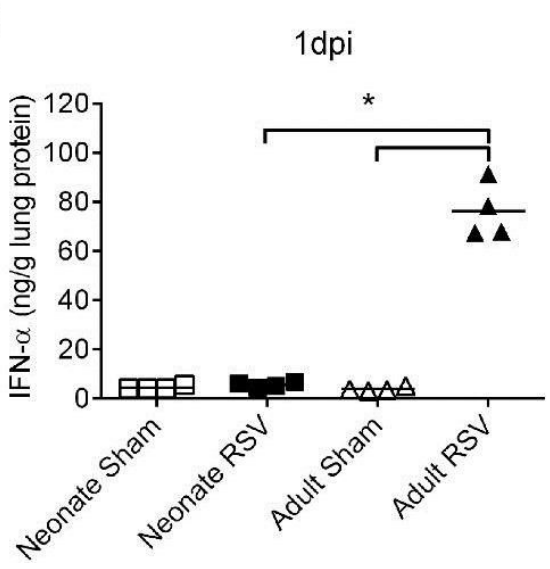

C

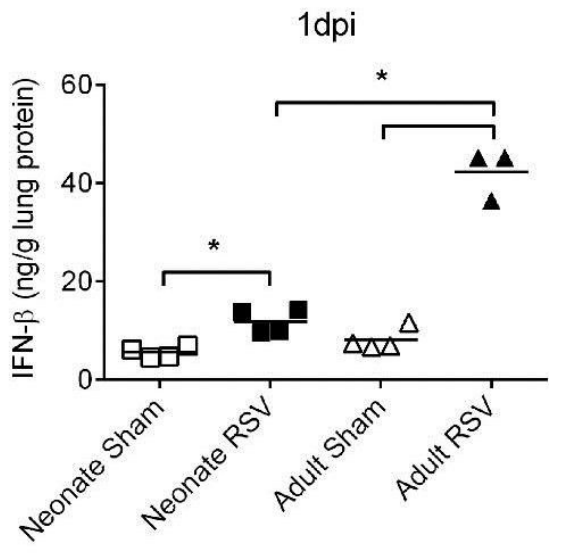

Figure 3-1. RSV infection induced limited type I IFNs in neonatal mouse lungs. Five-day-old neonates were infected with RSV and the expression of IFN-a4 was measured at various time points post-infection via real-time $\mathrm{RT}-\mathrm{PCR}$. $\mathrm{N}=3-5$ mice. To compare the protein levels of type I IFNs, neonates or adults were infected with RSV or media and the concentrations of IFN- $\alpha$ and IFN- $\beta$ at 1 dpi were measured in lung homogenates using ELISA. (A) Kinetics of IFN- $\alpha$ in neonates. (B) IFN- $\alpha$ production in neonates and adults. (C) IFN- $\beta$ production in neonates and adults. $\mathrm{N}=3-4$ mice.

Individual data are shown with mean $\pm \mathrm{SEM}, * p<0.05$. (This experiment was performed by Dahui) 
A
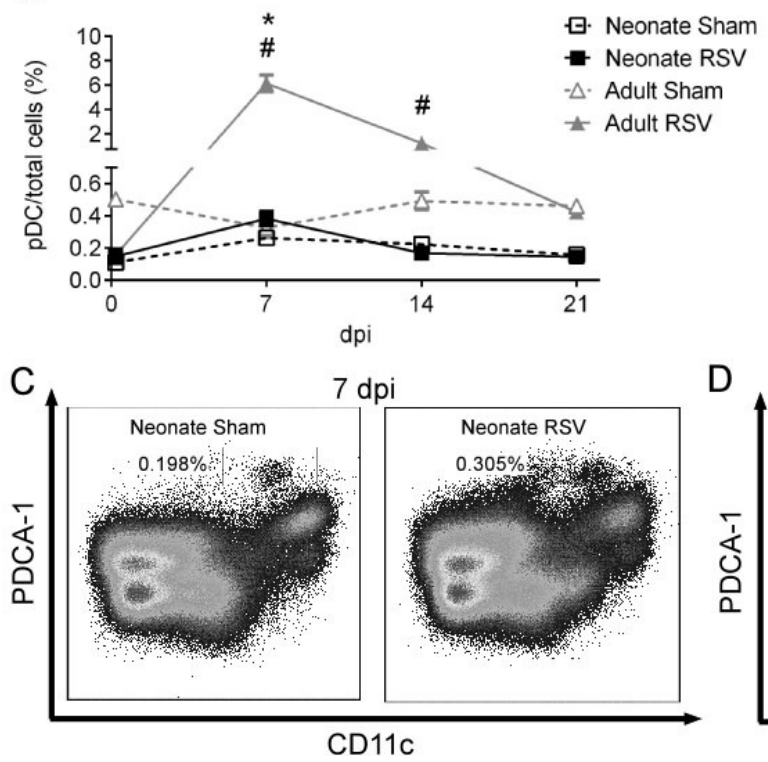

B
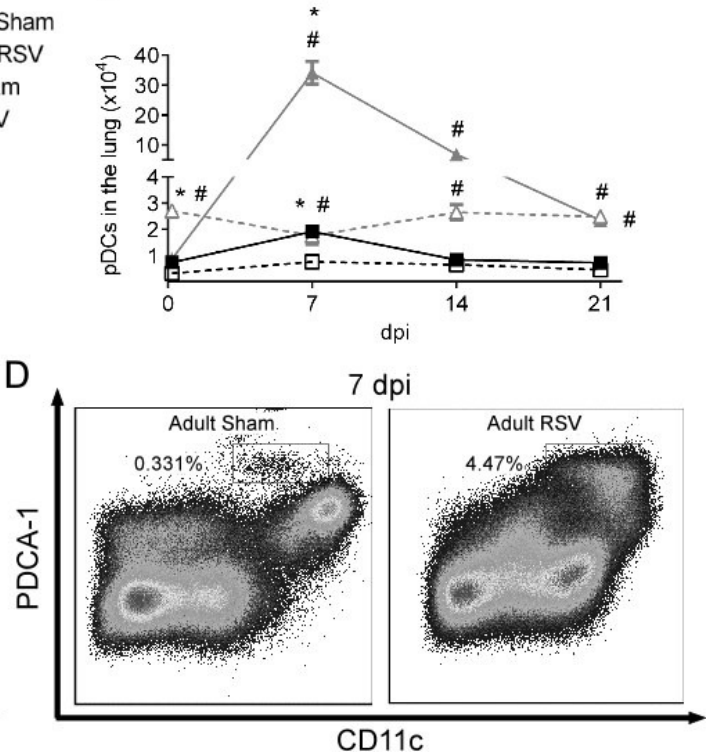

Figure 3-2. RSV infection induced limited recruitment of pDCs to neonatal lungs. Five-day-old pups or adults were infected with RSV or sham and the numbers of pDCs in the lungs were measured using flow cytometry at various time points. (A) Kinetics of pulmonary pDCs expressed as percentages of total lung cells. (B) Kinetics of pDCs expressed as total numbers in lungs. (C) Representative flow plots for $\mathrm{pDCs}$ $\left(\mathrm{CD} 11 \mathrm{c}^{+} \mathrm{PDCA}-1^{+}\right)$in neonates at 7 dpi. (D) Representative flow plots for $\mathrm{pDCs}$ in adults at 7 dpi. $\mathrm{N}=4$ mice, ${ }^{*} \mathrm{p}<0.05$ (RSV vs. sham), $\# \mathrm{p}<0.05$ (adult vs. neonate). Data are presented as mean $\pm \mathrm{SEM}$. 
A

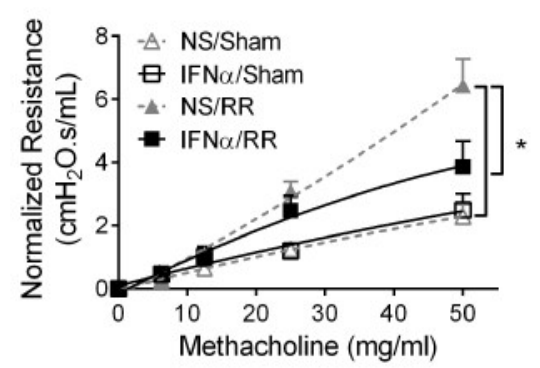

C

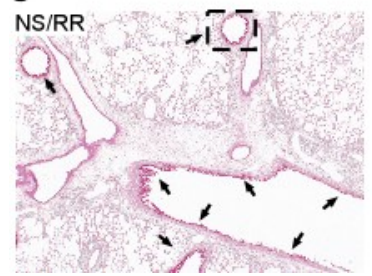

$B$
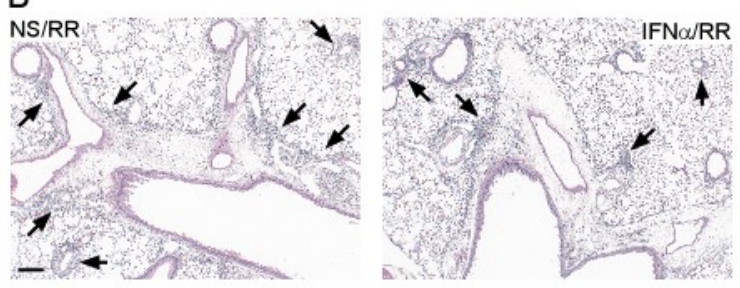

D

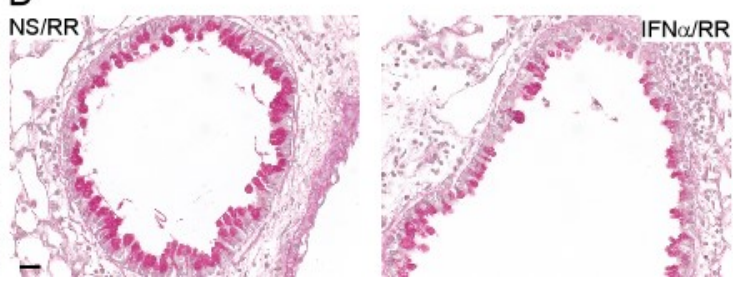

Figure 3-3. IFN- $\alpha$ treatment prior to neonatal RSV infection attenuated AHR, inflammation, and mucus hyperproduction during RSV reinfection.

Four-day-old pups were treated with IFN- $\alpha$ or vehicle. These mice were infected $16 \mathrm{~h}$ later, allowed to mature to adults, and reinfected with RSV at 4 weeks post-initial infection. Airway hyperactivity and lung pathology was assessed at six days postreinfection. (A) Airway resistance to methacholine. $\mathrm{N}=5-6$ mice, ${ }^{*} p<0.05$.(B) Lung slides stained with H\&E. Arrows indicate inflammatory cells. 100 x magnification. Scale bar $=200 \mu \mathrm{m}$. (C) Lung slides stained with PAS. Magenta staining indicates mucus. Arrows point to mucus-positive regions. 100x magnification. (D) Enlarged images of selected regions in C. 400x magnification. Scale bar $=50 \mu \mathrm{m}$. NS/sham: mice treated with vehicle and mock-infected; IFN- $\alpha$ /sham: mice treated with IFN- $\alpha$ and mockinfected; NS/RR: mice treated with vehicle, infected as neonates, and reinfected with RSV as adults; IFN- $\alpha /$ RR: mice treated with IFN- $\alpha$, infected as neonates, and reinfected with RSV as adults. Data are presented as mean \pm SEM. (This experiment was performed by Dr. Dahui You in assistance with Dr. Jordy Saravia) 
Expectedly, the airway resistance to methacholine in mice initially infected as neonates (NS/RR) was significantly higher compared to sham-infected mice (NS/Sham; $6.44 \pm 0.83$ vs. $2.29 \pm 0.38 \mathrm{cmH}_{2} \mathrm{O} . \mathrm{s} / \mathrm{mL}$ ) (Figure 3-3A). IFN- $\alpha$ treatment prior to neonatal RSV infection substantially decreased AHR (IFN- $\alpha$ /RR vs. NS/RR: $3.86 \pm 0.81$ vs. $6.44 \pm 0.83 \mathrm{cmH}_{2} \mathrm{O} . \mathrm{s} / \mathrm{mL}$ ), while there was no significant difference in AHR between mice treated with IFN- $\alpha$ prior to RSV infection with mice treated with vehicle prior to sham infection (IFN- $\alpha /$ RR vs. NS/Sham: $3.86 \pm 0.81$ vs. $2.29 \pm 0.38 \mathrm{cmH}_{2} \mathrm{O} . \mathrm{s} / \mathrm{mL}$ ). No difference was observed in airway resistance between sham-infected mice treated with IFN- $\alpha$ and vehicle (NS/Sham vs. IFN- $\alpha /$ Sham: $2.50 \pm 0.51$ vs. $2.29 \pm 0.38 \mathrm{cmH}_{2} \mathrm{O} . \mathrm{s} / \mathrm{mL}$ ).

Consistent with the lung function data, lung pathology demonstrated that RSV reinfection induced moderate peribronchial and perivascular inflammation in the lung, which was reduced with IFN- $\alpha$ treatment prior to RSV infection (Figure 3-3B). In particular, a striking decrease in eosinophils was observed around the airways of mice treated with IFN- $\alpha$ compared to control mice (IFN- $\alpha /$ RR vs. NS/RR: $1,095 \pm 185$ vs. $66 \pm$ 31 eosinophils/surface area of lung parenchyma). In addition, significantly fewer mucusproducing cells, indicated by positive PAS staining, were detected in the lungs of mice treated with IFN- $\alpha$ compared to control mice (Figure 3-3C\&D); IFN- $\alpha /$ RR vs. NS/RR $0.40 \pm 0.02$ vs. $0.26 \pm 0.03$ mucus + cells/surface area of airway;). Little to no inflammation or mucus production was observed in mice treated with IFN- $\alpha$ or vehicle and sham-infected (data not shown).

These data demonstrated a prophylactic effect of IFN- $\alpha$ on RSV infection in neonates that included significantly reduced AHR, pulmonary inflammation, and mucus hyperproduction during RSV reinfection.

\section{IFN- $\alpha$ Treatment Prior to Neonatal RSV Infection Mitigated Th2-biased Responses during Reinfection}

Cellular immunological analysis has previously revealed that the AHR and lung pathology in mice initially infected as neonates are associated with biased pulmonary Th2 responses (52). We therefore measured various parameters of the Th cell immune response in the lung, including pulmonary Th cell subsets, cellularity of bronchoalveolar lavage fluid (BALF), and cytokine levels in BALF (Figure 3-4).

Mice were treated and infected as above and lung cells were isolated at $6 \mathrm{~d}$ postreinfection and stained for surface markers, $\mathrm{CD} 3$ and $\mathrm{CD} 4$, and intracellular cytokines, IFN- $\gamma$ and IL-4. We have previously shown that mice initially infected as neonates induce considerably more Th2 cells in the lung during reinfection compared to mice initially infected as adults, while the level of Th1 cells in the lung remain similar (hence Th2biased) (52).

Here, we confirmed that RSV reinfection of mice initially infected as neonates (NS/RR) induced high levels of Th1 cells $\left(\mathrm{CD}^{+}{ }^{+} \mathrm{CD} 4^{+} \mathrm{IFN}-\gamma^{+} \mathrm{IL}-4^{-}\right)$and moderate levels 

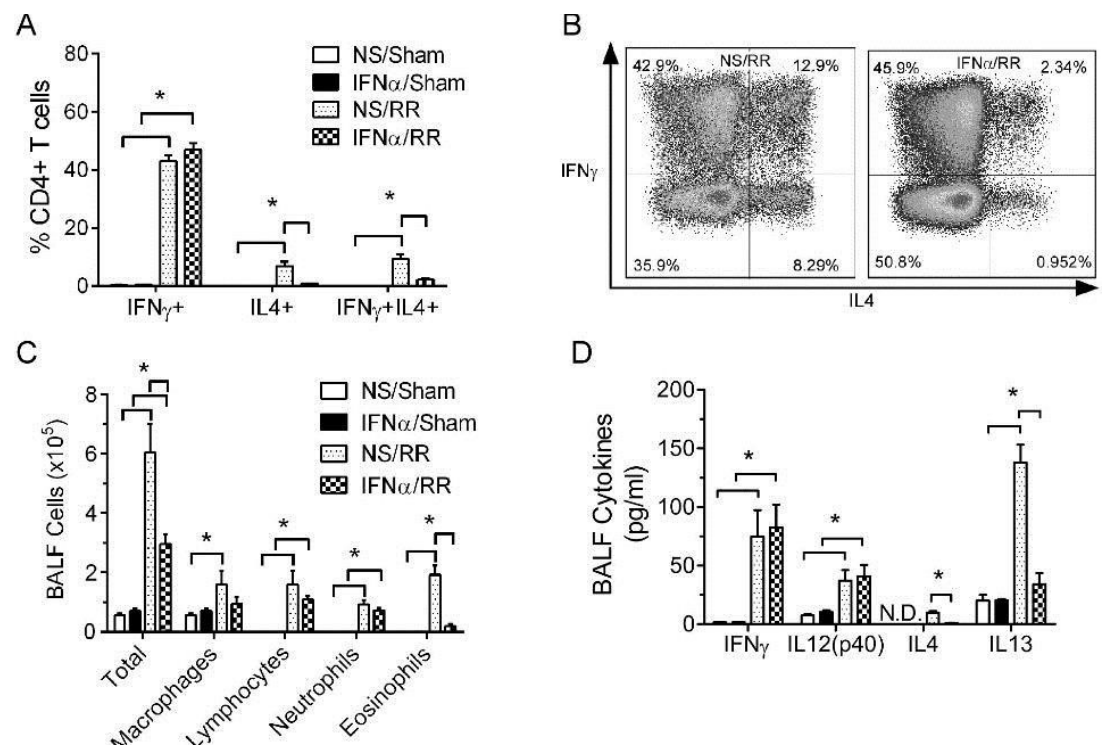

Figure 3-4. IFN- $\quad$ treatment prior to neonatal RSV infection mitigated the Th2biased responses during reinfection.

Four-day-old pups were treated with IFN- $\alpha$ or vehicle. These mice were infected $16 \mathrm{~h}$ later, allowed to mature to adults, and reinfected with RSV at 4 wks post-initial infection. Pulmonary $\mathrm{T}$ helper cell profiles and BALF cellularity and cytokine levels were measured at 6 dpi. (A) Pulmonary Th profile. $\mathrm{N}=4-5$ mice. ${ }^{*} p<0.05$. (B)

Representative flow plot of Th cells from mice treated with IFN- $\alpha$ or vehicle and infected with RSV. (C) BALF cellularity. $\mathrm{N}=5-6 .{ }^{*} p<0.05$. (D) BALF cytokine levels. $\mathrm{N}=3-5$ mice. ${ }^{*} p<0.05$. NS/sham: mice treated with vehicle and mock-infected; IFN- $\alpha /$ sham: mice treated with IFN- $\alpha$ and mock-infected; NS/RR: mice treated with vehicle, infected as neonates, and reinfected with RSV as adults; IFN- $\alpha /$ RR: mice treated with IFN- $\alpha$, infected as neonates, and reinfected with RSV as adults. Data are presented as mean \pm SEM. 
of Th2 cells $\left(\mathrm{CD}^{+} \mathrm{CD} 4^{+} \mathrm{IFN}-\gamma^{-} \mathrm{IL}-4^{+}\right)$and multifunctional Th cells $\left(\mathrm{CD} 3^{+} \mathrm{CD} 4^{+} \mathrm{IFN}-\gamma^{+} \mathrm{IL}-\right.$ $4^{+}$) in the lung (Figure 3-4A). IFN- $\alpha$ treatment prior to neonatal RSV infection substantially reduced the level of Th2 cells (IFN- $\alpha /$ RR vs. NS/RR: $0.84 \pm 0.16$ vs. $6.80 \pm$ $1.66 \%)$ and multifunctional cells $(2.15 \pm 0.42$ vs. $9.39 \pm 1.67 \%)$ while maintaining the level of Th1 cells (46.96 \pm 2.14 vs. $42.94 \pm 2.04 \%$; Figure 3-4A-B).

As in our previous publications $(51,52), \mathrm{RSV}$ reinfection increased inflammatory cells in the BALF, including alveolar macrophages, lymphocytes, neutrophils, and eosinophils (Figure 3-4C). Consistent with reduced pulmonary inflammation (Figure 34B), IFN- $\alpha$ treatment prior to neonatal RSV infection significantly decreased total inflammatory cells in the BALF during reinfection compared to mice treated with vehicle (IFN- $\alpha /$ RR vs. NS/RR: $2.96 \pm 0.34$ vs. $6.04 \pm 0.96 \times 10^{5}$ cells $\left./ \mathrm{mL}\right)$. This decrease in total inflammatory cells was mainly due to the decrease in eosinophils $(0.20 \pm 0.07$ vs. $1.92 \pm$ $0.32 \times 10^{5}$ cells $/ \mathrm{mL}$ ).

In line with the BALF cellularity and pulmonary Th profile, IFN- $\alpha$ treatment prior to neonatal RSV infection significantly reduced Th2 cytokines in BALF during reinfection, including both IL-4 and IL-13 (Figure 3-4D; IFN- $\alpha$ /RR vs. NS/RR: $0.98 \pm$ 0.12 vs. $9.88 \pm 1.42$ and $34.10 \pm 9.47$ vs. $137.93 \pm 15.1 \mathrm{pg} / \mathrm{mL})$. No difference in Th1 cytokines was observed between IFN- $\alpha$ - and vehicle-treated mice, including both IFN- $\gamma$ and IL-12 (82.79 \pm 19.31 vs. $74.70 \pm 22.76$ and $40.98 \pm 9.53$ vs. $37.00 \pm 9.12 \mathrm{pg} / \mathrm{mL})$. Collectively, the pulmonary Th profile, BALF cellularity and cytokine levels shown above demonstrated that IFN- $\alpha$ treatment prior to neonatal RSV infection decreased Th2biased responses and reduced RSV pathogenesis upon reinfection.

\section{Adoptive Transfer of Purified Adult pDCs Prior to Neonatal RSV Infection Induced Pulmonary IFN- $\alpha$ Expression and Alleviated RSV Reinfection-Associated Immunopathophysiology}

As demonstrated above, RSV infection induced limited pDC and type I IFN responses in the neonatal lung. Additionally, IFN- $\alpha$ treatment prior to neonatal RSV infection reduced the typical Th2 immunopathophysiology during reinfection. Because pDCs are the major source of type I IFNs (111), we hypothesized that adoptive transfer adult pDCs prior to neonatal RSV infection would also reduce the Th2 immunopathophysiology during reinfection. Four-day-old pups received $3 \times 10^{4}$ adult pDCs instilled intranasally. The number of pDCs instilled was roughly the number of pulmonary pDCs observed in adult naïve mice. Because it is extraordinarily difficult to isolate this number of pDCs from neonates, control pups received vehicle (serum-free medium; SFM). Pups were infected with RSV at $16 \mathrm{~h}$ post-adoptive transfer and reinfected at 4 weeks post-initial infection. Various endpoints were measured at $6 \mathrm{~d}$ postreinfection, including AHR, BALF cellularity, and pulmonary Th profile (Figure 3-5). A set of pups was used to measure the IFN- $\alpha$ expression in the lung at $1 \mathrm{dpi}$.

Because pDCs are the major source of type I IFNs during viral infections, we measured the expression of IFN- $\alpha$ in lung homogenates at $1 \mathrm{dpi}$ in pups receiving adult 
A

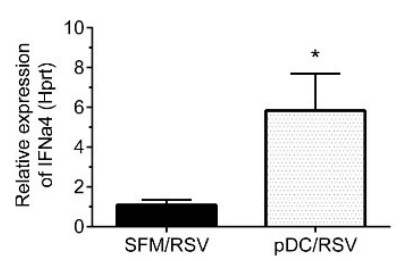

C

E
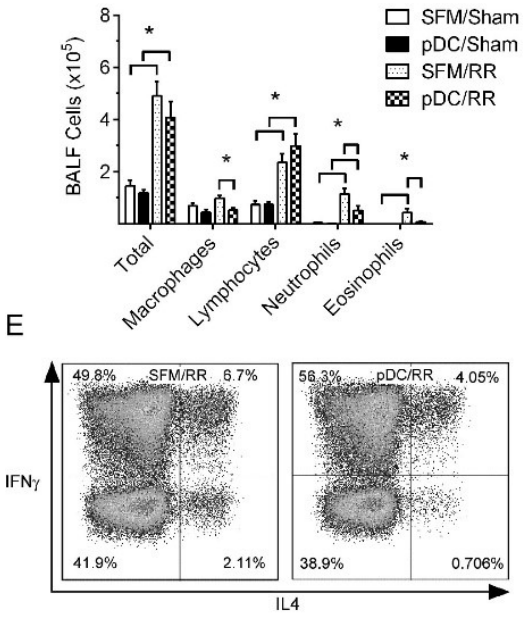

B
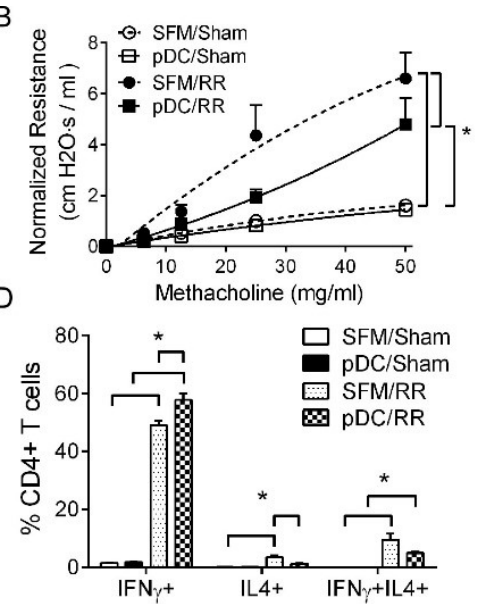

$\mathrm{F}$

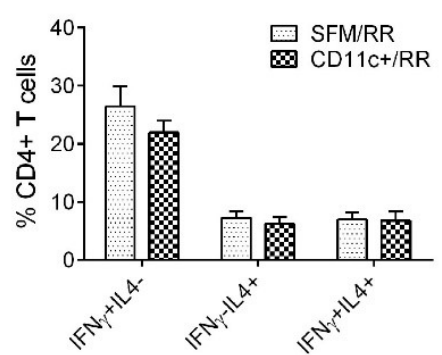

Figure 3-5. Adoptive transfer of adult pDCs prior to neonatal RSV infection induced pulmonary IFN- $\alpha$ expression and attenuated the Th2-biased immunopathologies during RSV reinfection.

Four-day-old pups received adult pDCs (A-E) or CD11 ${ }^{+}$cells (F) or serum-free medium (SFM, A-F) $16 \mathrm{~h}$ before initial RSV infection. After four weeks, these mice were reinfected with RSV, and airway resistance, BALF cellularity, and Th cell profiles were measured at six days post-reinfection. (A) Relative IFN $\alpha$ expression in the lung homogenates at 1 dpi. $\mathrm{N}=5$ mice. ${ }^{*} p<0.05$. (B) Airway resistance to methacholine. $\mathrm{N}=$ 4-5 mice, ${ }^{*} p<0.05$. (C) BALF cellularity. $\mathrm{N}=4-5,{ }^{*} p<0.05$. (D) Pulmonary Th profile. $\mathrm{N}=4-6$ mice, $* p<0.05$. (E) Representative flow plot of D. (F) Pulmonary Th profile in mice receiving $\mathrm{CD} 11 \mathrm{c}^{+}$cells or SFM. $\mathrm{N}=5$ mice, ${ }^{*} p<0.05$. SFM/RSV: pups receiving SFM and infected with RSV; pDC/RSV: pups receiving adult pDCs and infected with RSV; SFM/sham: mice receiving SFM and mock-infected; $\mathrm{pDC} /$ sham: mice receiving pDCs and mock-infected; SFM/RR: mice receiving SFM, infected as neonates, and reinfected with RSV as adults; $\mathrm{pDC} / \mathrm{RR}$ : mice receiving $\mathrm{pDCs}$, infected as neonates, and reinfected with RSV as adults. CD11 $\mathrm{c}^{+} / \mathrm{RR}$ : mice receiving $\mathrm{CD} 11 \mathrm{c}^{+}$cells, infected as neonates, and reinfected with RSV as adults. Data are presented as mean $\pm \mathrm{SEM}$.

(Dr. Dahui You performed parts of these experiments.) 
pDCs or vehicle. As shown in (Figure 3-5A), pups receiving adult pDCs exhibited a sixfold induction of IFN- $\alpha$ in the lungs compared to the mice receiving vehicle.

RSV reinfection induced AHR in mice initially infected as neonates compared to sham-infected mice (Figure 3-5B; SFM/RR vs. SFM/Sham: $6.60 \pm 1.01$ vs. $1.62 \pm 0.15$ $\mathrm{cmH}_{2} \mathrm{O} . \mathrm{s} / \mathrm{mL}$ ). Adoptive transfer of adult $\mathrm{pDCs}$ to the lung prior to neonatal RSV infection significantly reduced AHR compared to control mice ( $\mathrm{pDC} / \mathrm{RR}$ vs. SFM/RR: $4.80 \pm 1.03$ vs. $6.60 \pm 1.01 \mathrm{cmH}_{2} \mathrm{O} . \mathrm{s} / \mathrm{mL}$ ); and the airway resistance in mice receiving adult $\mathrm{pDCs}$ was no different than mice receiving vehicle and sham-infected (pDC/Sham vs. SFM/Sham: $1.45 \pm 0.14$ vs. $\left.1.62 \pm 0.15 \mathrm{cmH}_{2} \mathrm{O} . \mathrm{s} / \mathrm{mL}\right)$.

Analysis of BALF cellularity demonstrated significant reductions in the number of alveolar macrophages $\left(0.56 \pm 0.09\right.$ vs. $0.97 \pm 0.09 \times 10^{5}$ cells $\left./ \mathrm{mL}\right)$, neutrophils $(0.51 \pm$ 0.18 vs. $1.14 \pm 0.22$ cells $/ \mathrm{mL})$, and particularly eosinophils $(0.07 \pm 0.03$ vs. $0.43 \pm 0.16$ cells $/ \mathrm{mL}$ ) during reinfection in the airways of mice receiving adult $\mathrm{pDCs}$ and infected with RSV as neonates (pDC/RR) compared to control mice receiving vehicle (SFM/RR) (Figure 3-5C). The total inflammatory cells and lymphocytes remained comparable between $\mathrm{pDC} / \mathrm{RR}$ and $\mathrm{SFM} / \mathrm{RR}$ mice. In addition, mice receiving adult $\mathrm{pDCs}$ prior to neonatal RSV infection (pDC/RR) recruited fewer Th2 (1.31 \pm 0.22 vs. $3.50 \pm 0.69 \%)$ and multifunctional Th cells $(5.05 \pm 0.33$ vs. $9.54 \pm 2.13 \%)$ and more Th1 cells $(57.78 \pm$ 2.11 vs. $49.02 \pm 1.59 \%$ ) compared to mice receiving vehicle (SFM/RR; Figure 3-5 D\&E).

In order to exclude the possibility that the effects we observed were due to the adoptive transfer of any type of cells into the neonatal lung, the above experiment was repeated with $3 \times 10^{4} \mathrm{CD} 11 \mathrm{c}^{+}$cells purified from adult spleens and the Th cell profile during reinfection was analyzed. As shown in (Figure 3-5F), no difference was observed in any Th cell subset between the mice receiving vehicle or CD11 $\mathrm{c}^{+}$cells.

Collectively, these data showed that adoptive transfer of purified pDCs into the lungs prior to neonatal RSV infection decreased AHR, airway inflammation and eosinophilia, and pulmonary Th2-biased immune responses during RSV reinfection.

\section{IFN- $\alpha$ Treatment or Adoptive Transfer of pDCs Prior to Neonatal RSV Infection Reduced Pulmonary Viral Load during Primary Infection}

Both IFN- $\alpha$ treatment and adoptive transfer of adult $\mathrm{pDCs}$ prior to neonatal RSV infection decreased Th2-associated immunohistopathology during reinfection. Because IFN- $\alpha$ is an important anti-viral cytokine and is produced mainly by pDCs (111), we hypothesized that IFN- $\alpha$ treatment or adoptive transfer of pDCs prior to RSV infection reduces pulmonary viral load. Four-day-old pups were intranasally instilled with $2 \times 10^{3}$ $\mathrm{U}$ of IFN- $\alpha$ or $3 \times 10^{4} \mathrm{pDCs}$ or vehicle. Sixteen hours after instillation, these mice were infected with RSV and lungs were isolated at 4 dpi for virus quantification using both plaque assays and real-time RT-PCR (Figure 3-6). 

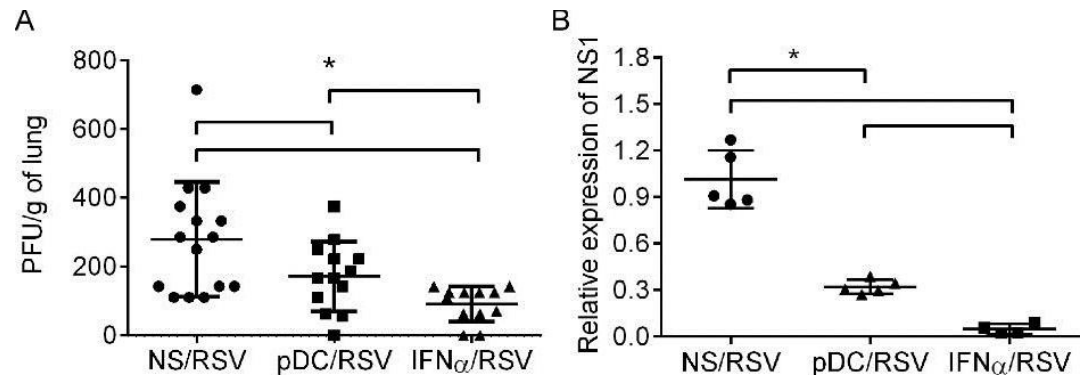

Figure 3-6. IFN- $\alpha$ treatment or adoptive transfer of pDCs decreased pulmonary viral load during primary RSV infection.

Four-day-old pups were treated with IFN- $\alpha$ or vehicle or received pDCs at $16 \mathrm{~h}$ prior to RSV infection. At 4 dpi, lungs were isolated and viral loads were measured in lung homogenates by plaque assay or real time RT-PCR. (A) Plaque assay. $\mathrm{N}=12-15$ mice, $* p<0.05$. (B) Relative expression of NS1. Ct values were normalized to Hprt (housekeeping gene) and then compared to NS/RSV mice. $\mathrm{N}=4-5$ mice, ${ }^{*} p<0.05$. NS/RSV: mice treated with vehicle and infected with RSV; IFN- $\alpha / \mathrm{RSV}$ : mice treated with IFN- $\alpha$ and infected with RSV; $\mathrm{pDC} / \mathrm{RSV}$ : mice receiving $\mathrm{pDCs}$ and infected with RSV.

Individual data are shown with mean \pm SEM. (Dr. Dahui You performed this experiment) 
Plaque assays demonstrated that IFN- $\alpha$ treatment considerably reduced live RSV titer from $280 \pm 43$ to $91 \pm 15 \mathrm{PFU} / \mathrm{g}$ of lung (Figure 3-6A). Consistent with the plaque assay data, real-time RT-PCR data demonstrated a 96\% reduction in relative expression of the NS1 gene in mice pre-treated with IFN- $\alpha$ compared to control mice receiving vehicle (Figure 3-6B). The adoptive transfer of pDCs prior to RSV infection similarly resulted in a moderate, but significant, reduction in pulmonary viral load, as evidenced by decreased live RSV titer from $280 \pm 43$ to $172 \pm 28 \mathrm{PFU} / \mathrm{g}$ of lung and a $66 \%$ reduction in relative expression of NS1 gene compared to mice receiving vehicle.

\section{IFN- $\alpha$ Treatment Prior to Neonatal RSV Infection Reduced IL-4R $\alpha$ Expression on T Helper Cells during Primary Infection}

As mentioned above, we and other groups have shown that the hallmark of the immunopathophysiology during reinfection in mice initially infected as neonates are the biased Th2 responses following reinfection in the adult. Because IFN- $\alpha$ treatment prior to neonatal RSV infection reduced these Th2-biased responses to RSV upon reinfection (86), we sought to determine if IFN- $\alpha$ treatment also changed the Th profile in the lung during primary infection (Figure 3-7). Four-day-old pups were instilled with IFN- $\alpha$ prior to RSV infection. The Th profile was measured in the lung at 6 dpi using flow cytometry.

Neonatal RSV infection induced the recruitment of Th1 cells, Th2 cells, and multifunctional Th cells in the lungs (Figure 3-7A\&B). Treatment with IFN- $\alpha$ prior to RSV infection reduced all of these Th subsets. Th1 cells declined from $0.49 \pm 0.05$ to $0.34 \pm 0.032 \%$, Th2 cells decreased from $0.057 \pm 0.006$ to $0.027 \pm 0.005 \%$, and multifunctional Th cells decreased from $0.006 \pm 0.001$ to $0.001 \pm 0.0003 \%$ of $\mathrm{CD}^{+} \mathrm{T}$ cells. In fact, the levels of these 3 Th subsets decreased to homeostatic baseline levels, as observed in the sham-infected mice (NS/Sham or IFN- $\alpha /$ Sham), despite the fact that live virus was detected in the lungs of IFN- $\alpha$-treated and RSV-infected mice (Figure 3-6).

Importantly, we have recently shown that IL-4R $\alpha$ expression on Th cells plays a central pathogenic role in the Th2-biased responses of mice initially infected as neonates (51); we therefore measured the level of IL-4R $\alpha$ on Th cells during initial RSV infection. Mice were treated with IFN- $\alpha$ prior to RSV infection and IL-4R $\alpha$ levels on pulmonary $\mathrm{CD}^{+}{ }^{+} \mathrm{T}$ cells were measured at $2 \mathrm{dpi}$, as previously published (52). Consistent with our previous findings (52), RSV infection in neonates did not change the expression of IL$4 \mathrm{R} \alpha$ on $\mathrm{CD}^{+} \mathrm{T}$, Th1, and Th2 cells (Figure 3-7C-E). Treatment with IFN- $\alpha$ significantly reduced the expression of IL-4R $\alpha$ on Th2 cells. There was no significant decrease in expression of IL-4R $\alpha$ on Th1 cells observed between IFN- $\alpha$ and vehicle-treated mice (IFN- $\alpha / \mathrm{RSV}$ vs. NS/RSV) or between IFN- $\alpha$ treated, RSV-infected mice (IFN- $\alpha / \mathrm{RSV}$ ) and sham-infected mice (NS/Sham or IFN- $\alpha /$ Sham).

Collectively, the data shown above demonstrated that IFN- $\alpha$ treatment prior to neonatal RSV infection reduced pulmonary Th cell responses and IL-4R $\alpha$ expression on Th2 cells while decreasing viral load, suggesting dual mechanisms of action. 

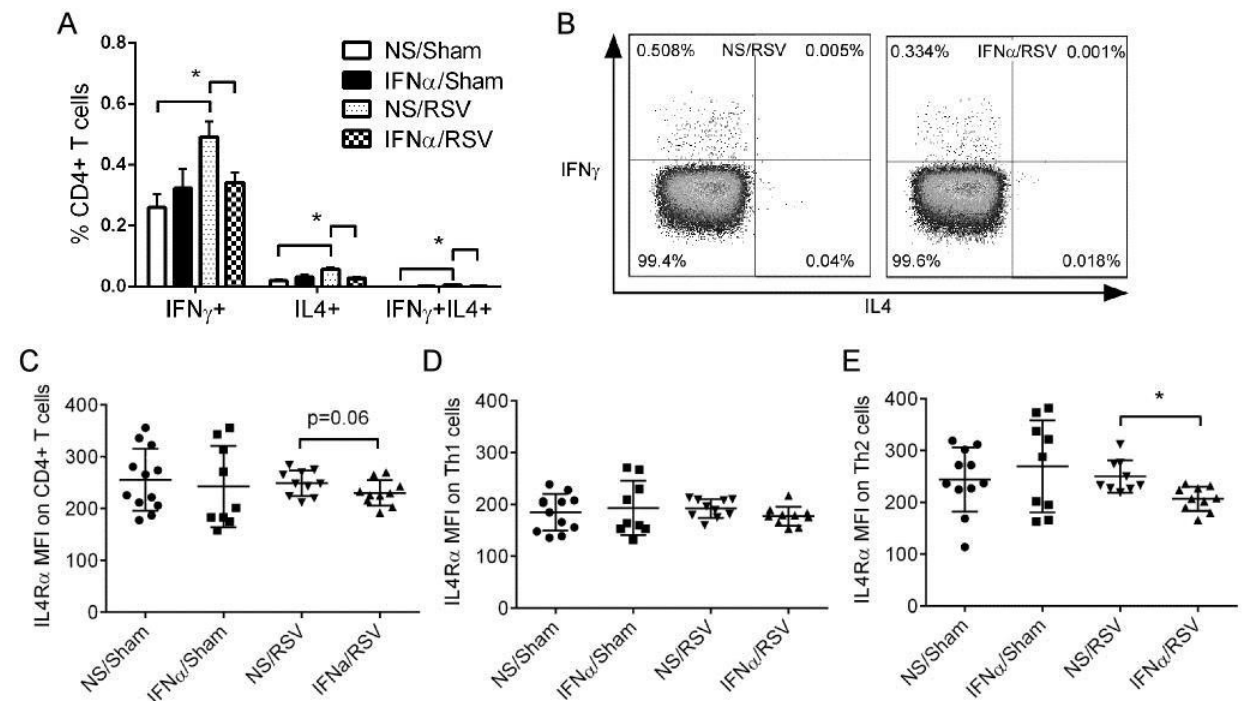

Figure 3-7. IFN- $\alpha$ treatment reduced Th responses to primary RSV infection in neonates.

Four-day-old pups were treated with IFN- $\alpha$ or vehicle at $16 \mathrm{~h}$ prior to RSV infection. Pulmonary T cell profile or IL-4R $\alpha$ expression on Th cells was measured at 6 dpi or 2 dpi, respectively. (A) Pulmonary Th profile at 6 dpi. $\mathrm{N}=5-8$ mice, ${ }^{*} p<0.05$. Data are presented as mean \pm SEM. (B) Representative flow plots of the Th profile. (C) Relative expression of IL-4R $\alpha$ on $\mathrm{CD}^{+} \mathrm{T}$ cells. (D) Relative expression of IL-4R $\alpha$ expression on Th1 cells. (E) Relative expression of IL-4R $\alpha$ on Th2 cells. $\mathrm{N}=9-12$ mice, ${ }^{*} p<0.05$.

NS/Sham: mice treated with vehicle and mock-infected; IFN- $\alpha$ /Sham: mice treated with IFN- $\alpha$ and mock-infected; NS/RSV: mice treated with vehicle and infected with RSV; IFN- $\alpha /$ RSV: mice treated with IFN- $\alpha$ and infected with RSV. Individual data are shown with mean \pm SEM. 


\section{Discussion}

Despite nearly 60 years of intense research on RSV, we still have no efficacious vaccines or therapeutics for this virus. The initial use of adult instead of neonatal animal models and the lack of knowledge of immune responses in infants are partially responsible for the slow progress. In fact, mice infected initially as neonates develop biased Th2 pulmonary immune responses upon reinfection with RSV; whereas mice initially infected as adults develop dominant Th1 responses upon reinfection with RSV. In the present study, we investigated the role of pDCs and type I IFNs in the pathogenesis of RSV using our neonatal mouse model. We showed that primary RSV infection in neonatal mice induced limited pDC and type I IFN responses compared to adult mice. We further demonstrated that intranasal instillation of recombinant IFN- $\alpha$ or the adoptive transfer of adult $\mathrm{pDCs}$ to the lungs prior to neonatal RSV infection considerably decreased immunopathophysiology during RSV reinfection, including reducing AHR, eosinophilia, mucus hyperproduction, and pulmonary Th2 responses. These data suggest that the limited $\mathrm{pDC}$ responses and type I IFN responses in neonates during primary infection permit the Th2-biased immunopathogenesis during RSV reinfection.

Although both prophylactic IFN- $\alpha$ and adoptive transfer of adult pDCs exerted similar immunomodulatory effects during RSV reinfection, there are differences in the extent of the effects between the two treatments that cannot be explained by the differences in the anti-viral properties of IFN- $\alpha$ and pDCs (i.e., pDC transfer had less of an effect on viral load than IFN- $\alpha$ treatment). These differences include: 1) IFN- $\alpha$ treatment decreased the number of eosinophils and had no effect on other cell types in the BALF during reinfection; whereas adoptive transfer of $\mathrm{pDCs}$ decreased eosinophils, monocytes, and neutrophils (Figure 3-4C vs. 3-5B) IFN- $\alpha$ treatment decreased pulmonary Th2 cells but had no effect on Th1 cells during reinfection; whereas adoptive transfer of pDCs decreased Th2 cells and increased Th1 cells in the lung (Figure 3-4A vs. 3-5C). Although not tested in, and outside of the scope of, this study, these differences might be due to properties other than the anti-viral effect of pDCs. For example, in addition to producing IFN- $\alpha$ upon viral infection, $\mathrm{pDCs}$ have been shown to acquire dendrites, upregulate MHCII and co-stimulatory molecules, and activate naïve T cells (112). Therefore, adoptively transferred adult pDCs might serve not only as a source of IFN- $\alpha$ but also as additional antigen presentation cells driving the immune response towards the Th1 arm. Interestingly, adoptive transfer of adult pDCs prior to RSV infection in the neonate appeared to be less protective during the initial infection (i.e., higher pulmonary viral load) and less beneficial during reinfection (i.e., increased AHR) than administration of IFN- $\alpha$. This phenomenon may be because the number of transferred pDCs was insufficient to overcome the neonatal immune microenvironment of the lung.

The mechanisms via which IFN- $\alpha$ treatment mitigated the Th2-biased immunopathologies during RSV reinfection in mice initially infected as neonates appear to be multifactorial. The reduction in viral load (86) undoubtedly accounts for some improvement in RSV mediated disease. Although it is difficult to dissociate the anti-viral effects of IFN- $\alpha$, our previous publication clearly demonstrated that enhanced IL-4R $\alpha$ 
expression on neonatal Th cells compared to adult Th cells plays a significant role in the development of the Th2 biased immunopathologies following RSV reinfection (52). Furthermore, reduction of IL-4R $\alpha$ on Th2 cells during primary infection prevents Th2 bias, airway hyperreactivity, mucus hyperproduction, and inflammation upon reinfection without affecting viral load (38). In line with this observation, the data presented here demonstrate that IFN- $\alpha$ treatment prior to RSV infection reduces the expression of IL$4 \mathrm{R} \alpha$ on Th2 cells (Figure 3-7E). Because IL-4R $\alpha$ levels are higher in neonates, where viral loads are lower compared to adults (55) and do not change in response to RSV infection (52), we also propose that the immunomodulatory aspects of IFN- $\alpha$ play a role in the effects observed here. Thus, we believe that both of the mechanisms of IFN- $\alpha$ action outlined above are involved in the observed protective effect.

Although IFN- $\alpha$-induced downregulation of IL-4R $\alpha$ was moderate during primary infection, the outcome of disease following reinfection was substantial (i.e., airway function is improved and pulmonary inflammation, mucus hyperproduction, and the Th2biased response was dramatically reduced). In fact, these results were strikingly similar to what we have previously published with antisense oligonucleotides to IL-4R $\alpha$ - moderate downregulation of IL-4R $\alpha$ during neonatal RSV infection completely abolished reinfection-associated airway hyperactivity and significantly decreased Th2-biased responses. We believe this phenomenon to be due to fine-tuning of IL-4R $\alpha$ signaling, which results in a rebalancing of the immune response so that Th2 cells no longer skew the immune response. This is evidenced by the primary Th response in which the ratio of Th1/Th2 is increased in IFN- $\alpha$ treated mice (IFN- $\alpha /$ RSV vs. NS/RSV: $9.230 \pm 8.230$ vs. $5.137 \pm 4.137)$.

In addition to its antiviral effects, IFN- $\alpha$ has also been shown to promote Th1 responses (113) and suppress Th2 responses (114) ex vivo. As expected in our model (Figure 3-7A) IFN- $\alpha$ treatment prior to neonatal RSV infection significantly decreased pulmonary Th2 cells. Surprisingly, pulmonary Th1 cells were reduced in IFN- $\alpha$-treated neonates following RSV infection. Most importantly, the Th cell responses to RSV in IFN- $\alpha$ treated neonatal mice were reduced to the same level as those in sham-infected animals. The reason for the decrease in pulmonary Th1 cells following RSV infection in the neonate treated with IFN- $\alpha$ is unclear (Figure 3-7A). We cannot exclude the possibility that the reduction in pulmonary viral load is responsible for the decrease in pulmonary Th1 cells in IFN- $\alpha$-treated, RSV infected neonates, but our data presented here demonstrating that IFN- $\alpha$ modulates IL-4R $\alpha$ levels during initial infection and our prior data demonstrating that modulating IL-4R $\alpha$ levels at time of initial infection in the neonate suggest that IFN- $\alpha$ also modulates Th1/Th2 balance. Thus, we believe our data support two mechanisms of IFN- $\alpha$ activity on reducing RSV-mediated disease: 1) it reduces viral load and 2) it modulates immune responses through IL-4R $\alpha$. We feel that our data are instructive for RSV vaccine design and suggest that an adjuvant capable of inducing IFN- $\alpha$ responses offers additional benefit due to its ability to modulate the neonatal immune response.

There were early attempts in late 80 s and early 90 s to test the feasibility of IFN- $\alpha$ as an RSV therapeutic. Unfortunately, the clinical trial showed that daily intramuscular 
injection of IFN- $\alpha$ into RSV-infected infants for three consecutive days did not change the overall clinical course, duration of oxygen requirement, or viral shedding; although the treatment did induce a more rapid drop of clinical score during the first three days (115). The difference between these human studies and our data in neonates may be explained by the different strategies we employed. First, in our model, IFN- $\alpha$ was instilled directly onto the mucosal surface where RSV infection naturally occurs, whereas in the human studies IFN- $\alpha$ was administered systemically. Second, in our model, IFN- $\alpha$ was instilled prior to RSV infection in the hope of preventing Th2-biased responses during reinfection, whereas in the human studies IFN- $\alpha$ was administered after RSV infection as a therapy. One very important result of this human study is that it demonstrated that the usage of IFN- $\alpha$ in infants is safe (116). In fact, RSV-infected infants ranging from two to eight months old received daily maximal 70,000 U of IFN- $\alpha$ per $\mathrm{kg}$ of body weight with no toxicity observed. One of the most intimidating difficulties in RSV vaccine or therapeutic research is that RSV is an infant disease and any intervention for infants has to be applied with considerable forethought and extreme caution. We feel that the safety of IFN- $\alpha$ in human infants and the encouraging results from our studies strongly suggests that IFN- $\alpha$ is a promising target for future RSV vaccine design due to its immunomodulatory property.

In summary, limited type I IFN and $\mathrm{pDC}$ responses in neonatal mice permit the development of Th2-biased immunopathogenesis during RSV reinfection. IFN- $\alpha$ or adoptive transfer of adult $\mathrm{pDCs}$ prior to neonatal RSV infection reduced the Th2-biased immunopathophysiologies, possibly because of their antiviral properties and by downregulating IL-4R $\alpha$ expression on Th2 cells. These observations support using an adjuvant capable of inducing IFN- $\alpha$ in future RSV vaccine strategies. 


\section{CHAPTER 4. DISCUSSION, CONCLUSION, AND PERSPECTIVE}

\section{A Role for IL-4Ra on mDCs in RSV Infection}

Our lab and others have demonstrated that RSV infection of neonates leads to Th2 biased responses, which are partly responsible for RSV pathology (52-54). Further, we have shown that downregulation of IL-4R $\alpha$ in the lung using ASO is protective against Th2-biased immunopathogenesis in neonatal mice induced by RSV (51). A significant decrease in IL-4R $\alpha$ levels on mDCs was observed in concurrence with remediation of RSV disease (51). In chapter 2, we observed elevated levels of IL-4R $\alpha$ on pulmonary $\mathrm{CD}_{1} 1 \mathrm{~b}^{+} \mathrm{mDCs}$ in neonates compared to that of adults. Deletion of IL-4R $\alpha$ on neonatal $\mathrm{CD} 11 \mathrm{c}^{+}$cells (which included $\mathrm{CD} 11 \mathrm{~b}^{+} \mathrm{mDCs}$ ) resulted in a significant reduction in $\mathrm{Th} 2$ biased responses (Th2 cells, cytokines, and eosinophils), airway hyperreactivity, and inflammation following RSV reinfection. An increase in Th1 promoting cytokine (IL-12) was seen along with the decrease in Th2 biased responses. The specific role of IL-4R $\alpha$ on neonatal $\mathrm{CD}_{11} \mathrm{~b}^{+} \mathrm{mDCs}$ in $\mathrm{Th} 2$ induction in response to RSV was demonstrated via in vitro $\mathrm{T}$ cell activation assay. Conversely, overexpressing IL-4R $\alpha$ on adult $\mathrm{CD} 11 \mathrm{~b}^{+} \mathrm{mDCs}$ and adoptive transfer of these cells into adult lungs prior to RSV infection resulted in Th2 biased responses to RSV similar to what is observed with neonatal RSV infection.

This body of work added the novel finding that differences in IL-4R $\alpha$ levels exist between mDCs at different ages. How exactly IL-4R $\alpha$ expression on $\mathrm{mDCs}$ changes with age remains to be understood. Our data suggest that elevated IL-4R $\alpha$ levels, as occurs on neonatal mDCs, inhibits the ability of these mDCs to mature and a decreased ability to produce IL-12 in response to RSV infection. Surprisingly, IL-4 treatment on BMDCs has been shown to promote IL-12 production and DCs maturation $(89,117)$. This dichotomy could be explained by the distinct roles of two types of IL-4R. While IL-4 signaling through type I IL-4R on mDCs promotes IL-12 production, IL-13 signaling through type II IL-4R has been shown to suppress it (118). Our data support the latter result because we observed high levels of IL-13, but not IL-4, and low levels of IL-12 in mice after RSV infection (119).

Our data from human infants hospitalized with RSV suggest another possible mechanism. In these data, we observed elevated IL-13 levels in nasal aspirates of children hospitalized with RSV (119). IL-13 levels positively correlated with IL-33 levels in the infants (119). IL-33 has been shown to act on mDCs and increase OX-40L expression (120). OX-40L further promotes Th2 biased responses (121) to RSV.

\section{pDC and IFN- $\alpha$ in Neonatal RSV Infection}

In chapter 3, we discovered differences in recruitment of pDCs in lungs of neonates versus adults in RSV infection. There were significantly less pulmonary pDCs and type I IFNs in neonates upon RSV infection compared to that of adults. This correlates with human data where lower amounts of type I IFNs are observed in infants 
infected with RSV (76). Treatment with recombinant type I IFN- $\alpha$ or adoptive transfer of adult pDCs into neonatal mice prior to neonatal RSV infection prevented RSV induced Th2 biased immunopathophysiology including pulmonary Th2 responses, eosinophilia, AHR, and mucus hyperproduction even after reinfection. Mechanistically, we determined that treatment with type I IFN- $\alpha$ significantly reduced RSV viral load in the lungs of mice and downregulated the levels of IL-4R $\alpha$ levels on Th2 cells.

In chapter 1, we observed also differences in IL-4R $\alpha$ expression on $\mathrm{pDCs}$ in neonates compared to that of adults. We speculate that high levels of IL-4R $\alpha$ on pDCs are responsible for a reduced type I IFN response in neonates in RSV infection. This speculation is supported by a study where IL-4 or IL-13 treatment on pDCs that signals through IL-4R $\alpha$ reduced type I IFN- $\alpha$ production (122). How exactly IL-4R $\alpha$ levels affect type I IFNs production from pDCs is yet to be studied. Presumably, higher levels of IL4R $\alpha$ signaling inhibit the IFN- $\alpha$ receptor (IFNAR) signaling that promotes type I IFN responses in pDCs.

\section{Concluding Remarks}

RSV causes significant health consequences in infant and elderly populations. Here we focused on the pulmonary immunopathology that develops in association with RSV infection in infants. Age at time of RSV infection remains a critical factor because infants who are infected are more likely to develop chronic respiratory diseases like asthma. Although epidemiological data have shown a connection between RSV infection and the development of asthma later in life, there is little in the literature establishing mechanisms for this process. The link between RSV infection during infancy and development of respiratory disease continues to be an area of investigation.

We and others have shown that mouse neonates and human infants respond with Th2 biased responses to RSV $(43,52,123)$. Our group has determined some mechanistic explanations for the Th2 biased responses to RSV (Figure 4-1) but more questions need to be addressed. Using an IL-4R $\alpha$ ASO prior to RSV infection (51), we were able to protect neonatal mice from RSV immunopathophysiology. Downregulation of IL-4R $\alpha$ in these studies occurred on $\mathrm{CD}^{+} \mathrm{T}$ cells, $\mathrm{mDCs}$, and airway epithelial cells. Recently, we discovered high levels of IL-33 in neonatal mice and human infants with severe RSV infection (119), presumably from epithelial cells. So, I hypothesize that high levels of IL4R $\alpha$ on epithelial cells promote IL-33 in neonatal mice in RSV infection. Further, IL-33 has been shown to activate OX-40L on mDCs which play an important role in Th2 biased responses (121). IL-33 also activates ILC2s to release high amounts of IL-13 in response to RSV $(119,124)$. Here, chapter 2 and chapter 3 demonstrated the role of IL-13:IL-4R $\alpha$ signaling in suppressing production of IL-12 and IFN- $\alpha$ cytokines from DCs in RSV infection. This suppression of Th1 promoting cytokines leads to Th2 biased responses following RSV infection in neonatal mice. Elevations of IL-13 and decreased IFN- $\alpha$ in nasal secretions from infants with severe RSV disease suggest that this is also occurring in humans. 


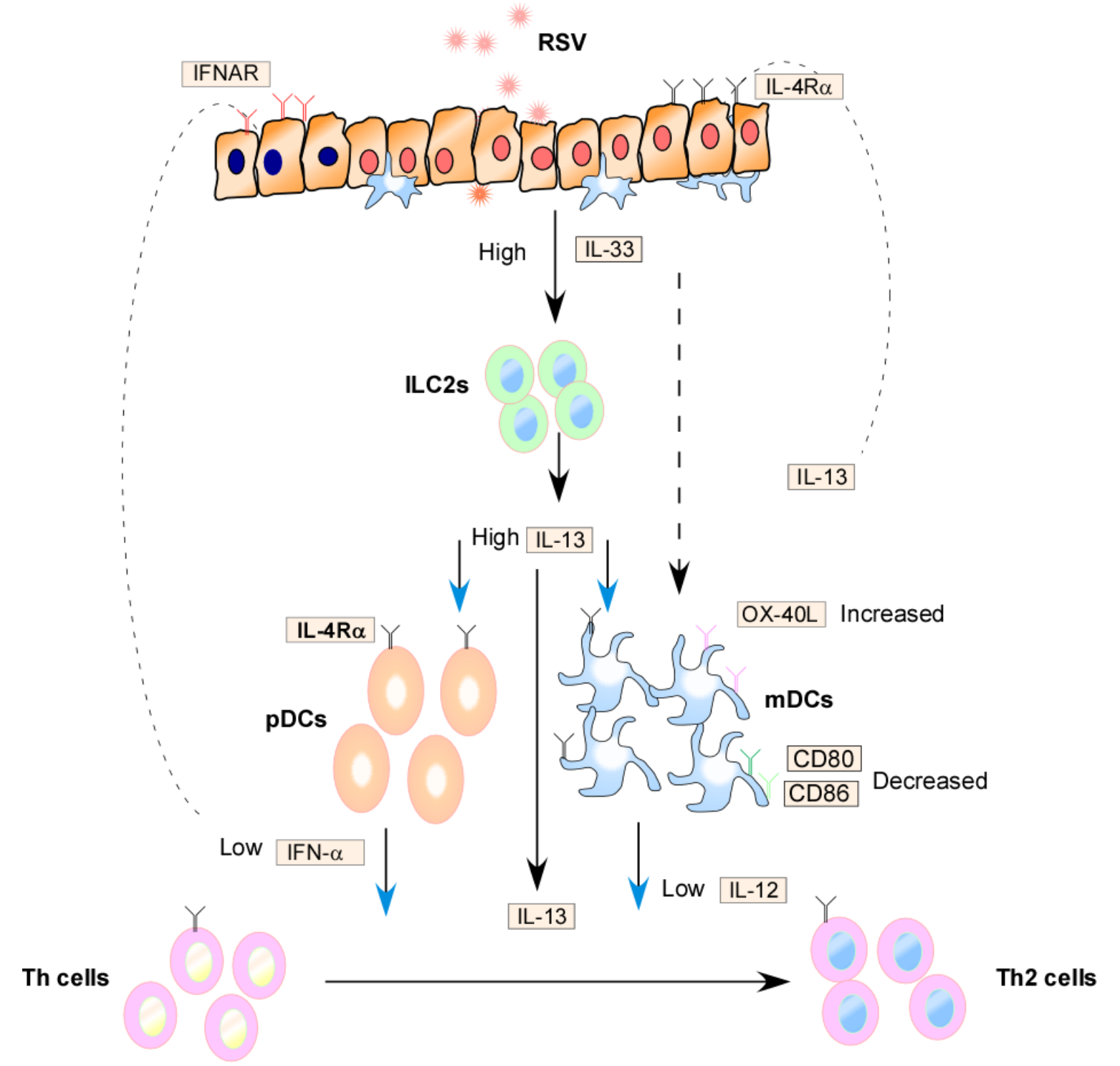

Figure 4-1. Schematic representation of immune response to RSV in neonates. RSV infection of neonatal epithelial cells releases IL-33, which activates ILC2s to produce IL-13 (122). The Th2 cytokine, IL-13 binds to IL-4R $\alpha$ on DCs allowing suppression of IL-12 and IFN- $\alpha$ production or binds to epithelial cells which result in production of more IL-33. IL-33 can also bind to OX-40L on mDCs controlling their ability to mature in response to RSV. Low levels of Th1 promoting cytokines IFN- $\alpha$ and IL-12 lead to Th2 biased responses $(128,129)$ in neonates following RSV infection. Blue arrow head denotes my own findings in this dissertation. Black arrow head represents relationships discovered by others (122). Dashed line represents unknown. 
Overall, our studies have highlighted the differences in neonatal and adult immunity to RSV including different mechanisms that are responsible for the induction of the Th2 responses in neonates. Understanding differences between neonatal and adult immunity can lead towards the development of novel therapeutics to prevent RSV induced immunopathophysiology and inform vaccine strategies. 


\section{LIST OF REFERENCES}

1. $\quad$ Blount, R. E., Jr., J. A. Morris, and R. E. Savage. 1956. Recovery of cytopathogenic agent from chimpanzees with coryza. Proc. Soc. Exp. Biol. Med. 92: 544-549.

2. Chanock, R., and L. Finberg. 1957. Recovery from infants with respiratory illness of a virus related to chimpanzee coryza agent (CCA). II. Epidemiologic aspects of infection in infants and young children. Am J Hyg 66: 291-300.

3. Hall, C. B., G. A. Weinberg, M. K. Iwane, A. K. Blumkin, K. M. Edwards, M. A. Staat, P. Auinger, M. R. Griffin, K. A. Poehling, D. Erdman, C. G. Grijalva, Y. Zhu, and P. Szilagyi. 2009. The burden of respiratory syncytial virus infection in young children. $N$ Engl J Med 360: 588-598.

4. Nair, H., D. J. Nokes, B. D. Gessner, M. Dherani, S. A. Madhi, R. J. Singleton, K. L. O'Brien, A. Roca, P. F. Wright, N. Bruce, A. Chandran, E. Theodoratou, A. Sutanto, E. R. Sedyaningsih, M. Ngama, P. K. Munywoki, C. Kartasasmita, E. A. Simoes, I. Rudan, M. W. Weber, and H. Campbell. 2010. Global burden of acute lower respiratory infections due to respiratory syncytial virus in young children: a systematic review and meta-analysis. Lancet 375: 1545-1555.

5. Lo, M. S., R. M. Brazas, and M. J. Holtzman. 2005. Respiratory syncytial virus nonstructural proteins NS1 and NS2 mediate inhibition of Stat2 expression and alpha/beta interferon responsiveness. J. Virol. 79: 9315-9319.

6. Mufson, M. A., C. Orvell, B. Rafnar, and E. Norrby. 1985. Two distinct subtypes of human respiratory syncytial virus. J. Gen. Virol. 66 ( Pt 10): 2111-2124.

7. Duvvuri, V. R., A. Granados, P. Rosenfeld, J. Bahl, A. Eshaghi, and J. B. Gubbay. 2015. Genetic diversity and evolutionary insights of respiratory syncytial virus A ON1 genotype: global and local transmission dynamics. Sci Rep 5: 14268.

8. Tripp, R. A., L. P. Jones, L. M. Haynes, H. Zheng, P. M. Murphy, and L. J. Anderson. 2001. CX3C chemokine mimicry by respiratory syncytial virus $\mathrm{G}$ glycoprotein. Nat. Immunol. 2: 732-738.

9. Collins, P. L., R. Fearns, and B. S. Graham. 2013. Respiratory syncytial virus: virology, reverse genetics, and pathogenesis of disease. Curr. Top. Microbiol. Immunol. 372: 3-38.

10. Eiland, L. S. 2009. Respiratory syncytial virus: diagnosis, treatment and prevention. J Pediatr Pharmacol Ther 14: 75-85. 
11. Feltes, T. F., A. K. Cabalka, H. C. Meissner, F. M. Piazza, D. A. Carlin, F. H. Top, Jr., E. M. Connor, H. M. Sondheimer, and G. Cardiac Synagis Study. 2003. Palivizumab prophylaxis reduces hospitalization due to respiratory syncytial virus in young children with hemodynamically significant congenital heart disease. $J$ Pediatr 143: 532-540.

12. El Saleeby, C. M., A. J. Bush, L. M. Harrison, J. A. Aitken, and J. P. Devincenzo. 2011. Respiratory syncytial virus load, viral dynamics, and disease severity in previously healthy naturally infected children. J. Infect. Dis. 204: 996-1002.

13. American Academy of Pediatrics Subcommittee on, D., and B. Management of. 2006. Diagnosis and management of bronchiolitis. Pediatrics 118: 1774-1793.

14. 1998. Palivizumab, a humanized respiratory syncytial virus monoclonal antibody, reduces hospitalization from respiratory syncytial virus infection in high-risk infants. The IMpact-RSV Study Group. Pediatrics 102: 531-537.

15. Makari, D., P. A. Checchia, and J. Devincenzo. 2014. Rationale for full-season dosing for passive antibody prophylaxis of respiratory syncytial virus. Hum Vaccin Immunother 10: 607-614.

16. DeVincenzo, J. P. 2012. The promise, pitfalls and progress of RNA-interferencebased antiviral therapy for respiratory viruses. Antivir Ther 17: 213-225.

17. DeVincenzo, J. P., M. W. McClure, J. A. Symons, H. Fathi, C. Westland, S. Chanda, R. Lambkin-Williams, P. Smith, Q. Zhang, L. Beigelman, L. M. Blatt, and J. Fry. 2015. Activity of Oral ALS-008176 in a Respiratory Syncytial Virus Challenge Study. N Engl J Med 373: 2048-2058.

18. Leader, S., and K. Kohlhase. 2003. Recent trends in severe respiratory syncytial virus (RSV) among US infants, 1997 to 2000. J Pediatr 143: S127-132.

19. Aberle, J. H., S. W. Aberle, E. Pracher, H. P. Hutter, M. Kundi, and T. PopowKraupp. 2005. Single versus dual respiratory virus infections in hospitalized infants: impact on clinical course of disease and interferon-gamma response. Pediatr. Infect. Dis. J. 24: 605-610.

20. Falsey, A. R., P. A. Hennessey, M. A. Formica, C. Cox, and E. E. Walsh. 2005. Respiratory syncytial virus infection in elderly and high-risk adults. $N$ Engl $\mathrm{J}$ Med 352: $1749-1759$.

21. Falsey, A. R., and E. E. Walsh. 2005. Respiratory syncytial virus infection in elderly adults. Drugs Aging 22: 577-587.

22. Murray, J., A. Bottle, M. Sharland, N. Modi, P. Aylin, A. Majeed, S. Saxena, and G. Medicines for Neonates Investigator. 2014. Risk factors for hospital admission 
with RSV bronchiolitis in England: a population-based birth cohort study. PLoS One 9: e89186.

23. Garcia, C. G., R. Bhore, A. Soriano-Fallas, M. Trost, R. Chason, O. Ramilo, and A. Mejias. 2010. Risk factors in children hospitalized with RSV bronchiolitis versus non-RSV bronchiolitis. Pediatrics 126: e1453-1460.

24. Miyairi, I., and J. P. DeVincenzo. 2008. Human genetic factors and respiratory syncytial virus disease severity. Clin. Microbiol. Rev. 21: 686-703.

25. Mansbach, J. M., P. A. Piedra, M. D. Stevenson, A. F. Sullivan, T. F. Forgey, S. Clark, J. A. Espinola, C. A. Camargo, Jr., and M.-. Investigators. 2012.

Prospective multicenter study of children with bronchiolitis requiring mechanical ventilation. Pediatrics 130: e492-500.

26. Simoes, E. A. 2003. Environmental and demographic risk factors for respiratory syncytial virus lower respiratory tract disease. J Pediatr 143: S118-126.

27. Ferolla, F. M., D. R. Hijano, P. L. Acosta, A. Rodriguez, K. Duenas, A. Sancilio, E. Barboza, A. Caria, G. F. Gago, R. E. Almeida, L. Castro, C. Pozzolo, M. V. Martinez, L. A. Grimaldi, B. Rebec, M. Calvo, J. Henrichsen, C. Nocito, M. Gonzalez, G. Barbero, J. V. Losada, M. T. Caballero, V. Zurankovas, M. Raggio, G. Schavlovsky, A. Kobylarz, V. Wimmenauer, J. Bugna, J. V. Williams, G. Sastre, E. Flamenco, A. R. Perez, F. Ferrero, R. Libster, C. G. Grijalva, and F. P. Polack. 2013. Macronutrients during pregnancy and life-threatening respiratory syncytial virus infections in children. Am. J. Respir. Crit. Care Med. 187: 983990.

28. Belderbos, M. E., M. L. Houben, B. Wilbrink, E. Lentjes, E. M. Bloemen, J. L. Kimpen, M. Rovers, and L. Bont. 2011. Cord blood vitamin D deficiency is associated with respiratory syncytial virus bronchiolitis. Pediatrics 127: e15131520.

29. Levy, O. 2007. Innate immunity of the newborn: basic mechanisms and clinical correlates. Nat. Rev. Immunol. 7: 379-390.

30. Jones, C. A., J. A. Holloway, and J. O. Warner. 2002. Phenotype of fetal monocytes and B lymphocytes during the third trimester of pregnancy. J. Reprod. Immunol. 56: 45-60.

31. Levy, O., K. A. Zarember, R. M. Roy, C. Cywes, P. J. Godowski, and M. R. Wessels. 2004. Selective impairment of TLR-mediated innate immunity in human newborns: neonatal blood plasma reduces monocyte TNF-alpha induction by bacterial lipopeptides, lipopolysaccharide, and imiquimod, but preserves the response to R-848. J. Immunol. 173: 4627-4634. 
32. Angelone, D. F., M. R. Wessels, M. Coughlin, E. E. Suter, P. Valentini, L. A. Kalish, and O. Levy. 2006. Innate immunity of the human newborn is polarized toward a high ratio of IL-6/TNF-alpha production in vitro and in vivo. Pediatr Res 60: 205-209.

33. Ma, L., J. Ceuppens, A. Kasran, M. Delforge, M. Boogaerts, and P. Vandenberghe. 2007. Immature and mature monocyte-derived dendritic cells in myelodysplastic syndromes of subtypes refractory anemia or refractory anemia with ringed sideroblasts display an altered cytokine profile. Leuk Res 31: 13731382.

34. Chelvarajan, R. L., S. M. Collins, I. E. Doubinskaia, S. Goes, J. Van Willigen, D. Flanagan, W. J. De Villiers, J. S. Bryson, and S. Bondada. 2004. Defective macrophage function in neonates and its impact on unresponsiveness of neonates to polysaccharide antigens. J Leukoc Biol 75: 982-994.

35. Siegrist, C. A. 2001. Neonatal and early life vaccinology. Vaccine 19: 3331-3346.

36. Powell, T. J., Jr., and J. W. Streilein. 1990. Neonatal tolerance induction by class II alloantigens activates IL-4-secreting, tolerogen-responsive T cells. J. Immunol. 144: 854-859.

37. Hebel, K., S. Weinert, B. Kuropka, J. Knolle, B. Kosak, G. Jorch, C. Arens, E. Krause, R. C. Braun-Dullaeus, and M. C. Brunner-Weinzierl. 2014. CD4+ T cells from human neonates and infants are poised spontaneously to run a nonclassical IL-4 program. J. Immunol. 192: 5160-5170.

38. You, D., M. Ripple, S. Balakrishna, D. Troxclair, D. Sandquist, L. Ding, T. A. Ahlert, and S. A. Cormier. 2008. Inchoate CD8+ T cell responses in neonatal mice permit influenza-induced persistent pulmonary dysfunction. J. Immunol. 181: 3486-3494.

39. Forsthuber, T., H. C. Yip, and P. V. Lehmann. 1996. Induction of TH1 and TH2 immunity in neonatal mice. Science 271: 1728-1730.

40. Vanden Eijnden, S., S. Goriely, D. De Wit, M. Goldman, and F. Willems. 2006. Preferential production of the IL-12(p40)/IL-23(p19) heterodimer by dendritic cells from human newborns. Eur. J. Immunol. 36: 21-26.

41. Yoshimoto, M., M. C. Yoder, P. Guevara, and B. Adkins. 2013. The murine Th2 locus undergoes epigenetic modification in the thymus during fetal and postnatal ontogeny. PLoS One 8: e51587.

42. Roman, M., W. J. Calhoun, K. L. Hinton, L. F. Avendano, V. Simon, A. M. Escobar, A. Gaggero, and P. V. Diaz. 1997. Respiratory syncytial virus infection 
in infants is associated with predominant Th-2-like response. Am. J. Respir. Crit. Care Med. 156: 190-195.

43. Legg, J. P., I. R. Hussain, J. A. Warner, S. L. Johnston, and J. O. Warner. 2003. Type 1 and type 2 cytokine imbalance in acute respiratory syncytial virus bronchiolitis. Am. J. Respir. Crit. Care Med. 168: 633-639.

44. Sung, R. Y., S. H. Hui, C. K. Wong, C. W. Lam, and J. Yin. 2001. A comparison of cytokine responses in respiratory syncytial virus and influenza A infections in infants. Eur. J. Pediatr. 160: 117-122.

45. Castro, M., T. Schweiger, H. Yin-Declue, T. P. Ramkumar, C. Christie, J. Zheng, R. Cohen, K. B. Schechtman, R. Strunk, and L. B. Bacharier. 2008. Cytokine response after severe respiratory syncytial virus bronchiolitis in early life. $J$. Allergy Clin. Immunol. 122: 726-733 e723.

46. Kim, H. W., J. G. Canchola, C. D. Brandt, G. Pyles, R. M. Chanock, K. Jensen, and R. H. Parrott. 1969. Respiratory syncytial virus disease in infants despite prior administration of antigenic inactivated vaccine. Am. J. Epidemiol. 89: 422-434.

47. Clyde, W. A., Jr. 1980. Experimental models for study of common respiratory viruses. Environ. Health Perspect. 35: 107-112.

48. Piazza, F. M., S. A. Johnson, M. E. Darnell, D. D. Porter, V. G. Hemming, and G. A. Prince. 1993. Bovine respiratory syncytial virus protects cotton rats against human respiratory syncytial virus infection. J. Virol. 67: 1503-1510.

49. Wu, P., W. D. Dupont, M. R. Griffin, K. N. Carroll, E. F. Mitchel, T. Gebretsadik, and T. V. Hartert. 2008. Evidence of a causal role of winter virus infection during infancy in early childhood asthma. Am. J. Respir. Crit. Care Med. 178: 11231129.

50. Sigurs, N., F. Aljassim, B. Kjellman, P. D. Robinson, F. Sigurbergsson, R. Bjarnason, and P. M. Gustafsson. 2010. Asthma and allergy patterns over 18 years after severe RSV bronchiolitis in the first year of life. Thorax 65: 10451052.

51. Ripple, M. J., D. You, S. Honnegowda, J. D. Giaimo, A. B. Sewell, D. M. Becnel, and S. A. Cormier. 2010. Immunomodulation with IL-4R alpha antisense oligonucleotide prevents respiratory syncytial virus-mediated pulmonary disease. J. Immunol. 185: 4804-4811.

52. You, D., N. Marr, J. Saravia, B. Shrestha, G. I. Lee, S. E. Turvey, F. Brombacher, D. R. Herbert, and S. A. Cormier. 2013. IL-4Ralpha on CD4+ T cells plays a pathogenic role in respiratory syncytial virus reinfection in mice infected initially as neonates. J Leukoc Biol 93: 933-942. 
53. Dakhama, A., J. W. Park, C. Taube, A. Joetham, A. Balhorn, N. Miyahara, K. Takeda, and E. W. Gelfand. 2005. The enhancement or prevention of airway hyperresponsiveness during reinfection with respiratory syncytial virus is critically dependent on the age at first infection and IL-13 production. J. Immunol. 175: 1876-1883.

54. Culley, F. J., J. Pollott, and P. J. Openshaw. 2002. Age at first viral infection determines the pattern of $\mathrm{T}$ cell-mediated disease during reinfection in adulthood. J. Exp. Med. 196: 1381-1386.

55. Ruckwardt, T. J., A. M. Malloy, E. Gostick, D. A. Price, P. Dash, J. L. McClaren, P. G. Thomas, and B. S. Graham. 2011. Neonatal CD8 T-cell hierarchy is distinct from adults and is influenced by intrinsic $\mathrm{T}$ cell properties in respiratory syncytial virus infected mice. PLoS Pathog 7: e1002377.

56. Srinivasa, B. T., K. H. Restori, J. Shan, L. Cyr, L. Xing, S. Lee, B. J. Ward, and E. D. Fixman. 2017. STAT6 inhibitory peptide given during RSV infection of neonatal mice reduces exacerbated airway responses upon adult reinfection. $J$ Leukoc Biol 101: 519-529.

57. You, D., J. Saravia, D. Siefker, B. Shrestha, and S. A. Cormier. 2015. Crawling with Virus: Translational Insights from a Neonatal Mouse Model on the Pathogenesis of Respiratory Syncytial Virus in Infants. J. Virol. 90: 2-4.

58. Lukacs, N. W., M. L. Moore, B. D. Rudd, A. A. Berlin, R. D. Collins, S. J. Olson, S. B. Ho, and R. S. Peebles, Jr. 2006. Differential immune responses and pulmonary pathophysiology are induced by two different strains of respiratory syncytial virus. Am J Pathol 169: 977-986.

59. Stokes, K. L., M. H. Chi, K. Sakamoto, D. C. Newcomb, M. G. Currier, M. M. Huckabee, S. Lee, K. Goleniewska, C. Pretto, J. V. Williams, A. Hotard, T. P. Sherrill, R. S. Peebles, Jr., and M. L. Moore. 2011. Differential pathogenesis of respiratory syncytial virus clinical isolates in BALB/c mice. J. Virol. 85: 57825793.

60. You, D., D. T. Siefker, B. Shrestha, J. Saravia, and S. A. Cormier. 2015. Building a better neonatal mouse model to understand infant respiratory syncytial virus disease. Respir Res 16: 91.

61. Stein, R. T., D. Sherrill, W. J. Morgan, C. J. Holberg, M. Halonen, L. M. Taussig, A. L. Wright, and F. D. Martinez. 1999. Respiratory syncytial virus in early life and risk of wheeze and allergy by age 13 years. Lancet 354: 541-545. 
62. Piippo-Savolainen, E., S. Remes, S. Kannisto, K. Korhonen, and M. Korppi. 2004. Asthma and lung function 20 years after wheezing in infancy: results from a prospective follow-up study. Arch. Pediatr. Adolesc. Med. 158: 1070-1076.

63. Fischer, J. E., J. E. Johnson, R. K. Kuli-Zade, T. R. Johnson, S. Aung, R. A. Parker, and B. S. Graham. 1997. Overexpression of interleukin-4 delays virus clearance in mice infected with respiratory syncytial virus. J. Virol. 71: 86728677.

64. Stone, K. D., C. Prussin, and D. D. Metcalfe. 2010. IgE, mast cells, basophils, and eosinophils. J. Allergy Clin. Immunol. 125: S73-80.

65. Elias, J. A., Z. Zhu, G. Chupp, and R. J. Homer. 1999. Airway remodeling in asthma. J. Clin. Invest. 104: 1001-1006.

66. Wynn, T. A. 2004. Fibrotic disease and the T(H)1/T(H)2 paradigm. Nat. Rev. Immunol. 4: 583-594.

67. Plantinga, M., M. Guilliams, M. Vanheerswynghels, K. Deswarte, F. BrancoMadeira, W. Toussaint, L. Vanhoutte, K. Neyt, N. Killeen, B. Malissen, H. Hammad, and B. N. Lambrecht. 2013. Conventional and monocyte-derived $\mathrm{CD} 11 \mathrm{~b}(+)$ dendritic cells initiate and maintain T helper 2 cell-mediated immunity to house dust mite allergen. Immunity 38: 322-335.

68. Neyt, K., and B. N. Lambrecht. 2013. The role of lung dendritic cell subsets in immunity to respiratory viruses. Immunol. Rev. 255: 57-67.

69. Blanco, P., A. K. Palucka, V. Pascual, and J. Banchereau. 2008. Dendritic cells and cytokines in human inflammatory and autoimmune diseases. Cytokine Growth Factor Rev. 19: 41-52.

70. McColl, S. R. 2002. Chemokines and dendritic cells: a crucial alliance. Immunol. Cell Biol. 80: 489-496.

71. Dakic, A., Q. X. Shao, A. D'Amico, M. O'Keeffe, W. F. Chen, K. Shortman, and L. Wu. 2004. Development of the dendritic cell system during mouse ontogeny. $J$. Immunol. 172: 1018-1027.

72. Kovarik, J., P. Bozzotti, L. Love-Homan, M. Pihlgren, H. L. Davis, P. H. Lambert, A. M. Krieg, and C. A. Siegrist. 1999. CpG oligodeoxynucleotides can circumvent the Th2 polarization of neonatal responses to vaccines but may fail to fully redirect Th2 responses established by neonatal priming. J. Immunol. 162: 1611-1617.

73. van der Sande, M. A., I. M. Kidd, T. Goetghebuer, R. A. Martynoga, A. Magnusen, S. Allen, M. W. Weber, K. L. Fielding, A. Marchant, and H. C. 
Whittle. 2002. Severe respiratory syncytial virus infection in early life is associated with increased type 2 cytokine production in Gambian children. Clin. Exp. Allergy 32: 1430-1435.

74. Siegal, F. P., N. Kadowaki, M. Shodell, P. A. Fitzgerald-Bocarsly, K. Shah, S. Ho, S. Antonenko, and Y. J. Liu. 1999. The nature of the principal type 1 interferon-producing cells in human blood. Science 284: 1835-1837.

75. Smit, J. J., B. D. Rudd, and N. W. Lukacs. 2006. Plasmacytoid dendritic cells inhibit pulmonary immunopathology and promote clearance of respiratory syncytial virus. J. Exp. Med. 203: 1153-1159.

76. McIntosh, K. 1978. Interferon in nasal secretions from infants with viral respiratory tract infections. J Pediatr 93: 33-36.

77. Sinigaglia, F., D. D'Ambrosio, and L. Rogge. 1999. Type I interferons and the Th1/Th2 paradigm. Dev. Comp. Immunol. 23: 657-663.

78. Schwarze, J., E. Hamelmann, K. L. Bradley, K. Takeda, and E. W. Gelfand. 1997. Respiratory syncytial virus infection results in airway hyperresponsiveness and enhanced airway sensitization to allergen. J. Clin. Invest. 100: 226-233.

79. Hoebee, B., E. Rietveld, L. Bont, M. Oosten, H. M. Hodemaekers, N. J. Nagelkerke, H. J. Neijens, J. L. Kimpen, and T. G. Kimman. 2003. Association of severe respiratory syncytial virus bronchiolitis with interleukin-4 and interleukin4 receptor alpha polymorphisms. J. Infect. Dis. 187: 2-11.

80. Scheinman, E. J., and O. Avni. 2009. Transcriptional regulation of GATA3 in T helper cells by the integrated activities of transcription factors downstream of the interleukin-4 receptor and T cell receptor. J. Biol. Chem. 284: 3037-3048.

81. Boeck, K. D. 1996. Respiratory syncytial virus bronchiolitis: clinical aspects and epidemiology. Monaldi Arch Chest Dis 51: 210-213.

82. Sigurs, N., P. M. Gustafsson, R. Bjarnason, F. Lundberg, S. Schmidt, F. Sigurbergsson, and B. Kjellman. 2005. Severe respiratory syncytial virus bronchiolitis in infancy and asthma and allergy at age 13. Am. J. Respir. Crit. Care Med. 171: 137-141.

83. Roman, M., W. J. Calhoun, K. L. Hinton, L. F. Avendano, V. Simon, A. M. Escobar, A. Gaggero, and P. V. Diaz. 1997. Respiratory syncytial virus infection in infants is associated with predominant Th-2-like response. Am. J. Respir. Crit. Care Med. 156: 190-195.

84. Steinman, R. M. 1991. The dendritic cell system and its role in immunogenicity. Annu. Rev. Immunol. 9: 271-296. 
85. Hunt, D. W., H. I. Huppertz, H. J. Jiang, and R. E. Petty. 1994. Studies of human cord blood dendritic cells: evidence for functional immaturity. Blood 84: 43334343.

86. Cormier, S. A., B. Shrestha, J. Saravia, G. I. Lee, L. Shen, J. P. DeVincenzo, Y. I. Kim, and D. You. 2014. Limited type I interferons and plasmacytoid dendritic cells during neonatal respiratory syncytial virus infection permit immunopathogenesis upon reinfection. J. Virol. 88: 9350-9360.

87. Marr, N., T. I. Wang, S. H. Kam, Y. S. Hu, A. A. Sharma, A. Lam, J. Markowski, A. Solimano, P. M. Lavoie, and S. E. Turvey. 2014. Attenuation of respiratory syncytial virus-induced and RIG-I-dependent type I IFN responses in human neonates and very young children. J. Immunol. 192: 948-957.

88. Cormier, S. A., D. You, and S. Honnegowda. 2010. The use of a neonatal mouse model to study respiratory syncytial virus infections. Expert Rev Anti Infect Ther 8: 1371-1380.

89. Hurdayal, R., N. E. Nieuwenhuizen, M. Revaz-Breton, L. Smith, J. C. Hoving, S. P. Parihar, B. Reizis, and F. Brombacher. 2013. Deletion of IL-4 receptor alpha on dendritic cells renders BALB/c mice hypersusceptible to Leishmania major infection. PLoS Pathog 9: e1003699.

90. Wang, P., P. Thevenot, J. Saravia, T. Ahlert, and S. A. Cormier. 2011. Radicalcontaining particles activate dendritic cells and enhance Th17 inflammation in a mouse model of asthma. Am J Respir Cell Mol Biol 45: 977-983.

91. Boukhvalova, M. S., K. C. Yim, G. A. Prince, and J. C. Blanco. 2010. Methods for monitoring dynamics of pulmonary RSV replication by viral culture and by real-time reverse transcription-PCR in vivo: Detection of abortive viral replication. Curr Protoc Cell Biol Chapter 26: Unit26 26.

92. Ptaschinski, C., S. Mukherjee, M. L. Moore, M. Albert, K. Helin, S. L. Kunkel, and N. W. Lukacs. 2015. RSV-Induced H3K4 Demethylase KDM5B Leads to Regulation of Dendritic Cell-Derived Innate Cytokines and Exacerbates Pathogenesis In Vivo. PLoS Pathog 11: e1004978.

93. Howard, T. D., G. H. Koppelman, J. Xu, S. L. Zheng, D. S. Postma, D. A. Meyers, and E. R. Bleecker. 2002. Gene-gene interaction in asthma: IL4RA and IL13 in a Dutch population with asthma. Am. J. Hum. Genet. 70: 230-236.

94. Ruckwardt, T. J., A. M. Malloy, K. M. Morabito, and B. S. Graham. 2014. Quantitative and qualitative deficits in neonatal lung-migratory dendritic cells impact the generation of the CD8+ T cell response. PLoS Pathog 10: e1003934. 
95. Murphy, E., K. Shibuya, N. Hosken, P. Openshaw, V. Maino, K. Davis, K. Murphy, and A. O'Garra. 1996. Reversibility of T helper 1 and 2 populations is lost after long-term stimulation. J. Exp. Med. 183: 901-913.

96. Paliard, X., R. de Waal Malefijt, H. Yssel, D. Blanchard, I. Chretien, J. Abrams, J. de Vries, and H. Spits. 1988. Simultaneous production of IL-2, IL-4, and IFNgamma by activated human CD4+ and CD8+ T cell clones. J. Immunol. 141: 849855.

97. Peine, M., S. Rausch, C. Helmstetter, A. Frohlich, A. N. Hegazy, A. A. Kuhl, C. G. Grevelding, T. Hofer, S. Hartmann, and M. Lohning. 2013. Stable Tbet(+)GATA-3(+) Th1/Th2 hybrid cells arise in vivo, can develop directly from naive precursors, and limit immunopathologic inflammation. PLoS Biol. 11: e1001633.

98. Tekkanat, K. K., H. F. Maassab, D. S. Cho, J. J. Lai, A. John, A. Berlin, M. H. Kaplan, and N. W. Lukacs. 2001. IL-13-induced airway hyperreactivity during respiratory syncytial virus infection is STAT6 dependent. J. Immunol. 166: 35423548.

99. Cabanas, C., and F. Sanchez-Madrid. 1999. CD11c (leukocyte integrin CR4 alpha subunit). J Biol Regul Homeost Agents 13: 134-136.

100. Muller, U., W. Stenzel, D. Piehler, A. Grahnert, M. Protschka, G. Kohler, O. Frey, J. Held, T. Richter, M. Eschke, T. Kamradt, F. Brombacher, and G. Alber. 2013. Abrogation of IL-4 receptor-alpha-dependent alternatively activated macrophages is sufficient to confer resistance against pulmonary cryptococcosis despite an ongoing $\mathrm{T}(\mathrm{h}) 2$ response. Int. Immunol. 25: 459-470.

101. Hornung, V., J. Schlender, M. Guenthner-Biller, S. Rothenfusser, S. Endres, K. K. Conzelmann, and G. Hartmann. 2004. Replication-dependent potent IFN-alpha induction in human plasmacytoid dendritic cells by a single-stranded RNA virus. J. Immunol. 173: 5935-5943.

102. Johnson, T. R., C. N. Johnson, K. S. Corbett, G. C. Edwards, and B. S. Graham. 2011. Primary human $\mathrm{mDC} 1, \mathrm{mDC} 2$, and $\mathrm{pDC}$ dendritic cells are differentially infected and activated by respiratory syncytial virus. PLoS One 6: e16458.

103. Boogaard, I., M. van Oosten, L. S. van Rijt, F. Muskens, T. G. Kimman, B. N. Lambrecht, and A. M. Buisman. 2007. Respiratory syncytial virus differentially activates murine myeloid and plasmacytoid dendritic cells. Immunology 122: 6572.

104. Smit, J. J., D. M. Lindell, L. Boon, M. Kool, B. N. Lambrecht, and N. W. Lukacs. 2008. The balance between plasmacytoid DC versus conventional DC determines pulmonary immunity to virus infections. PLoS One 3: e1720. 
105. Jewell, N. A., N. Vaghefi, S. E. Mertz, P. Akter, R. S. Peebles, Jr., L. O. Bakaletz, R. K. Durbin, E. Flano, and J. E. Durbin. 2007. Differential type I interferon induction by respiratory syncytial virus and influenza a virus in vivo. J. Virol. 81: 9790-9800.

106. Guerrero-Plata, A., S. Baron, J. S. Poast, P. A. Adegboyega, A. Casola, and R. P. Garofalo. 2005. Activity and regulation of alpha interferon in respiratory syncytial virus and human metapneumovirus experimental infections. J. Virol. 79: 1019010199.

107. Gill, M. A., A. K. Palucka, T. Barton, F. Ghaffar, H. Jafri, J. Banchereau, and O. Ramilo. 2005. Mobilization of plasmacytoid and myeloid dendritic cells to mucosal sites in children with respiratory syncytial virus and other viral respiratory infections. J. Infect. Dis. 191: 1105-1115.

108. McKimm-Breschkin, J. L. 2004. A simplified plaque assay for respiratory syncytial virus--direct visualization of plaques without immunostaining. $J$ Virol Methods 120: 113-117.

109. Spann, K. M., K. C. Tran, B. Chi, R. L. Rabin, and P. L. Collins. 2004. Suppression of the induction of alpha, beta, and lambda interferons by the NS1 and NS2 proteins of human respiratory syncytial virus in human epithelial cells and macrophages [corrected]. J. Virol. 78: 4363-4369.

110. Zucchini, N., G. Bessou, S. H. Robbins, L. Chasson, A. Raper, P. R. Crocker, and M. Dalod. 2008. Individual plasmacytoid dendritic cells are major contributors to the production of multiple innate cytokines in an organ-specific manner during viral infection. Int. Immunol. 20: 45-56.

111. Asselin-Paturel, C., A. Boonstra, M. Dalod, I. Durand, N. Yessaad, C. DezutterDambuyant, A. Vicari, A. O'Garra, C. Biron, F. Briere, and G. Trinchieri. 2001. Mouse type I IFN-producing cells are immature APCs with plasmacytoid morphology. Nat. Immunol. 2: 1144-1150.

112. Villadangos, J. A., and L. Young. 2008. Antigen-presentation properties of plasmacytoid dendritic cells. Immunity 29: 352-361.

113. Brinkmann, V., T. Geiger, S. Alkan, and C. H. Heusser. 1993. Interferon alpha increases the frequency of interferon gamma-producing human CD4+ T cells. $J$. Exp. Med. 178: 1655-1663.

114. Pene, J., F. Rousset, F. Briere, I. Chretien, J. Y. Bonnefoy, H. Spits, T. Yokota, N. Arai, K. Arai, J. Banchereau, and et al. 1988. IgE production by normal human lymphocytes is induced by interleukin 4 and suppressed by interferons gamma and alpha and prostaglandin E2. Proc Natl Acad Sci U S A 85: 6880-6884. 
115. Sung, R. Y., J. Yin, S. J. Oppenheimer, J. S. Tam, and J. Lau. 1993. Treatment of respiratory syncytial virus infection with recombinant interferon alfa-2a. Arch. Dis. Child. 69: 440-442.

116. Portnoy, J., R. Hicks, F. Pacheco, and L. Olson. 1988. Pilot study of recombinant interferon alpha-2a for treatment of infants with bronchiolitis induced by respiratory syncytial virus. Antimicrob. Agents Chemother. 32: 589-591.

117. Cook, P. C., L. H. Jones, S. J. Jenkins, T. A. Wynn, J. E. Allen, and A. S. MacDonald. 2012. Alternatively activated dendritic cells regulate CD4+ T-cell polarization in vitro and in vivo. Proc Natl Acad Sci U S A 109: 9977-9982.

118. Lutz, M. B., M. Schnare, M. Menges, S. Rossner, M. Rollinghoff, G. Schuler, and A. Gessner. 2002. Differential functions of IL-4 receptor types I and II for dendritic cell maturation and IL-12 production and their dependency on GM-CSF. J. Immunol. 169: 3574-3580.

119. Saravia, J., D. You, B. Shrestha, S. Jaligama, D. Siefker, G. I. Lee, J. N. Harding, T. L. Jones, C. Rovnaghi, B. Bagga, J. P. DeVincenzo, and S. A. Cormier. 2015. Respiratory Syncytial Virus Disease Is Mediated by Age-Variable IL-33. PLoS Pathog 11: e1005217.

120. Besnard, A. G., D. Togbe, N. Guillou, F. Erard, V. Quesniaux, and B. Ryffel. 2011. IL-33-activated dendritic cells are critical for allergic airway inflammation. Eur. J. Immunol. 41: 1675-1686.

121. Murakami-Satsutani, N., T. Ito, T. Nakanishi, N. Inagaki, A. Tanaka, P. T. Vien, K. Kibata, M. Inaba, and S. Nomura. 2014. IL-33 promotes the induction and maintenance of Th2 immune responses by enhancing the function of OX40 ligand. Allergol Int 63: 443-455.

122. Tel, J., R. Torensma, C. G. Figdor, and I. J. de Vries. 2011. IL-4 and IL-13 alter plasmacytoid dendritic cell responsiveness to CpG DNA and herpes simplex virus-1. J Invest Dermatol 131: 900-906.

123. You, D., D. Becnel, K. Wang, M. Ripple, M. Daly, and S. A. Cormier. 2006. Exposure of neonates to respiratory syncytial virus is critical in determining subsequent airway response in adults. Respir Res 7: 107.

124. Stier, M. T., M. H. Bloodworth, S. Toki, D. C. Newcomb, K. Goleniewska, K. L. Boyd, M. Quitalig, A. L. Hotard, M. L. Moore, T. V. Hartert, B. Zhou, A. N. McKenzie, and R. S. Peebles, Jr. 2016. Respiratory syncytial virus infection activates IL-13-producing group 2 innate lymphoid cells through thymic stromal lymphopoietin. J. Allergy Clin. Immunol. 138: 814-824 e811 


\section{VITA}

Bishwas Shrestha was born in 1988 in Syangja, Nepal. He graduated with Bachelor of Sciences with a major in biology and minor in chemistry with honors from University of New Orleans, New Orleans in 2008. He started his doctoral program at Louisiana State University Health Science Center in New Orleans in 2012. Then, he moved to University of Tennessee Health Science Center in Memphis with his mentor to complete his doctoral degree in Biomedical Sciences. He graduated with Doctor of Philosophy in 2017 with a concentration in Microbiology, Immunology, and Biochemistry. 